BARBARA SCAVONE BELLEM DE LIMA

\title{
PARTicipaÇÃo Democrática no Controle de CONSTITUCIONALIDADE BRASILEIRO
}

\author{
DISSERTAÇÃO DE MESTRADO
}

FACULDADE DE DIREITO DA UNIVERSIDADE DE SÃO PAULO

SÃO PAULO 


\title{
Participação Democrática no Controle de CONSTITUCIONALIDADE BRASILEIRO
}

\author{
Dissertação apresentada como requisito parcial para a \\ obtenção de grau de Mestre em Direito pelo Programa de \\ Pós-Graduação da Faculdade de Direito da Universidade de \\ São Paulo (USP) \\ Área de Concentração: Direito do Estado \\ Orientadora: Profa. Dra. Fernanda Dias Menezes de Almeida
}

FACULDADE DE DIREITO DA UNIVERSIDADE DE SÃo PAULO

SÃo PAULO 
BANCA EXAMINADORA: 
"Em quase todas (talvez todas) as organizações, por toda parte, há algum espaço para alguma democracia. Em quase todos os países democráticos há bastante espaço para mais democracia.” (Robert Dahl) 
Para meus pais, meus irmãos e Icaro. 


\section{Agradecimentos}

À minha orientadora, Fernanda Dias Menezes de Almeida, agradeço a confiança em mim depositada ao aceitar-me no programa de pós-graduação, a orientação em todos os momentos do trabalho, a disponibilidade, a disposição e a ternura, característica que a faz ser sempre lembrada com carinho pelos seus alunos e orientandos.

Aos professores José Levi do Amaral Júnior e Alexandre de Moraes, membros da banca de qualificação, agradeço os comentários, as críticas e sugestões que fizeram ao meu trabalho, permitindo a construção desta dissertação.

Aos amigos feitos na faculdade e que ainda hoje se fazem presente em minha vida e àqueles feitos antes mesmo de qualquer envolvimento meu com o Direito, gostaria de agradecer pela companhia e pela amizade que tornaram esses anos de pesquisa mais leves e agradáveis. Agradeço especialmente à Juliana Antunes, André Pardini, Belisa Eleotério, Hugo dos Passos, Jennifer Stadler, Ingrid Magalhães, Carlos Dantas, Aline Nakagawa, Paula Yasuda, Jéssica Faria, Marina Yamaoka, Luciana Nakaya, Renata Sakamoto, Danielle Miyamoto, Mariana Dias, Priscila Kawazoi, Denise Mizuno, Ana Carolina Miyawaki e Natália Jung.

Ao Icaro, agradeço pelo carinho, apoio, alegria e amor de todos os dias, e pelas doses extras de paciência e compreensão que lhe foram exigidas durante a realização deste trabalho.

À minha família, agradeço o carinho e dedicação de minha avó, Elza, e minha tia, Maria Nilza; a amizade, o amor e o apoio dos meus irmãos, Victor e Rafael (e a este também por toda ajuda com esta dissertação, mesmo com a distância). Aos meus pais, Cristina e José Leonidas, sendo impossível me expressar melhor, gostaria de dizer que sempre serei grata por tudo. 


\section{Resumo}

Os já conhecidos questionamentos acerca da legitimidade democrática do controle judicial de constitucionalidade vieram à pauta no Brasil, sobretudo a partir da Constituição Federal de 1988. Questiona-se a legitimidade do Supremo Tribunal Federal, cujos membros não são eleitos, de poder declarar inconstitucionais e excluir do ordenamento jurídico atos normativos editados por órgãos cujos membros são eleitos pelo povo. No mesmo período, em razão do processo de abertura democrática vivido no país, o texto constitucional e a legislação ordinária criaram instrumentos para ampliar a participação popular, inclusive no âmbito da jurisdição constitucional, e a intervenção do amicus curiae, a realização de audiências públicas e a ampliação do acesso à jurisdição constitucional concentrada passaram a ser festejados pela doutrina como meios de democratizar e conferir maior legitimação às decisões proferidas no controle concentrado de constitucionalidade. Esta dissertação analisa separadamente cada um desses três mecanismos a fim de constatar de que maneira e em que medida eles podem corresponder a essa expectativa e diminuir o déficit de legitimidade democrática do STF. Mostra-se que, da forma como são tratados pela legislação e utilizados, tais instrumentos não contribuem como poderiam para essa democratização, em razão principalmente da regulamentação escassa e da interpretação restritiva aplicada pelo Supremo Tribunal Federal. Diante dessa constatação, o trabalho aponta alguns caminhos para que as audiências públicas, o amicus curiae e a legitimação para proposição das ações de controle concentrado de constitucionalidade possam contribuir ainda mais com esse objetivo. 


\section{Résumé}

Les déjà connues questions sur la légitimité démocratique du contrôle judiciaire de constitutionnalité sont venues à l'ordre du jour au Brésil, en particulier après la Constitution de 1988. La légitimité de la Cour Suprême, dont les membres ne sont pas élus, est contestée par sa compétence de déclarer inconstitutionnels et par exclure les actes juridiques émis par des organismes dont les membres sont élus par le peuple. Dans la même période, en raison du processus d'ouverture démocratique observé dans le pays, la Constitution et les lois ordinaires ont créé des instruments pour élargir la participation populaire, notamment au sein de la juridiction constitutionnelle. Et l'intervention de l'amicus curiae, la tenue d'audiences publiques et l'extension de l'accès au contrôle de constitutionnalité concentré ont été célebrés par la doctrine comme un moyen de démocratiser et de conférer une plus grande légitimité aux décisions rendues dans le contrôle de constitutionnalité concentré. Cette dissertation analyse séparément chacun de ces trois mécanismes afin de déterminer de quelle manière et dans quelle mesure ils peuvent correspondre à cette expectative et réduire le déficit de légitimité démocratique de la Cour Suprême. Il est montré que, compte tenue de la façon dont ils sont traités par la loi et utilisés par la Cour, ces instruments ne contribuent pas, tels qu'ils auraient pu, à cette démocratisation, surtout en raison d'une insuffisante réglementation et de l'interprétation restrictive appliquée par la Cour Suprême. Considérant ce fait, ce travail indique quelques chemins pour que les audiences publiques, l'amicus curiae et la légitimité à proposer des mesures de contrôle de constitutionnalité concentré puissent contribuer davantage à cet objectif. 


\section{Índice}

Introdução ........................................................................................................................ 1

Primeira Parte: Legitimação e abertura do controle concentrado de constitucionalidade ............................................................................................................. 4

1.1. O caráter contramajoritário do controle judicial de constitucionalidade ........... 4

1.2. A questão da legitimidade da jurisdição constitucional no Brasil ................... 10

1.3. Evolução da abertura da jurisdição constitucional concentrada à sociedade... 18

Segunda Parte: Mecanismos de legitimação da jurisdição constitucional concentrada

2. Audiência pública.................................................................................................... 27

2.1. Disciplina normativa no âmbito do Supremo Tribunal Federal ..................... 27

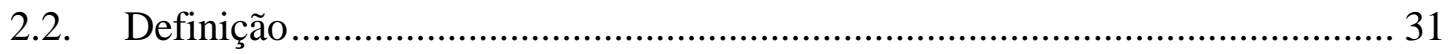

2.3. Histórico das audiências públicas realizadas .................................................. 33

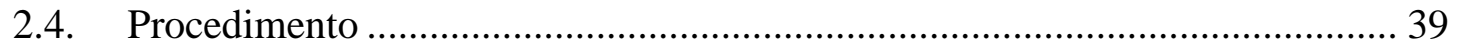

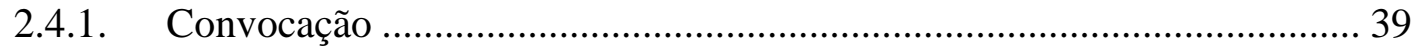

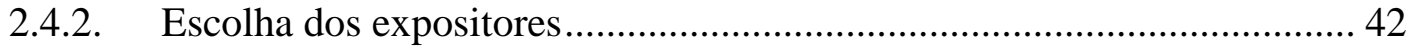

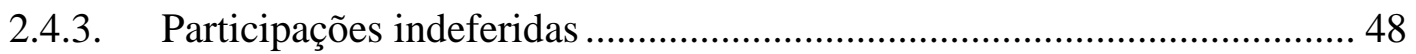

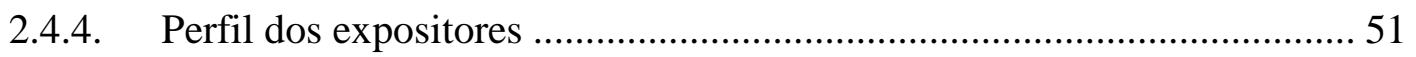

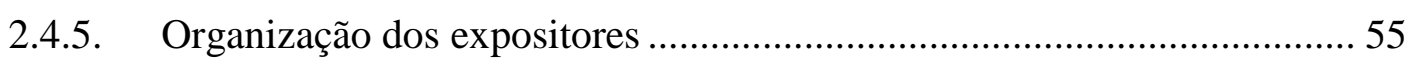

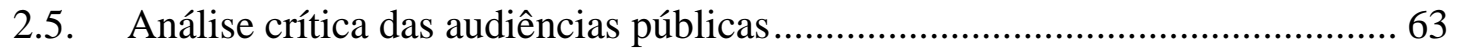

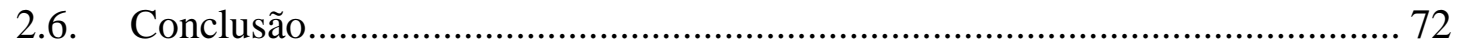

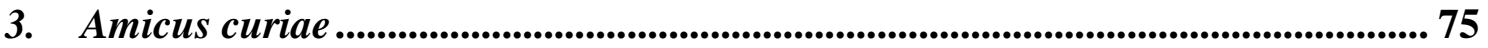

3.1. Histórico normativo na jurisdição constitucional concentrada....................... 75

3.2. Definição e características .......................................................................... 81

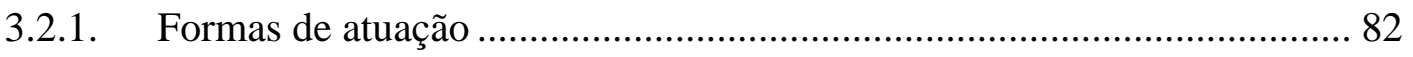

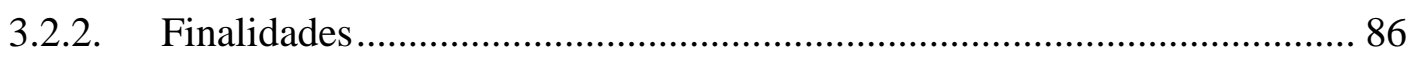

3.2.3. Diferenças entre amicus curiae e audiência pública .............................. 87

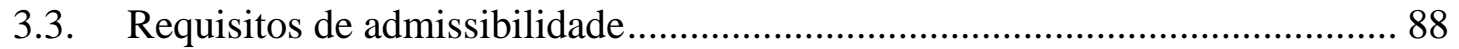

3.4. Análise crítica do amicus curiae ................................................................... 100

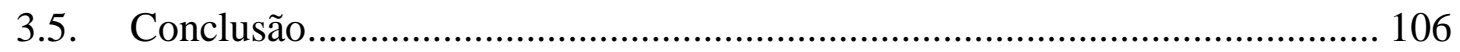

4. Legitimados para propor ação direta de controle de constitucionalidade..... 109

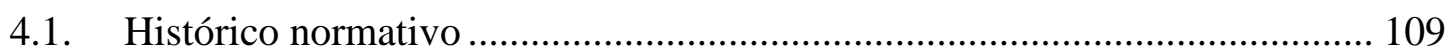




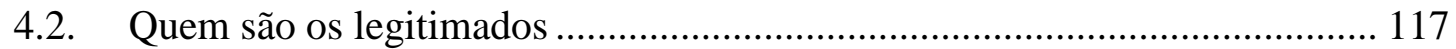

4.2.1. Pertinência temática............................................................................... 118

4.2.2. A interpretação e admissão dos legitimados.......................................... 123

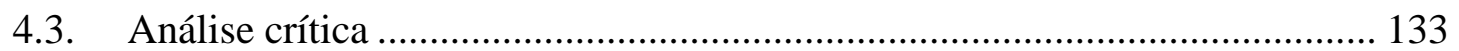

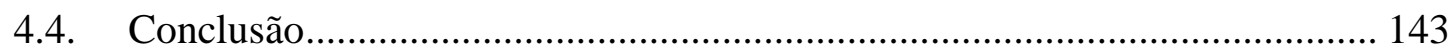

Conclusão geral.................................................................................................................... 146

Bibliografia ...................................................................................................................................... 149 


\section{Introdução}

Ao abrir os principais jornais e revistas do país, fica evidente a atenção dispensada ao Supremo Tribunal Federal na atualidade. Seja entre os juristas ou mesmo entre não especialistas, suas sessões - transmitidas pela TV Justiça e pela internet - e decisões nunca foram tão comentadas quanto nos dias de hoje.

O maior destaque adquirido pelo órgão nos últimos anos, sobretudo a partir da Constituição Federal de 1988, que aumentou consideravelmente suas competências, trouxe à pauta os não tão recentes questionamentos acerca da legitimidade democrática desse tipo de instituição.

Questiona-se se um órgão como o Supremo Tribunal Federal, composto por onze membros que não foram eleitos pela sociedade, teria legitimidade suficiente para declarar inconstitucional e, consequentemente, anular aquilo que foi produzido por órgãos democraticamente eleitos e, por isso, mais legitimados a tomar decisões.

Nesse mesmo período, o próprio texto constitucional, bem como a legislação ordinária, em razão do processo de abertura democrática vivido no país, criaram instrumentos para ampliar a participação popular, inclusive no âmbito da jurisdição constitucional concentrada.

Nesse contexto, tais inovações trazidas pelo novo ordenamento jurídico, como a intervenção do amicus curiae, a realização de audiências públicas e a ampliação do acesso à jurisdição constitucional passaram a ser festejadas pela doutrina como meios de democratizar e conferir maior legitimação às decisões proferidas no controle concentrado de constitucionalidade.

Tal situação, bem como o crescente uso de tais institutos, demonstram a importância de um estudo aprofundado sobre os lineamentos, a aplicação, a função e a real contribuição desses elementos para a democratização da jurisdição constitucional concentrada no Brasil.

Tendo como pressuposto o caráter contramajoritário do controle jurisdicional de constitucionalidade e as críticas a seu possível déficit de legitimidade democrática, este 
trabalho propõe um estudo dos institutos do amicus curiae e da audiência pública, bem como do rol de legitimados a propor ações diretas de controle, para aferir se tais recursos, do modo como estão regulamentados e são aplicados, podem de fato contribuir com o aumento de legitimidade das decisões do STF.

Esta dissertação é dividida em duas partes. A primeira tem por objetivo trazer um breve panorama da discussão existente sobre a legitimidade democrática de órgãos judiciais no controle concentrado de constitucionalidade. A ideia é demonstrar, de maneira sucinta, que o debate, embora de origem remota, ainda hoje se faz presente no mundo todo.

No mesmo capítulo, tal questão é abordada tendo em vista as particularidades do ordenamento jurídico brasileiro e as características do Supremo Tribunal Federal, provando-se, assim, que, embora aqui o debate seja menos intenso e mais recente, é compatível e importante para a compreensão e o desenvolvimento do Direito Constitucional nacional.

Dedica-se ainda parte desse capítulo a uma rápida apresentação do processo de abertura à participação popular ocorrido no Brasil após a Constituição Federal de 1988 e suas posteriores modificações. É nesse contexto que surgem mecanismos apontados pela doutrina como passíveis de acrescer legitimidade democrática à jurisdição constitucional concentrada, e que serão objeto da etapa seguinte deste trabalho.

A segunda parte dessa dissertação traz um estudo aprofundado das três principais inovações trazidas pelo ordenamento jurídico no que diz respeito à abertura da jurisdição constitucional concentrada à sociedade: a audiência pública, o amicus curiae e a ampliação do rol de legitimados a propor ação de controle concentrado de constitucionalidade.

Esses instrumentos, como dito, são festejados por boa parte da doutrina e pelos próprios membros do STF como meios capazes de contribuir com o aumento da legitimidade democrática do Tribunal e têm sido cada vez mais utilizados na jurisdição constitucional. $\mathrm{O}$ escopo segunda da etapa é justamente analisar em que medida essas três inovações podem contribuir com a democratização da jurisdição constitucional. 
O estudo de cada um desses institutos é feito separadamente, em capítulos distintos, e engloba três aspectos: além de apresentar o tratamento normativo dado a cada um - que, como se verá, não é muito extenso - e de reportar e analisar as considerações trazidas pela doutrina, este trabalho também estuda de que forma essas inovações são utilizadas, na prática, pelo STF. Como será demonstrado, é o tratamento dispensado pelo Tribunal a cada um desses mecanismos que, de fato, os caracterizará.

Após a análise de todas essas informações, a conclusão avalia em que medida esses três instrumentos são capazes de contribuir para a abertura do Supremo Tribunal Federal à participação da sociedade, sugerindo ainda formas de torná-los mais eficazes nesta função, tão exaltada pela doutrina e pelo próprio STF. 


\section{Primeira Parte: Legitimação e abertura do controle concentrado de constitucionalidade}

\subsection{0 caráter contramajoritário do controle judicial de constitucionalidade}

O papel desempenhado por diversos Tribunais Constitucionais, de último intérprete da Constituição - já que podem rever os atos normativos dos demais órgãos e suas decisões jurídicas não estão sujeitas a qualquer controle posterior - foi objeto de debate entre muitos autores, em especial Carl Schmitt ${ }^{1}$ e Hans Kelsen ${ }^{2}$, e ainda hoje é alvo de muita discussão entre os constitucionalistas.

Embora tenha adquirido contornos distintos ${ }^{3}$ dos adotados no embate entre o jurista alemão e o austríaco sobre quem deveria ser o guardião da Constituição, o debate sobre a competência para a realização do controle de constitucionalidade ainda suscita significativas divergências na doutrina constitucional.

Alguns autores questionam o fato de um órgão como o Supremo Tribunal Federal, por exemplo, que é composto por onze membros que não foram eleitos pela sociedade, declarar a inconstitucionalidade e, consequentemente, anular os atos normativos produzidos por órgãos direta e democraticamente legitimados, como o Parlamento e até mesmo o Poder Executivo.

É esse questionamento que Jeremy Waldron levanta, de maneira relativamente irônica, ao escrever:

"Quando alguém pergunta 'Quem deve decidir quais os direitos que temos?', uma resposta (a minha resposta) é: ‘As pessoas cujos direitos estão sendo discutidos têm o direito de participar em igualdade de condições dessa decisão'. Mas essa não é a única resposta possível. Em vez de dar poder ao povo alegando que são, afinal, os seus direitos que estão em jogo,

\footnotetext{
${ }^{1}$ Carl Schmitt, O guardião da constituição, Belo Horizonte: Del Rey, 2007.

${ }^{2}$ Hans Kelsen, "Quem deve ser o guardião da Constituição?" in Hans Kelsen, Jurisdição Constitucional, São Paulo: Martins Fontes, 2003.

${ }^{3}$ Nesse sentido, ver Virgílio Afonso da Silva, "O STF e o Controle de Constitucionalidade: Deliberação, Diálogo e Razão Pública”, Revista de Direito Administrativo, v. 250, 2009, pp.205-206.
} 
poderíamos confiar a decisão final a uma elite acadêmica ou judicial, alegando que eles têm maior probabilidade de decidir acertadamente."4

Tal passagem ressalta o poder contramajoritário da jurisdição constitucional, entendido aqui como sua função de analisar e, considerando-os inconstitucionais, anular atos votados e aprovados majoritariamente, por representantes eleitos pelos cidadãos ${ }^{5}$.

É esse caráter contramajoritário do controle jurisdicional de constitucionalidade o alvo de parte das críticas da doutrina. Por poder contrariar o entendimento firmado por uma maioria escolhida pela sociedade para representá-la, há quem questione a legitimidade democrática desse Tribunal. Por que caberia ao Tribunal dar a última palavra sobre a constitucionalidade das leis, e não aos legisladores eleitos pelo povo?

O principal argumento da crítica contramajoritária é assim sintetizado por Marcos Paulo Veríssimo: "confiar aos juízes a definição das questões políticas centrais a uma sociedade significa, em última análise, desconfiar da capacidade da própria sociedade de determinar-se"

Os argumentos frequentemente sustentados por aqueles que defendem que a decisão final deve ser atribuída ao controle judicial de constitucionalidade são rebatidos por doutrinadores com posicionamento diverso. Há um intenso debate na doutrina, como será demonstrado, sinteticamente, neste tópico.

Um dos principais argumentos a favor da jurisdição constitucional é de que ela é essencial à democracia, por garantir as condições necessárias ao exercício do próprio jogo democrático ${ }^{7}$. Essa proteção se daria porque na Corte, diferentemente do que

\footnotetext{
4 "When someone asks, 'Who shall decide what rights we have?', one answer ( $m y$ answer) is: 'The people whose rights are in question have the right to participate on equal terms in that decision'. But it is not the only possible answer. Instead of empowering the people on the grounds that it is after all their rights that are at stake, we might instead entrust final authority to a scholarly or judicial elite, on the ground that they are more likely to get the matter right." (Jeremy Waldron, Law and Disagreement, New York: Oxford University Press, 1999, p.244.)

5 Gustavo Binenbojm, A Nova Jurisdição Constitucional Brasileira - Legitimidade democrática e Instrumentos de realização, Rio de Janeiro: Renovar, 2010, p.278.

${ }^{6}$ Marcos Paulo Veríssimo, A judicialização dos conflitos de justiça distributiva no Brasil: O processo judicial no pós-1988, São Paulo: tese de doutorado (Faculdade de Direito da Universidade de São Paulo), 2006, pp.78-79.

${ }^{7}$ Nesse sentido ver Gustavo Binenbojm, Op. cit., p.278.
} 
ocorreria no Parlamento, haveria uma verdadeira deliberação ${ }^{8}$ pautada por argumentos de princípio que resultaria em uma decisão moral $^{9}$, e não um resultado obtido meramente pela soma do voto da maioria ${ }^{10}$.

Refutando essa ideia, Conrado Hübner Mendes explica que há nessa perspectiva uma distorção que "desqualifica como 'meramente procedimental' o conceito de democracia que defende a prevalecência do legislador na resolução de dilemas morais coletivos" ${ }^{\prime 1}$.

Assim como no âmbito do Tribunal, há debate e deliberação entre os parlamentares. Se a Corte tem o dever de motivar suas decisões, Jeremy Waldron lembra que o Legislativo também fundamenta com grande qualidade argumentativa seus posicionamentos nos debates parlamentares, que são registrados ${ }^{12}$. Além disso, alega que a linguagem utilizada pela Corte, própria de juristas, e a preocupação em legitimarem suas decisões comprometeriam a correta compreensão de seus argumentos pela sociedade ${ }^{13}$, ao passo que, no parlamento, a linguagem e as discussões aproximariam a população.

Ainda contra esse argumento favorável ao controle jurisdicional de constitucionalidade, há quem entenda que não só o processo de deliberação que ocorre no Legislativo e na Corte é similar, mas que o próprio procedimento utilizado para se chegar à decisão final é o mesmo: se entre os parlamentares somam-se votos para encontrar a posição da

\footnotetext{
8 Robert Alexy, "Balancing, constitutional review, and Representation", International Journal of Constitutional Law, Vol. 3, N. 4, pp. 572-581, 2005, pp.578-581.

${ }^{9}$ Ver Conrado Hübner Mendes, Controle de Constitucionalidade e Democracia, São Paulo e Rio de Janeiro: Campus Elsevier, 2007, p.44.

${ }^{10}$ Ronald Dworkin, Is democracy possible here? - Principles for a new political debate, New Jersey: Princeton University, 2006, pp.131-132, 134.

${ }^{11}$ Conrado Hübner Mendes, Direitos fundamentais, separação de poderes e deliberação, São Paulo: Tese de doutorado (Faculdade de Filosofia, Letras e Ciências Humanas da Universidade de São Paulo), 2008, p.86.

12 "Courts give reasons for their decisions, we are told, and this is a token of taking seriously what is at stake, whereas legislatures do not. In fact, this is a false contrast. Legislators give reasons for their votes just as judges do. The reasons are given in what we call debate and they are published in Hansard or the Congressional Record. The difference is that lawyers are trained to close study of the reasons that judges give; they are not trained to close study of legislative reasoning (though they will occasionally ransack it for interpretive purposes)." (Jeremy Waldron, "The core of the case against judicial review", The Yale Law Journal, New Haven, v.115, 2006, p.1382)

13 "Distracted by these issues of legitimacy, courts focus on what other courts have done, or what the language of the Bill of Rights is, whereas legislators-for all their vices-tend at least to go directly to the heart of the matter." (Jeremy Waldron, Op. cit., p.1384.)
} 
maioria, na Corte a decisão, na prática ${ }^{14}$, não passa da soma de votos individuais de seus membros ${ }^{15}$.

Sobre esse procedimento, Virgílio Afonso da Silva analisa:

“É claro que, neste ponto, alguém poderia sustentar que não há nada de errado com esse sistema, já que ele é o sistema decisório por excelência em órgãos colegiados. Ou seja: o Supremo Tribunal Federal decide da mesma forma que decidem a Câmara dos Deputados e o Senado Federal, por meio de uma espécie de placar final. Ora, mas se o que legitima a possibilidade de controle judicial de constitucionalidade é justamente a deliberação e a busca por uma razão pública, não faz sentido que a forma de decisão do STF seja igual àquela dos poderes políticos" ${ }^{" 16}$ (Grifamos)

Seguindo esse raciocínio, a única diferença, portanto, entre uma decisão obtida no Legislativo ou na Corte seria justamente quem vota: no primeiro caso, representates escolhidos pelo povo; no segundo, juízes não eleitos.

Outro argumento recorrente em favor da legitimidade do controle jurisdicional de constitucionalidade é o de que a Corte, ao invalidar algumas decisões tomadas pela maioria legislativa com base na interpretação das normas constitucionais, estaria defendendo as escolhas do constituinte ${ }^{17} \mathrm{e}$, desse modo, protegendo todo o povo da chamada "tirania da maioria" 18 .

Segundo Robert Alexy, "a representação do povo pelo tribunal constitucional tem um caráter mais idealístico do que aquela pelo parlamento. A vida cotidiana do funcionamento parlamentar oculta o perigo que maiorias se imponham desconsideradamente, emoções determinem o acontecimento, dinheiro e relações de

\footnotetext{
${ }^{14}$ Críticas à forma como o STF formula suas decisões podem ser lidas em Virgílio Afonso da Silva, "O STF e o controle de constitucionalidade: deliberação, diálogo e razão pública", p.217.

${ }_{16}^{15}$ Nesse sentido, ver também Jeremy Waldron, Op. cit., pp.1391-1392.

${ }^{16}$ Virgílio Afonso da Silva, "O STF e o controle de constitucionalidade: deliberação, diálogo e razão pública", p.217, nt. 77.

${ }^{17}$ Alexandre de Moraes, Jurisdição Constitucional e Tribunais Constitucionais: Garantia Suprema da Constituição, 2. Ed., São Paulo: Atlas, 2003, pp.68-69.

${ }^{18}$ Nesse sentido ver Luís Roberto Barroso, O Controle de Constitucionalidade no Direito Brasileiro, 4. Ed., São Paulo: Saraiva, 2009, p.55; Ronald Dworkin, Is Democracy Possible Here? - Principles for a new political debate, pp.144-145.
} 
poder dominem e simplesmente sejam cometidas faltas graves. Um tribunal constitucional que se dirige contra tal não se dirige contra o povo senão, em nome do povo, contra seus representantes políticos." ${ }^{, 19}$

Todavia, tal explicação pode mostrar-se problemática, uma vez que, em muitos casos, a norma constitucional pode dar ensejo a múltiplas interpretações, cabendo ao juiz constitucional definir qual dessas interpretações será aplicada. Nessas situações, é difícil argumentar que a atuação da Corte Constitucional consiste na mera defesa de uma escolha feita pelo povo durante o processo constituinte, e não em uma opção da própria Corte.

Já sobre a expressão "tirania da maioria", Conrado Hübner Mendes explica que "não há nada de necessariamente tirânico no fato de que uma minoria perca no parlamento, mesmo que com frequência" e que "tirania da maioria não deve ser confundida, por isso, com qualquer situação de desacordo"20. Para Jeremy Waldron, a situação só se apresenta preocupante quando a minoria que perde no parlamento coincide com a minoria que é afetada pela decisão ${ }^{21}$.

Assim entende Jeremy Waldron ${ }^{22}$ :

“Pelo fato da expressão 'tirania da maioria' ser tão comumente falada, nós tendemos a esquecer outras formas de tirania, nós tendemos a esquecer que a legitimidade é uma questão que diz respeito a toda e qualquer autoridade política.(...)

Outros sistemas políticos têm os mesmos perigos relacionados com a legitimidade do majoritarismo popular: eles podem tomar decisões erradas; eles podem influenciar injustamente indivíduos ou grupos específicos; em suma, eles podem agir tiranicamente. Mas eles têm, além disso, um problema de legitimidade que o majoritarismo popular não tem: eles não permitem uma voz e um voto, em um processo de decisão final, para todos

\footnotetext{
19 Robert Alexy, "Direitos Fundamentais no Estado Constitucional Democrático: para a relação entre direitos do homem, direitos fundamentais, democracia e jurisdição constitucional", Trad. port. Luís Afonso Heck, Revista de Direito Administrativo, v. 217, jul/set. 1999, p.66.

${ }^{20}$ Conrado Hübner Mendes, Direitos fundamentais, separação de poderes e deliberação, p.87.

${ }^{21}$ Jeremy Waldron, "The core of the case against judicial review", p.1397.

22 No mesmo sentido, ver Carlos Santiago Nino, La constitución de la democracia deliberativa, Barcelona: Gedisa, 1997, p.260.
} 
os cidadãos da sociedade; em vez disso, eles passam a tomar as decisões finais sobre os direitos de milhões de pessoas baseados nas vozes e votos de alguns.",23

Por fim, parte da doutrina defende, de forma recorrente, que a Corte encontra-se em melhor posição para dar a última palavra acerca da constitucionalidade de atos normativos, seja por creditar a ela uma imparcialidade inexistente em um órgão cujos membros são eleitos ${ }^{24}$, seja por entender que ela é mais apta ou possui mais informações para decidir.

Com relação à neutralidade de seus membros - que não existiria, por exemplo, entre os legisladores, por estarem inseridos na política - tal argumento é rebatido ${ }^{25}$ por quem entende que, por não se tratar da análise de um caso concreto, mas do controle abstrato de constitucionalidade, sua decisão afeta toda a sociedade, de modo que "nesse terreno, não há uma autoridade que esteja na condição de terceiro não interessado, que não possa julgar em causa própria" 26 .

Contra o argumento de que a Corte seria mais informada e, por isso, estaria mais apta a decidir, Conrado Hübner Mendes pondera, ressaltando que ela "frequentemente estará menos informada que o parlamento", já que "este dispõe de inúmeros recursos para captar informações de variados grupos sociais, e tem melhor noção de impacto da lei pela experiência legislativa anterior (afinal, raros são os temas que, hoje, começam do zero sua história legislativa)" ${ }^{\prime 27}$.

\footnotetext{
23 'Because the phrase 'tyranny of the majority' trips so easily off the tongue, we tend to forget about others forms of tyranny; we tend to forget that legitimacy is an issue that pertains to all political authority. (...) Other political systems have all the legitimacy-related dangers of popular majoritarianism: they may get things wrong; they may have an injust impact on particular individuals or groups; in short, they may act tyrannically. But they have in addition one legitimacy-related defect that popular majoritarianism does not have: they do not allow a voice and a vote in a final decision-procedure to every citizen of the society; instead they proceed to make final decisions about the rights of millions on the basis of the voices and votes of a few." (Law and Disagreement, p.299.)

24 "First, constitutional judges are, in at least two senses, impartial. In most modern constitutional regimes, high court judges are not elected and hence are not vicariously attached to the immediate interests-personal or political—of members of their political community." (Lawrence G. Sager, "Constitutional Justice", New York University Journal of Legislation and Public Policy, n.6, 2002, p.14.)

${ }^{25}$ Ver Jeremy Waldron, Law and Disagreement, p.297.

${ }^{26}$ Conrado Hübner Mendes, Direitos fundamentais, separação de poderes e deliberação, p.90.

${ }^{27}$ Conrado Hübner Mendes, Op. cit., p.91.
} 
Discordando ainda da ideia de que a Corte seria mais apta a decidir do que o Legislativo, Carlos Santiago Nino argumenta:

“A visão habitual de que os juízes estão em melhor posição do que os parlamentos e outros órgãos cujos membros são eleitos pelo povo para resolver questões relacionadas com direitos parece ser o resultado de algum tipo de elitismo epistemológico. Este pressupõe que para chegar a conclusões morais corretas, a habilidade intelectual é mais importante do que a capacidade de representar e equilibrar os interesses de todos os afetados pela decisão."28

Essas são apenas algumas das questões envolvendo a legitimidade da jurisdição constitucional. A polarização entre argumentos que justificam o controle judicial de constitucionalidade e que refutam essa possibilidade não significa, no entanto, que haja apenas dois cenários possíveis - um que defende o controle judicial irrestrito e outro que reputa toda atuação judicial como ilegítima e antidemocrática ${ }^{29}$.

Não é o escopo deste trabalho, porém, esgotar o tema e nem mesmo adotar um posicionamento a respeito dos distintos entendimentos existentes. Com esta breve exposição de argumentos contrapostos pretende-se apenas demonstrar que o debate acerca da legitimidade democrática do controle de constitucionalidade judicial não está superado. Pelo contrário, a discussão permanece em aberto, suscitando significativas divergências na doutrina constitucional pelo mundo.

\subsection{A questão da legitimidade da jurisdição constitucional no Brasil}

\footnotetext{
28 "La perspectiva usual de que los jueces están mejor situados que los parlamentos y que otros funcionarios elegidos por el pueblo para resolver cuestiones que tengan que ver con derechos, parece ser la consecuencia de cierto tipo de elitismo epistemológico. Este último pressupone que, para alcanzar conclusiones morales correctas, la destreza intelectual es más importante que la capacidad para representarse y equilibrar imparcialmente los intereses de todos los afectados por la decisión." (Carlos Santiago Nino, La constitución de la democracia deliberativa, p.260)

29 Acerca de arranjos intermediários, ver Virgílio Afonso da Silva, "O STF e o Controle de Constitucionalidade: Deliberação, Diálogo e Razão Pública”, pp.220 -223; Jeremy Webber, "Democratic Decision Making as the First Principle of Contemporary Constitutionalism" in Richard Bauman e Tsvi Kahana [org.], The Least Examined Branch: The Role of Legislation in the Constitutional State, Cambridge: Cambridge University Press, 2006.
} 
Antes de prosseguir essa exposição, cumpre esclarecer que, embora esse debate seja mais intenso no direito constitucional estadunidense, país que, ao contrário do Brasil, não consagra a defesa da Constituição pela Suprema Corte em seu texto constitucional, ele não se restringe a países em que o constituinte silenciou sobre a guarda da Constituição.

A respeito da literatura norte-americana, Conrado Hübner Mendes entende que "é quase inevitável passar por ela: eles inventaram a instituição, formularam a pergunta e elaboraram as principais respostas"30. Mas ressalta a importância de se verificar se de fato o debate lá existente pode ser transportado para a nossa realidade:

"O mínimo denominador comum de todos os sistemas de controle de constitucionalidade, nos quais faz algum sentido debater a legitmidade democrática, é um 'fato cru': um arranjo institucional que permite ao poder judiciário, em algum momento e com alguma intensidade, revogar, a título de incompatibilidade com a constituição, uma lei editada pelo parlamento representativo." 31

Essa situação indubitavelmente se faz presente na realidade brasileira, já que a Constituição Federal assim prevê:

"Art. 102. Compete ao Supremo Tribunal Federal, precipuamente, a guarda da Constituição, cabendo-lhe:

I - processar e julgar, originariamente:

a) a ação direta de inconstitucionalidade de lei ou ato normativo federal ou estadual e a ação declaratória de constitucionalidade de lei ou ato normativo federal;

$(\ldots)$

$\S 10^{\circ}$ A arguição de descumprimento de preceito fundamental, decorrente desta Constituição, será apreciada pelo Supremo Tribunal Federal, na forma da lei."

\footnotetext{
${ }^{30}$ Conrado Hübner Mendes, Direitos fundamentais, separação de poderes e deliberação, p. 23 .

${ }^{31}$ Conrado Hübner Mendes, Op. cit., p.24.
} 
Embora haja quem entenda que no Brasil tal discussão seja menos relevante ${ }^{32}$, algumas particularidades da nossa forma de organização do Estado evidenciam a importância do debate também pela doutrina nacional.

Se nos Estados Unidos da América, por exemplo, geram-se grandes discussões por poder a Suprema Corte opor-se ao entendimento do legislador, aqui a questão parece ainda mais complexa:

"No sistema brasileiro, a última palavra não é apenas contra o legislador ordinário. Em virtude das cláusulas pétreas, é também contra o poder constituinte derivado, o poder reformador da Constituição. Contra o ato legislativo dignitário do maior consenso deliberativo - a emenda constitucional.",33

Assim, se a Corte julgar inconstitucional lei editada pelo Poder Legislativo, este ainda poderá, fazendo as vezes de poder constituinte derivado, aprovar, por meio de processo mais complexo, uma emenda constitucional. No Brasil, porém, essa emenda poderá ser submetida a mais uma avaliação pelo $\mathrm{STF}^{34}$ - para evitar que o legislador contrarie as cláusulas pétreas. Se o STF rejeitar a emenda, findam-se os caminhos para a manifestação legislativa, não havendo outras vias institucionais para que a medida seja $\operatorname{aprovada}^{35}$.

É em razão dessa particularidade que Conrado Hübner Mendes, ao avaliar a relação dos questionamentos feitos pela doutrina internacional - sobretudo norte-americana - com a realidade brasileira, afirma que "se há dessemelhanças entre os dois sistemas

\footnotetext{
${ }^{32}$ Ver Marcos Paulo Veríssimo, Op. cit., p.80.

${ }^{33}$ Conrado Hübner Mendes, Controle de Constitucionalidade e Democracia, p.22.

${ }^{34}$ Não há, em verdade, previsão expressa de tal competência do STF na Constituição Federal de 1988. O STF, entretanto, extraiu esse entendimento do art.102, I do texto constitucional, a partir do julgamento das ADIs 926 e 939, que julgaram a emenda constitucional criadora do IPMF. Conrado Hübner Mendes ressalta que há outras constituições que prevêem cláusulas pétreas, mas que, no mundo todo, apenas o Supremo Tribunal Federal e o Tribunal Constitucional Indiano declararam a inconstitucionalidade de uma emenda constitucional. (Op. cit., p.146)

${ }^{35}$ Até o momento de conclusão desta dissertação, a PEC 33, que submete a decisão do STF que declara inconstitucional uma emenda constitucional à aprovação do Congresso Nacional, encontra-se em processo de discussão.
} 
[americano e brasileiro], elas pesam mais contra o brasileiro, tornam as críticas de lá ainda mais avassaladoras aqui,"36.

Vê-se, portanto, não só a adequação do debate realizado por doutrinadores estrangeiros ao contexto brasileiro como também a necessidade da análise da questão pela doutrina nacional. Se não é de hoje que o caráter contramajoritário do controle judicial de constitucionalidade é discutido ao redor do mundo, no Brasil, porém, tal questão passou a ser mais debatida e estudada apenas nas últimas décadas.

Conrado Hübner Mendes explica essa demora:

“O fato de a discussão não ter alcançado maior envergadura no decorrer de todo o século no Brasil não causa surpresa. Importou-se o modelo num momento de transição para a república, e essa instituição proporcionava ao regime que se instalava um importante valor de face, um atestado de que se compatibilizava com a exemplar e bem-sucedida engenharia institucional norte-americana. Mas o poder-força, no Brasil, não deixou a Corte e o próprio direito constitucional exercerem o papel que lhes cabia: domesticar o poder político e inseri-lo sob a regulação jurídica. Somente agora isso volta a conquistar algum respeito institucional., ${ }^{, 37}$

Ainda sobre o fato de os debates não serem tão intensos no país, o autor completa:

“A ciência política brasileira também não reservou grande atenção ao tema. Talvez porque o STF raramente tenha incomodado o Legislativo e o Executivo - a não ser em breves momentos, antes de ser sufocado por atos de violência. Não houve, realmente, maiores motivos para se preocupar com ele., 38

\footnotetext{
${ }^{36}$ Conrado Hübner Mendes, Controle de Constitucionalidade e Democracia, p.27.

${ }^{37}$ Ibidem, p. 191 .

${ }^{38}$ Ibidem, p.192.
} 
Além desses fatores, o debate tardio e menos intenso no Brasil deve-se, inegavelmente, às mudanças realizadas pela Constituição Federal de 1988 e suas posteriores alterações $^{39}$, como explica Oscar Vilhena Vieira:

“As mudanças na esfera da jurisdição constitucional impostas pela Constituição de 1988 tiveram um forte impacto sobre o papel do Supremo Tribunal Federal no sistema político brasileiro. A ampliação do acesso, o estabelecimento de novas competências, somada a própria extensão do direito constitucional sobre campos antes reservados ao direito ordinário, transformaram o Supremo Tribunal Federal numa importante e cada vez mais demandada arena de solução de conflitos políticos, colocando-o numa posição central em nosso sistema constitucional." ${ }^{\prime 40}$

Logo, o aumento das competências do Supremo Tribunal Federal, a criação de novas ações e a ampliação do rol de legitimados para propô-las, expandiram a atuação da Corte $^{41}$, fazendo com que ela passasse a assumir posição de destaque na sociedade, atraindo também maior atenção por parte da doutrina ${ }^{42}$, inclusive para seu caráter antimajoritário.

Sobre a questão, uma análise da doutrina nacional existente mostra que aqui também não há consenso entre os autores, embora haja quem entenda, como o Ministro do STF Luís Roberto Barroso, que "a tese da legitimidade do controle de constitucionalidade [judicial] foi amplamente vitoriosa, assim no debate acadêmico como na prática jurisprudencial, sem embargo da sucessão de períodos de maior ou menor ativismo judicial" 43 .

O autor defende a seguinte opinião:

\footnotetext{
39 Sobre a expansão do papel do Judiciário a partir de 1988, ver Marcos Paulo Veríssimo, Op. cit., pp. 150-155.

40 Oscar Vilhena Vieira, Supremo Tribunal Federal: Jurisprudência Política, 2. Ed., São Paulo: Malheiros, 2002, p. 217.

${ }^{41}$ Analisando-se apenas a questão numérica, vale registrar que o volume anual de processos recebidos pelo STF mais que quadriplicou entre a promulgação da atual Constituição Federal e o ano de 2004 (Marcos Paulo Veríssimo, Op. cit., p.152).

${ }^{42}$ Sobre o destaque alcançado ao STF, nos últimos anos, pelos estudiosos do Direito e pela sociedade em geral, ver Oscar Vilhena Vieira, "Supremocracia”, Revista Direito GV, São Paulo, pp.441-464, 2008.

${ }^{43}$ Luís Roberto Barroso, Op. cit., p.55.
} 
"De fato, o Poder Judiciário, integrado por agentes públicos não eleitos, pode invalidar atos do Executivo e do Legislativo, cujos membros têm o batismo do voto popular. Nada obstante, é certo que a democracia não se assenta apenas no princípio majoritário, mas também na realização de valores substantivos, na concretização dos direitos fundamentais e na observância de procedimentos que assegurem a participação livre e igualitária das pessoas. A tutela desses valores, direitos e procedimentos é o fundamento de legitimidade da jurisdição constitucional.",44 (Grifamos)

Já o também Ministro do STF Celso de Mello, em artigo sobre a relação do tribunal com a defesa das liberdades públicas, também entende que a jurisdição constitucional possui legitimidade, mas por outra razão:

"É preciso, pois, reafirmar a soberania da Constituição, proclamando-lhe a superioridade sobre todos os atos do Poder Público e sobre todas as instituições do Estado, o que permite reconhecer, no contexto do Estado Democrático de Direito, a plena legitimidade da atuação do Poder Judiciário na restauração da ordem jurídica lesada e, em particular, a intervenção do Supremo Tribunal Federal, que detém, em tema de interpretação constitucional, e por força de expressa delegação que lhe foi atribuída pela própria Assembleia Nacional Constituinte, o monopólio da última palavra (...)"45 (Grifamos)

Na mesma linha, o então Ministro do STF Carlos Ayres Britto, em voto no MS 26.602$3^{46}$, manifestou o seguinte entendimento:

“A legitimidade do Judiciário - e, mais de perto, a do Supremo Tribunal deflui da Constituição. O guardião da Constituição é também legítimo, porque defende uma vontade normativa nacional, depositada no Texto Magno, que é permanente e transgeracional desde o nascedouro. São duas

\footnotetext{
${ }^{44}$ Luís Roberto Barroso, Op. cit., p.350.

45 José Celso de Mello Filho, "O Supremo Tribunal Federal e a defesa das liberdades públicas sob a Constituição de 1988: alguns tópicos relevantes”, in Alexandre de Moraes [coord.], Os 20 Anos da Constituição da República Federativa do Brasil. Atlas: São Paulo, 2009, pp.537-538.

${ }^{46}$ Ver sessão Acompanhamento Processual, no site do STF.
} 
democracias, duas legitimidades. A nossa não é eletiva. Não fomos eleitos, mas somos os supremos guardiões da Constituição. Dessa guarda maior retiramos a nossa legitimidade."

Para Alexandre de Moraes, existem "três sustentáculos básicos da legitimidade da Justiça constitucional" 47 , que seriam: sua função de proteger os direitos fundamentais, os princípios constitucionais e os direitos da minoria ${ }^{48}$; a composição dos Tribunais Constitucionais, que deve ser plural, representativa e visar membros com experiências profissionais diversas e complementares ${ }^{49}$; o fato de seus pronunciamentos e decisões serem públicos e fundamentados, o que permite a aceitação e fiscalização desses pela opinião pública e os demais poderes ${ }^{50}$.

Parte da doutrina, todavia, sustenta a ausência ou insuficiência de legitimidade democrática do Poder Judiciário ao exercer tal função. É esse o entendimento de Manoel Gonçalves Ferreira Filho, que, por tal razão, propõe a criação de uma Corte especializada e não integrada ao Judiciário para realizar o controle de constitucionalidade:

"Isto [criação de uma Corte especializada] forneceria o elemento de legitimidade democrática que certamente não possui o Judiciário, Poder cujos membros são escolhidos por um método 'aristocrático', e não democrático, de seleção, ou seja, não são eleitos pelo povo, mas selecionados por concurso ou por escolha por autoridade política." 51 (Grifamos)

Se essa é a solução vislumbrada pelo constitucionalista para resolver a questão do déficit de legitimidade, outros autores apontam a abertura do processo de controle de constitucionalidade à participação da sociedade civil como forma de solucionar o problema.

\footnotetext{
${ }^{47}$ Alexandre de Moraes, Op. cit., p.67.

${ }^{48}$ Ibidem, pp.67-76.

${ }^{49}$ Ibidem, pp.77-78.

${ }^{50}$ Ibidem, pp.78-81.

${ }^{51}$ Manoel Gonçalves Ferreira Filho, Aspectos do Direito Constitucional Contemporâneo, 2. ed., São Paulo: Saraiva, 2009, p.243.
} 
Assim, nas palavras de Elival da Silva Ramos, "Os instrumentos de participação nos processos de controle e a motivação e publicidade das decisões neles produzidas constituem antídotos poderosos ao isolamento esquizofrênico, sob o prisma democrático-funcional, das Cortes Constitucionais" ${ }^{\text {. }}$.

A ampliação da participação social nos procedimentos de controle de constitucionalidade judicial é defendida até mesmo por quem entende que não há que se falar em ausência ou insuficiência de legitimidade democrática por parte do Poder Judiciário.

É o caso de Gustavo Binembojm, que assim se manifesta sobre legitimidade da jurisdição constitucional:

“A jurisdição constitucional é, portanto, uma instância de poder contramajoritário, no sentido de que sua função é mesmo a de anular determinados atos votados e aprovados, majoritariamente, por representates eleitos. Nada obstante, entende-se, hodiernamente, que os princípios e direitos fundamentais, constitucionalmente assegurados, são, em verdade, condições estruturantes e essenciais ao bom funcionamento do próprio regime democrático; assim, quando a justiça constitucional anula leis ofensivas a tais princípios ou direitos, sua intervenção se dá $a$ favor, e não contra a democracia. Esta a fonte maior de legitimidade da jurisdição constitucional." $^{, 53}$ (Grifamos)

Apesar desse entendimento, o autor defende que "para que a Corte Constitucional não se torne uma instância autoritária de poder - compondo um governo de juízes - que dita, de forma monolítica, as interpretações oficiais a serem dadas aos diversos dispositivos da Constituição, é mister fomentar a ideia de cidadania constitucional, de forma a criar uma sociedade aberta de intérpretes da Constituição". Para ele, "a maior ou menor autoridade da Corte Constitucional depende, necessariamente, de sua

\footnotetext{
${ }^{52}$ Elival da Silva Ramos, Perspectivas de Evolução do Controle de Constitucionalidade no Brasil, São Paulo: tese para concurso de Professor Titular (Faculdade de Direito da Universidade de São Paulo), 2005, p.429.

53 Gustavo Binenbojm, A nova Jurisdição Constitucional brasileira: Legitimidade democrática e instrumentos de realização, p.278.
} 
capacidade de estabelecer este diálogo com a sociedade e de gerar consenso, intelectual e moral, em torno de suas decisões" ${ }^{\text {, }}$.

Este trabalho não visa a discutir se o Supremo Tribunal Federal carece ou não de legitimidade, mas sim, diante do debate existente na doutrina, analisar se a abertura da jurisdição constitucional à sociedade pode contribuir, de alguma forma, para o acréscimo de legitimidade democrática de suas decisões.

\subsection{Evolução da abertura da jurisdição constitucional concentrada à sociedade}

Há no mundo todo uma tendência de ampliar e aperfeiçoar o regime de governo por via da democratização do exercício de poder. Na política democrática contemporânea, a representação eleitoral não é a única forma de participação possível, mas apenas uma de suas modalidades.

Essa tendência de permitir uma maior participação social é facilmente verificada nas Constituições atuais. A Constituição Federal brasileira de 1988, por sua vez, também adota o princípio da cidadania participativa, seja individualmente, seja por intermédio de grupos e associações voltadas aos interesses difusos e coletivos ou da comunidade em geral.

$\mathrm{Na}$ atividade legislativa, o texto constitucional prevê a participação popular, por exemplo, por intermédio do plebiscito, do referendo e da iniciativa popular ${ }^{55}$, pela participação nas comissões do Congresso Nacional por meio de audiências públicas, petições, reclamações, representações, queixas ou depoimentos ${ }^{56}$, entre outros meios. Já com relação à Administração Pública, a participação é prevista, por exemplo, pelo direito de petição ${ }^{57}$, direito de propositura de ação popular para controle dos atos administrativos $^{58}$ e pela sujeição de certos atos ao referendo popular ${ }^{59}$.

\footnotetext{
54 Gustavo Binenbojm, A nova Jurisdição Constitucional brasileira: Legitimidade democrática $e$ instrumentos de realização, p.279.

${ }^{55}$ Arts. 14 e 61, $\S 2^{\circ}$ da Constituição Federal.

${ }^{56}$ Art. 58, §2 $2^{\circ}$ II, IV e V da Constituição Federal.

${ }^{57}$ Art. $5^{\circ}$, XXXIII e XXXIV da Constituição Federal.

${ }^{58}$ Art. $5^{\circ}$, LXXIII da Constituição Federal.

${ }^{59}$ Art. 29, XII, art. 31, $3^{\circ}$, entre outros, da Constituição Federal.
} 
Essa tendência de democratização também alcançou a jurisdição constitucional concentrada, tanto pelas disposições constitucionais quanto pela legislação infraconstitucional.

No texto constitucional, fica evidente a intenção de maior abertura à sociedade na legitimação de uma série de atores ${ }^{60}$, incluindo entidades representativas da comunidade, para acionarem o controle concentrado de constitucionalidade - cujos instrumentos de provocação também foram ampliados com a Constituição de 1988 e suas posteriores modificações.

Já na legislação infraconstitucional, merecem destaques as Leis 9.868, de 10 de novembro de 1999, que disciplinou o processo e julgamento da ação direta de inconstitucionalidade e da ação declaratória de constitucionalidade perante o STF, e 9.882, de 3 de dezembro de 1999, que organizou o processo e julgamento da arguição de descumprimento de preceito fundamental perante o Supremo Tribunal.

Para Anna Candida da Cunha Ferraz, essas leis foram as responsáveis por firmar a participação democrática na jurisdição constitucional ${ }^{61}$. Entre os mecanismos de participação popular nelas previstos estão a admissão da intervenção do amicus curiae no sistema concentrado ${ }^{62}$ e a possibilidade de convocação de audiência pública para ouvir depoimentos de pessoas com experiência e autoridade na matéria ${ }^{63}$.

Essa abertura do controle concentrado de constitucionalidade à sociedade civil, por permitir que a população participe e seja ouvida pelos membros do STF, é apontada como uma forma de democratizar essa instância.

Nas palavras de Roger Stiefelmann Leal, “o direito processual adotado vem, assim, admitindo cada vez mais a participação de atores sociais e políticos dos mais diversos matizes nas questões suscitadas em sede de controle de constitucionalidade.

\footnotetext{
${ }^{60}$ Art. 103 da Constituição Federal.

${ }^{61}$ Anna Candida da Cunha Ferraz, "A projeção da democracia participativa na Jurisdição Constitucional no Brasil: As audiências públicas e sua adoção no modelo concentrado de constitucionalidade" in Carlos Bastide Horbath, Fernando Dias Menezes de Almeida, José Levi Mello do Amaral Júnior e Roger Stiefelmann Leal [coord.], Direito Constitucional, Estado de Direito e Democracia: Homenagem ao Prof. Manoel Gonçalves Ferreira Filho. São Paulo: Quartier Latin, 2011, p.87.

${ }^{62}$ Art. $7^{\circ}, \S 2^{\circ}$ da Lei $9.868 / 99$ e art. $6^{\circ}, \S 2^{\circ}$ da Lei $9.882 / 99$.

${ }^{63}$ Art. $9^{\circ}, \S 1^{\circ}$ da Lei $9.868 / 99$ e art. $6^{\circ}, \S 1^{\circ}$ da Lei $9.882 / 99$.
} 
Aos poucos, constrói-se um ambiente de legitimação política de algum modo semelhante ao processo legislativo" ${ }^{\circ 4}$. (Grifamos)

Reconhecendo em instrumentos como esses uma fonte de legitimidade para o controle judicial de constitucionalidade, Carlos Santiago Nino afirmou:

“Também é possível considerar procedimentos para assegurar que os membros dos tribunais superiores que exercem a revisão judicial possam receber periodicamente o apoio do processo democrático. Esses mecanismos não devem criar uma dependência no poder judiciário, como aquela que exercem sobre o poder político, mas simplesmente fornecer ao primeiro uma base de apoio democrático mais sólida." ${ }^{65}$

Seriam esses novos mecanismos e inovações trazidos pelo ordenamento jurídico capazes de pluralizar e, assim, acrescer legitimidade democrática - ou mesmo suprir sua ausência, para aqueles que acreditam que o STF carece de legitimação - a um órgão contramajoritário como o Supremo Tribunal Federal? É a essa questão que o presente estudo procura responder.

\footnotetext{
${ }^{64}$ Roger Stiefelmann Leal, O efeito vinculante na jurisdição constitucional, São Paulo: Saraiva, 2006, p.101.

65 "Es también posible considerar procedimientos que aseguren que los miembros de las cortes superiores que ejercitan el control judicial de constitucionalidad puedan periódicamente recibir apoyo del proceso democrático. Tales mecanismos no deberían crear una dependencia del poder judicial de aquellos que ejercitan el poder político, sino que simplemente proveerían al primero de una base de apoyo democrático más sólida." (La constitución de la democracia deliberativa, p.292.)
} 


\section{Segunda Parte: Mecanismos de legitimação da jurisdição constitucional concentrada}

Como visto, o país passa por uma fase de constante abertura da jurisdição constitucional à participação da sociedade civil. Nesta segunda parte do trabalho serão estudados três instrumentos tidos como especialmente importantes para possibilitar tal participação no âmbito do controle concentrado: o rol de legitimados para propositura das ações dessa forma de controle de constitucionalidade, a audiência pública e o amicus curiae.

O amicus curiae, apesar de introduzido no ordenamento pelas Leis 9.868 e 9.882, ambas de 1999, é utilizado no processo constitucional desde antes de sua previsão legal ${ }^{66}$. Apesar de ter enfrentado uma certa resistência inicial, seu uso tem sido cada vez mais frequente, sobretudo a partir das referidas leis ${ }^{67}$.

Embora o texto legal dê a entender que se trata apenas de uma forma de trazer novas informações e argumentos para subsidiar o julgamento, tanto a doutrina quanto a jurisprudência são unânimes ao destacar uma outra função deste instrumento: permitir a ampliação da participação social nas ações de controle concentrado de constitucionalidade.

Assim, a ementa da ADI 2321-MC/DF ${ }^{68}$, publicada em 2005, traz o seguinte entendimento:

"A ideia nuclear que anima os propósitos teleológicos que motivaram a formulação da norma legal em causa, viabilizadora da intervenção do amicus curiae no processo de fiscalização normativa abstrata, tem por objetivo essencial pluralizar o debate constitucional, permitindo, desse

\footnotetext{
${ }^{66}$ Como será visto no capítulo sobre Amicus curiae.

${ }^{67}$ Conforme gráfico apresentado em trabalho de Damares Medina, por exemplo, se antes de 1999 os pedidos de ingresso como amicus curiae faziam-se presentes em menos de 5\% das ADIs propostas, vê-se que em 2000 ultrapassou 5\%, em 2003 foi superior a 15\% e em 2007 houve pedido de admissão de amicus curiae em mais de $30 \%$ das ações propostas (Amicus Curiae: Amigo da Corte ou amigo da parte? São Paulo: Saraiva, 2010, p.125). Ver também Eloísa Machado de Almeida, Sociedade civil e democracia: a participação da sociedade civil como amicus curiae no Supremo Tribunal Federal, São Paulo: tese de mestrado (Faculdade de Ciências Sociais da Pontifícia Universidade Católica de São Paulo), 2006, pp.66-68.

${ }^{68}$ Ver seção Acompanhamento Processual, no site do STF.
} 
modo, que o Supremo Tribunal Federal venha a dispor de todos os elementos informativos possíveis necessários à resolução da controvérsia, visando-se, ainda, com tal abertura procedimental, superar a grave questão pertinente à legitimidade democrática das decisões emanadas desta Suprema Corte quando no desempenho de seu extraordinário poder de efetuar, em abstrato, o controle concentrado de constitucionalidade." (Grifamos)

A doutrina compartilha desse entendimento. Elival da Silva Ramos, ao tratar da necessidade de ampliação da participação social nos procedimentos de controle de constitucionalidade judicial, afirma que “andou nessa direção o legislador infraconstitucional brasileiro, ao admitir a intervenção do amicus curiae nos processos das ações diretas de inconstitucionalidade" ${ }^{\text {69 }}$.

Nesse mesmo sentido, o Ministro Gilmar Mendes, em texto que analisa as Leis 9.868/99 e 9.882/99, afirma:

“O instituto em questão (amicus curiae), de longa tradição no direito americano, visa um objetivo dos mais relevantes: viabilizar a participação no processo de interessados afetados pelas decisões tomadas no âmbito do controle de constitucionalidade. Como há facilmente de se perceber, trata-se de medida concretizadora do princípio do pluralismo democrático que rege a ordem constitucional brasileira" 70

A audiência pública, também introduzida no ordenamento pelas Leis 9.868 e 9.882 de 1999, veio a ser convocada pela primeira vez apenas anos mais tarde, mas a partir de então tem se tornado mais constante seu uso, recebendo atenção não só de juristas mas da sociedade em geral em razão dos temas polêmicos que tratou ${ }^{71}$.

\footnotetext{
${ }^{69}$ Elival da Silva Ramos, Op. cit., pp.425-426.

${ }^{70}$ Gilmar Ferreira Mendes, "Controle de Constitucionalidade: Uma análise das leis 9868/99 e 9882/99", Revista Diálogo Jurídico, n¹1, Salvador, fev. 2002, p.5.

${ }^{71}$ Entre eles, como se verá, as pesquisas com células-tronco embrionárias, a interrupção da gestação de feto anencefálico e a instituição de cotas no ensino público superior.
} 
Assim como no caso do amicus curiae, além da função ressaltada pelo texto legal ${ }^{72}-$ de fornecer informações que subsidiem os Ministros em suas decisões - tanto a doutrina ${ }^{73}$ quanto a jurisprudência têm destacado também a de "conferir, pela abertura de participação popular na instrução de julgados, legitimação às decisões proferidas no controle concentrado" 74 .

Nas palavras do Ministro Carlos Ayres Britto quando da covocação da primeira audiência pública no âmbito do STF: "a audiência pública, além de subsidiar os Ministros deste Supremo Tribunal Federal, também possibilitará u'a maior participação da sociedade civil no enfrentamento da controvérsia constitucional, o que certamente legitimará ainda mais a decisão a ser tomada pelo Plenário desta nossa colenda Corte."75

Além desses dois instrumentos, apontados como capazes de aumentar a legitimidade democrática das decisões do STF por permitirem que a sociedade civil manifeste-se acerca dos casos, será analisado ainda o rol de legitimados para propor ações diretas de controle de constitucionalidade.

Sua ampliação, pela Constituição Federal de 1988 e suas emendas, trouxe importante contribuição para uma maior participação social nos procedimentos de controle de constitucionalidade $^{76}$, já que os legitimados não apenas se manifestam quanto ao caso em discussão, mas justamente determinam o que será discutido.

Por essa razão, a previsão de um maior número de legitimados é compreendida por parte da doutrina como o primeiro e principal passo do legislador rumo à abertura do

\footnotetext{
${ }^{72}$ Ver Diogo Rais, A sociedade e o Supremo Tribunal Federal: O caso das audiências públicas, Belo Horizonte: Fórum, 2012, p.56.

${ }^{73}$ Ver Fabrício Juliano Mendes Medeiros, "O Supremo Tribunal Federal e a primeira audiência pública de sua história”, Revista Jurídica, n. 84, v. 9, 2007; Jânia Maria Lopes Saldanha e Ângela Araújo da Silveira Espindola, "A jurisdição constitucional e o caso da ADIn 3.510: do modelo individualista - e liberal - ao modelo coletivo - e democrático - de processo", Revista de Processo, n. 154, 2007, pp.266267; Tahinah Albuquerque Martins, "Audiência Pública na Ação Direta de Inconstitucionalidade 3510/DF: Breves Considerações”, Observatório da Jurisdição Constitucional, ano 1, out. 2007, pp.14-15; Gustavo Binenbojm, A Nova Jurisdição Constitucional Brasileira - Legitimidade democrática e Instrumentos de realização, pp.176-178; Oscar Vilhena Vieria, "Supremocracia”, p.453; entre outros

${ }^{74}$ Anna Candida da Cunha Ferraz, "A projeção da democracia participativa na Jurisdição Constitucional no Brasil: As audiências públicas e sua adoção no modelo concentrado de constitucionalidade”, p.91.

${ }^{75}$ Decisão disponível em http://www.stf.jus.br/portal/jurisprudencia/visualizarEmenta.asp?s1=000025438\&base=baseMonocraticas ${ }^{76}$ Nesse sentido, ver Elival da Silva Ramos, Op.cit., pp.425-426.
} 
processo de controle de constitucionalidade ${ }^{77}$. Assim resume Luiz Vicente de Medeiros Queiroz Neto:

“A Constituição Federal de 1988 (CF/88) alterou substancialmente o modelo de controle abstrato de constitucionalidade vigente no direito brasileiro. Migrou-se de um modelo de legitimidade exclusiva, atribuição exercida pelo Procurador-Geral da República, para um modelo de legitimidade concorrente.

No art. 103, não se incluíram apenas autoridades e órgãos do Estado, mas também entes privados (IX), assegurando maior representatividade aos diversos setores da sociedade civil. Trata-se de mais uma demonstração do móvel democratizante instalado no País." ${ }^{, 78}$

A respeito da democratização proporcionada pela previsão desses novos legitimados, Fernanda Dias Menezes de Almeida e Anna Candida da Cunha Ferraz afirmam:

“A ampliação desse rol, como se disse, 'democratiza' o processo constitucional; de outro lado, a ampliação do rol de legitimados reafirma o princípio da legitimidade da jurisdição constitucional, no que respeita à proteção ao direito das minorias; finalmente, ainda que de modo indireto, permite o alargamento da proteção dos direitos fundamentais - núcleo principal de qualquer Constituição - na medida em que impede a vinculação do direito de propositura desse tipo de controle, mais eficaz e mais célere, a um ou apenas alguns entes governamentais ou mesmo políticos."79

Se na visão de boa parte da doutrina e dos próprios membros do STF, como visto, a ampliação do acesso à jurisdição constitucional concentrada, a intervenção do amicus curiae e as audiências públicas são celebrados por permitirem a ampla participação popular, capaz de minimizar o déficit democrático, faz-se necessário um cauteloso

\footnotetext{
${ }^{77}$ É dessa forma que a questão é tratada por Elival da Silva Ramos, por exemplo, ao dissertar sobre a importância da ampliação da participação nos procedimentos de controle. (Op.cit., pp.425-426.)

${ }^{78}$ Luiz Vicente de Medeiros Queiroz Neto, "A pertinência temática como requisito da legitimidade ativa para o processo objetivo de controle abstrato de normas", Revista da Fundação Escola Superior do Ministério Público do Distrito Federal e Territórios, n. 21, jan./jun. 2003, p.1.

${ }^{79}$ Fernanda Dias Menezes de Almeida, Anna Candida da Cunha Ferraz, "O constitucionalismo contemporâneo na recente jurisprudência do Supremo Tribunal Federal", Revista de Direito Constitucional e Internacional, v. 18, n. 71, São Paulo, abr./jun. 2010, pp.21-22.
} 
estudo para que se verifique se, na prática, da forma como são regulamentados pela legislação e interpretados e aplicados pelo Supremo Tribunal Federal, esses mecanismos realmente cumprem com tal função.

É nesse sentido que, ao tratar das audiências públicas, Anna Candida da Cunha Ferraz faz um alerta importante também para os demais mecanismos:

"Impõe-se, para atender aos objetivos visados, que a disciplina e a regulamentação deste instrumento devam se submeter a normas que efetivamente lhe permitam alcançar a finalidade pretendida. Esta parece ser uma 'regra de ouro' para que a abertura à participação popular, em processo tão especial quanto relevante, não se desvirtue dos fins perseguidos." ${ }^{, 80}$

Nesta parte do trabalho serão analisados os legitimados para ingressar na jurisdição constitucional concentrada, o amicus curiae e a audiência pública, com o objetivo de se verificar se na prática, da forma como são regulamentados pela legislação e interpretados e aplicados pelo Supremo Tribunal Federal, esses mecanismos realmente permitem a ampla participação popular prometida, capaz de minimizar o déficit democrático.

Assim, deve-se verificar se além da previsão das audiências públicas, sua regulamentação e utilização pelos Ministros do STF permite efetivamente a participação ampla da sociedade. Para tanto, é necessária uma análise das hipóteses em que elas são convocadas e sob qual argumento, como são escolhidos seus participantes, de que forma participam e interagem com os membros da Corte.

Serão aqui analisadas individualmente cada uma das sete audiências públicas realizadas até 31 de dezembro de 2012, período em que foram concluídas as pesquisas para este trabalho, além da doutrina disponível a respeito.

Não basta, também, a previsão do amicus curiae pela legislação, devendo-se atentar para os requisitos utilizados pelos Ministros para sua admissão e a forma como se manifestam no processo.No mesmo sentido, não é suficiente a redação de um rol amplo

\footnotetext{
${ }^{80}$ Anna Candida da Cunha Ferraz, "A Projeção da Democracia Participativa na Jurisdição Constitucional no Brasil: As Audiências Públicas e sua Adoção no Modelo Concentrado de Constitucionalidade”, p.92.
} 
de legitimados para que efetivamente haja uma abertura da jurisdição constitucional à sociedade. Deve, assim, ser estudada a definição de cada agente previsto no artigo 103 da Constituição Federal, como se dá a interpretação deste rol pelo Supremo Tribunal Federal e quais são os requisitos utilizados para a admissão dos requerentes.

Para o estudo do amicus curiae bem como dos legitimados a propor ações de controle concentrado do constitucionalidade, em razão do grande número de manifestações existentes, uma análise casuística tornaria inviável a conclusão deste trabalho. Assim, optou-se por recorrer, além da doutrina existente e de relevantes dados estatísticos, a alguns casos que permitam ilustrar as questões apresentadas.

Apesar da empolgação geral com a criação de tais institutos no processo de controle de constitucionalidade, são muitas também as críticas $^{81}$ quanto à forma com que são regulamentados e utilizados, não correspondendo à expectativa de democratizar a jurisdição constitucional. Cumpre a este trabalho considerar essas críticas na análise do papel desempenhado pela expansão do rol de legitimados a propor ações diretas de constitucionalidade, e pela criação do amicus curiae e das audiências públicas.

\footnotetext{
${ }^{81}$ Fernanda Dias Menezes de Almeida, Anna Candida da Cunha Ferraz, Op. cit., pp.24, 29; Anna Candida da Cunha Ferraz, "O acesso à Jurisdição Constitucional como caminho para a sua democratização" in Maria Elizabeth Guimarães Teixeira Rocha, Zilah Maria Callado Fadul Petersen [coord.], Coletânea de Estudos Jurídicos, Brasília: Superior Tribunal Militar, 2008, pp.494-495; Ana Letícia Queiroga de Mattos, Amicus Curiae: Hermenêutica e Jurisdição Constitucional, Belo Horizonte: Arraes, 2011, pp.185-188, 194-195, 213; Carolina Cutrupi Ferreira, "Os Critérios de Legitimidade Reconhecidos pelo STF para Propositura de Ação Direta de Inconstitucionalidade", in Diego R. Coutinho e Adriana M. Vojvodic [coord.], Jurisprudência Constitucional: Como decide o STF? São Paulo: Malheiros, 2009, pp.232-234; Carolina Elisa Suptitz, Ana Paula de Almeida Lopes, "Audiência Pública: Democracia Participativa e Plural?", Anais do XVII Congresso Nacional do CONPEDI, 2008, pp.643-645; Gilmar Ferreira Mendes, Jurisdição Constitucional: O controle abstrato de normas no Brasil e na Alemanha, 5. Ed. São Paulo: Saraiva, 2005, pp.162, 173-174, 179; Gustavo Binenbojm, A nova Jurisdição Constitucional brasileira: Legitimidade democrática e instrumentos de realização, pp.148-149; Luiz Vicente de Medeiros Queiroz Neto, Op. cit., pp.14-15, entre outros.
} 


\section{Audiência pública}

\subsection{Disciplina normativa no âmbito do Supremo Tribunal Federal}

As audiências públicas são utilizadas há tempos e com significativa frequência pelos Poderes Legislativo e Executivo. No Poder Judiciário, porém, seu uso é recente. No âmbito do Supremo Tribunal Federal, tal instrumento passou a ser previsto por lei apenas em 1999, tendo a primeira audiência pública sido realizada somente em 2007.

$\mathrm{Na}$ jurisdição constitucional concentrada, portanto, trata-se de recurso bastante recente mas cada vez mais recorrente, tendo em vista que da primeira audiência pública da história do STF até os dias de hoje ele já foi utilizado sete vezes, sendo duas vezes no ano de 2012.

As audiências públicas jurisdicionais foram inicialmente previstas pelas Leis 9.868 e 9.882, ambas de 1999, sendo aquela responsável pela regulamentação da ação direta de inconstitucionalidade e da ação declaratória de constitucionalidade, enquanto esta trata do processo e julgamento da arguição de descumprimento de preceito fundamental.

Assim, ao tratar da ação direta de inconstitucionalidade, o $\operatorname{artigo} 9^{\circ}$, $\S 1^{\circ}$, da Lei 9.868/99, que também se aplica à ação direta de inconstitucionalidade por omissão ${ }^{82}$, prevê:

“Art. 9 Vencidos os prazos do artigo anterior, o relator lançará o relatório, com cópia a todos os Ministros, e pedirá dia para julgamento.

$\S 1^{\underline{o}}$ Em caso de necessidade de esclarecimento de matéria ou circunstância de fato ou de notória insuficiência das informações existentes nos autos, poderá o relator requisitar informações adicionais, designar perito ou comissão de peritos para que emita parecer sobre a questão, ou fixar data para, em audiência pública, ouvir depoimentos de pessoas com experiência e autoridade na matéria." (Grifamos)

\footnotetext{
82 “Art. 12-E. Aplicam-se ao procedimento da ação direta de inconstitucionalidade por omissão, no que couber, as disposições constantes da Seção I do Capítulo II desta Lei.” Lei 9.869/99.
} 
Redação idêntica apresenta o artigo 20, $\S 1^{0}$, da mesma lei ao regulamentar a ação declaratória de constitucionalidade. Já o artigo $6^{\circ}, \S 1^{\circ}$, da Lei 9.882/99, ao dispor sobre a arguição de descumprimento de preceito fundamental, assim estabelece:

“Art. $6^{\circ}$ Apreciado o pedido de liminar, o relator solicitará as informações às autoridades responsáveis pela prática do ato questionado, no prazo de dez dias.

$\S 1^{\underline{0}}$ Se entender necessário, poderá o relator ouvir as partes nos processos que ensejaram a arguição, requisitar informações adicionais, designar perito ou comissão de peritos para que emita parecer sobre a questão, ou ainda, fixar data para declarações, em audiência pública, de pessoas com experiência e autoridade na matéria." (Grifamos)

Com base nesses dispositivos, é possível observar que as audiências públicas poderiam ser convocadas pelos relatores de processos de controle abstrato de constitucionalidade já instaurados no Supremo Tribunal Federal, não havendo, portanto, nenhuma regulamentação acerca da sua utilização em outras hipóteses.

Em 2009, uma alteração no Regimento Interno do Supremo Tribunal Federal trouxe a possibilidade de convocação de audiência pública para esclarecer também questões que não estivessem vinculadas a processos de controle abstrato de constitucionalidade já instaurados no Tribunal.

A previsão desta atribuição ao Presidente do $\mathrm{STF}^{83}$ encontra-se no artigo 13, XVII e XVIII do Regimento Interno:

“Art. 13. São atribuições do Presidente:

(...)

XVII - convocar audiência pública para ouvir o depoimento de pessoas com experiência e autoridade em determinada matéria, sempre que entender necessário o esclarecimento de questões ou circunstâncias de fato, com repercussão geral e de interesse público relevante, debatidas no âmbito do Tribunal.

\footnotetext{
${ }^{83}$ Não fica claro se poderá o Presidente do STF convocar audiência pública, entendendo necessário, ainda que seja para auxiliar na decisão de uma ação que tenha como Relator outro Ministro, que não julgou necessário o uso desse instrumento. Em verdade, se esse entendimento fosse possível, estar-se-ia dando ao Presidente poderes que não são previstos ao se analisar todo o restante do texto do Regimento Interno. Além disso, tal interpretação geraria interferência considerável nas funções designadas ao Ministro Relator, razão pela qual entendo não ser cabível.
} 
XVIII - decidir, de forma irrecorrível, sobre a manifestação de terceiros, subscrita por procurador habilitado, em audiências públicas ou em qualquer processo em curso no âmbito da Presidência."

Já o artigo 21, incisos XVII e XVIII do Regimento Interno do STF, atribuiu ao Ministro Relator, mesmo nos casos não previstos nas hipóteses das Leis 9868/99 e 9882/99, acima reproduzidas, a competência para convocar audiência quando julgar necessário e de decidir, de maneira irrecorrível, sobre a participação de terceiros nesta:

“Art. 21. São atribuições do Relator:

$(\ldots)$

XVII - convocar audiência pública para ouvir o depoimento de pessoas com experiência e autoridade em determinada matéria, sempre que entender necessário o esclarecimento de questões ou circunstâncias de fato, com repercussão geral ou de interesse público relevante.

XVIII - decidir, de forma irrecorrível, sobre a manifestação de terceiros, subscrita por procurador habilitado, em audiências públicas ou nos processos de sua relatoria."

Vê-se, portanto, que, pelos requisitos previstos nos textos legais e nos artigos do Regimento Interno supracitados, são quatro as hipóteses de convocação de audiência pública:

1) Para ADI, ADI por omissão e ADC (Art. $9^{\circ}, \S^{\circ} 1^{\circ}$ e Art. 20, $\S^{\circ}{ }^{\circ}$ da Lei 9.868/99): Em caso de necessidade de esclarecimento de matéria ou de circunstância de fato, ou em havendo notória insuficiência das informações existentes nos autos, para que sejam ouvidas pessoas com experiência e autoridade na matéria. A convocação, nesses casos, será faculdade do Relator da ação;

2) Para $\operatorname{ADPF}\left(6^{\circ}, \S 1^{\underline{0}}\right.$, da Lei 9.882/99): Em havendo necessidade, para que sejam ouvidas pessoas com experiência e autoridade na matéria. A convocação aqui também será faculdade do Ministro Relator;

3) Para qualquer espécie de ação ou recurso que tramite no STF (Art. 21, incisos XVII e XVIII do Regimento Interno do STF): Quando for necessário o esclarecimento de questões ou circunstâncias de fato, com repercussão geral e de interesse público relevante, para que sejam ouvidas pessoas com 
experiência e autoridade na matéria. A convocação da audiência, nesta hipótese, será faculdade do Relator da ação;

4) Para a discussão de matéria debatida no âmbito do Tribunal, porém desvinculada de um caso específico (Art. 13, inciso XVII do Regimento Interno do STF): Sempre que entender necessário o esclarecimento de questões ou circunstâncias de fato, com repercussão geral e de interesse público relevante, para ouvir o depoimento de pessoas com experiência e autoridade na matéria. Nessa hipótese, a convocação será faculdade do Presidente do STF.

Além de trazer nova hipótese de convocação de audiência, a Emenda Regimental n.29 de 2009 trouxe, enfim, ainda que minimamente, alguma regulamentação à matéria, já que, até então, embora previsto em lei, não existia qualquer dispositivo normativo tratando o modo de convocação e de realização deste instituto.

Assim, o artigo 154, parágrafo único do Regimento trouxe as seguintes determinações:

“Art. 154. Serão públicas as audiências:

(...)

III - para ouvir o depoimento das pessoas de que tratam os artigos 13, inciso XVII, e 21, inciso XVII, deste Regimento.

Parágrafo único. A audiência prevista no inciso III observará o seguinte procedimento:

I - o despacho que a convocar será amplamente divulgado e fixará prazo para a indicação das pessoas a serem ouvidas;

II - havendo defensores e opositores relativamente à matéria objeto da audiência, será garantida a participação das diversas correntes de opinião;

III - caberá ao Ministro que presidir a audiência pública selecionar as pessoas que serão ouvidas, divulgar a lista dos habilitados, determinando a ordem dos trabalhos e fixando o tempo que cada um disporá para se manifestar;

IV - o depoente deverá limitar-se ao tema ou questão em debate;

V - a audiência pública será transmitida pela TV Justiça e pela Rádio Justiça; 
VI - os trabalhos da audiência pública serão registrados e juntados aos autos do processo, quando for o caso, ou arquivados no âmbito da Presidência;

VII - os casos omissos serão resolvidos pelo Ministro que convocar a audiência."

Todas as demais questões procedimentais não tratadas no Regimento deverão ser resolvidas, no caso concreto, pelo ministro que presidir a audiência pública, da forma que melhor entender, como consta no último inciso do artigo supracitado.

\subsection{Definição}

Do acima disposto, pode-se concluir, de forma sucinta, que as audiências públicas jurisdicionais são instrumentos que possibilitam que os Ministros ouçam os depoimentos de pessoas com experiência e autoridade em determinado tema debatido no âmbito do Tribunal, quando entenderem necessário algum esclarecimento de matéria ou de circunstância de fato, ou ainda quando as informações existentes nos autos forem insuficientes para o julgamento.

Na elaborada definição apresentada por Anna Candida da Cunha Ferraz, trata-se de "instrumento de abertura democrática no exercício da interpretação e da jurisdição constitucional concentrada", sendo "convocada pelo órgão supremo da jurisdição constitucional para instrução, particularmente fática, de processos constitucionais que têm como tema central assuntos de grande ressonância social e com relação aos quais a participação de especialistas no ramo para prestar esclarecimentos técnicos e fáticos é considerada forma de informação desejável para os magistrados que devem decidir uma questão sob o ângulo jurídico" 84 .

Importante ressaltar, desse conceito, a ideia de que o instituto visa a esclarecer matéria ou circunstância de fato, o que, para a autora, "parece afastar a possibilidade de, em sede de audiência pública, questionar-se fundamentos jurídicos para embasar a decisão

\footnotetext{
${ }^{84}$ Anna Candida da Cunha Ferraz, "A Projeção da Democracia Participativa na Jurisdição Constitucional no Brasil: As Audiências Públicas e sua Adoção no Modelo Concentrado de Constitucionalidade”, p.88.
} 
judicial sobre a problemática existente nos autos" ${ }^{\Perp 85}$. É esse também o entendimento defendido neste trabalho, embora a questão não seja pacífica ${ }^{86}$.

Como se pôde perceber, a lei traz a audiência pública como um instrumento para aumentar a legitimidade técnica das decisões do Tribunal, já que, em todas as hipóteses acima analisadas, prevê a participação de pessoas com experiência e autoridade na matéria discutida.

Entretanto, por permitir que o Supremo Tribunal Federal ouça pessoas que não teriam outra possibilidade de participar do controle concentrado de constitucionalidade $^{87}$, a criação das audiências públicas foi festejada por parte da doutrina, que diante dos cada vez mais presentes questionamentos quanto a ausência de legitimidade do Tribunal, destacou a sua importância para a abertura da jurisdição constitucional concentrada à sociedade.

Reflete essa empolgação o conceito de audiência pública construído por Diogo Rais:

“Audiência pública no âmbito do Supremo Tribunal Federal é o instrumento pelo qual essa Corte ouve o público especializado ou dotado de experiência na matéria para esclarecer questões ou circunstâncias de fato, com repercussão geral ou de interesse público relevante, com a finalidade de esclarecer os Ministros sobre a matéria ou circunstâncias de fato, além de criar oportunidade para se debater simultaneamente as teses opostas e com fundamentos variados, ampliando e fomentando o debate dentro e fora da Corte, ampliando a transparência e a publicidade das atividades do Supremo Tribunal Federal e trazendo maior pluralidade ao processo constitucional, além de aproximar a sociedade da Corte e, ainda, possibilitar a aferição de

\footnotetext{
${ }^{85}$ Anna Candida da Cunha Ferraz, “A Projeção da Democracia Participativa na Jurisdição Constitucional no Brasil: As Audiências Públicas e sua Adoção no Modelo Concentrado de Constitucionalidade”, p.93.

${ }^{86}$ Há quem não faça tal distinção e, por isso, entenda que os institutos do amicus curiae e da audiência pública se confundem. As diferenças entre os dois instrumentos serão melhor tratadas no capítulo referente ao Amicus curiae.

${ }^{87}$ Os requisitos para propositura de ações de controle concentrado de constitucionalidade e para ingresso como amicus curiae - outras formas de participação na jurisdição constitucional concentrada - serão tratados nos capítulos seguintes.
} 
efeitos do julgado, realizando um prognóstico do comportamento social diante da decisão a ser tomada." 88

Para que todas essas características possam ser creditadas às audiências públicas, entretanto, faz-se necessário um estudo não só do tratamento legal dado a este instituto, como também da forma como sua regulamentação é aplicada pelos Ministros e de como elas são, na prática, organizadas.

Como se pôde observar, as Leis 9.868 e 9.882 de 1999, responsáveis por incorporar legalmente as audiências públicas nos processos constitucionais, não apresentaram qualquer disposição em relação ao seu procedimento. A alteração regimental n. 29 de 2009, por sua vez, embora tendo traçado uma mínima regulamentação do procedimento de convocação e regulamentação da audiência pública, deixou questões importantes para sua estruturação a critério do Ministro responsável por presidi-lo - ou seja, o relator nos casos vinculados a processos ou o presidente do tribunal nas hipóteses em que não há vinculação a um processo.

Esse alto grau de discricionariedade atribuído aos Ministros faz com que as audiências realizadas possam tomar rumos diversos, dependendo do que determinar quem a presidir.

Assim, para a real compreensão de seu funcionamento e do papel que podem desempenhar, é essencial uma análise empírica das audiências públicas já realizadas, trabalho este que será realizado a seguir.

\subsection{Histórico das audiências públicas realizadas}

Desde a previsão legal das audiências públicas pelo STF até o final de 2012, essas já foram realizadas pelo Tribunal em sete oportunidades ${ }^{89}$.

\footnotetext{
${ }^{88}$ Diogo Rais, A sociedade e o Supremo Tribunal Federal: o caso das audiências públicas, p.48.

${ }^{89}$ Em outras três oportunidades, ainda em 2012, foram convocadas audiências: uma para auxiliar o julgamento de três ações diretas de inconstitucionalidade (de números 4.679, 4.747 e 4.756) e as outras duas para auxiliar o julgamento de recursos extraordinários. Porém, como as pesquisas empíricas para
} 
A primeira audiência pública da história do Supremo Tribunal Federal foi realizada apenas em 20 de abril de 2007, provocada por solicitação da Procuradoria-Geral da República, que, à época, movia a ação direta de inconstitucionalidade $\mathrm{n}^{\circ} 3.510$ contra o artigo $5^{\circ}$ da Lei $n^{\circ} 11.105 / 05$. Este artigo permitia a realização de pesquisas com células-tronco embrionárias humanas desde que, inviáveis ou congeladas há 3 anos ou mais, houvesse o consentimento de seus genitores e a aprovação da pesquisa por uma comissão de ética.

A Procuradoria entendeu que o referido artigo da Lei de Biossegurança feria o direito à vida e à dignidade da pessoa humana, uma vez que defendeu nessa ação a tese de que a vida humana acontece a partir da fecundação. Partindo-se desse pressuposto, portanto, a destruição de embriões humanos para utilização em pesquisas atentaria contra o direito à vida.

Sendo a matéria objeto da ação transdisciplinar, por englobar questões jurídicas mas também científicas, religiosas e éticas, optou o Ministro Carlos Ayres Britto, relator do processo, por atender ao pedido do Procurador-Geral da República e convocar a primeira audiência pública daquele Tribunal.

Em 27 de junho de 2008 o STF realizou sua segunda audiência pública, por determinação da Relatora da arguição de descumprimento de preceito fundamental $\mathrm{n}^{\circ}$ 101, a Ministra Cármen Lúcia.

A referida ação, ajuizada pelo Presidente da República, contestava a constitucionalidade de decisões judiciais que permitiam a importação de pneus usados, o que, no entendimento do arguente, feriria os direitos à saúde e a um meio ambiente ecologicamente equilibrado, além de afrontar Portarias do Departamento de Operações de Comércio Exterior (Decex) e da Secretaria de Comércio Exterior (Secex), Resoluções do Conselho Nacional do Meio Ambiente (Conama), além de Decretos Federais.

este trabalho foram concluídas em 31 de dezembro de 2012, as audiências convocadas mas não realizadas até a citada data não serão aqui analisadas. 
Por entender que a matéria objeto desta ADPF envolvia não apenas questões jurídicas, mas também relativas ao meio ambiente, à saúde, à economia e até mesmo às relações internacionais do Brasil, e tendo em vista a repercussão social do tema, a Ministra Cármen Lúcia convocou esta audiência.

Entre agosto e setembro do ano de 2008, esse recurso foi novamente utilizado, desta vez em razão da arguição de descumprimento de preceito fundamental $\mathrm{n}^{\circ} 54$, ajuizada pela Confederação Nacional dos Trabalhadores da Saúde (CNTS).

A ação discutia a permissão da interrupção da gestação no caso de anencefalia do feto. $\mathrm{O}$ arguente defendia a tese de que a proibição da antecipação terapêutica do parto em caso de fetos anencefálicos feriria preceitos fundamentais como os princípios da dignidade da pessoa humana e da legalidade, bem como os direitos à liberdade e à saúde.

O requerimento da audiência pública foi feito pelo Procurador-Geral da República, contrário à tese do arguente, e atendido pelo relator do processo, o Ministro Marco Aurélio, que antes mesmo desse pedido já havia manifestado seu interesse ${ }^{90}$ em fazer uso desse procedimento, tendo em vista os conhecimentos específicos necessários para o julgamento do caso.

A quarta audiência pública realizada pelo STF diferiu das demais por não ter sido convocada para auxiliar no julgamento de uma ação específica, como até o momento havia ocorrido, sendo, dessa forma, convocada pelo então Presidente da Corte, o Ministro Gilmar Mendes.

O Ministro valeu-se da então recente alteração do Regimento Interno do STF, que em seu artigo 13, XVII incluiu entre as atribuições do Presidente do Tribunal a de convocar audiência pública sempre que entender necessário o esclarecimento de questões debatidas em seu âmbito, havendo repercussão geral e interesse público relevante.

Entendendo que era esse o contexto e que a realização da audiência seria necessária, entre abril e maio de 2009 o Ministro utilizou-se desse instrumento visando a esclarecer questões referentes à responsabilidade dos entes federados em matéria de direito à 
saúde, às obrigações do Estado de fornecer prestação de saúde prescrita por médico que não pertence ao SUS ou sem que o pedido tenha sido feito previamente à Administração Pública, de custear as prestações de saúde que não são contempladas pelas políticas públicas existentes, de fornecer medicamentos ou tratamentos experimentais não registrados na ANVISA ou não aconselhados pelos Protocolos Clínicos do SUS, de fornecer medicamento não licitado e que não integre a lista do SUS e, ainda, a discutir os problemas referentes às fraudes ao SUS. ${ }^{91}$

Embora não tenha sido convocada visando a auxiliar no julgamento de um caso específico, diversas ações já foram julgadas pelo STF com base nas informações obtidas a partir da audiência pública sobre a saúde. É o caso, por exemplo, dos agravos regimentais nas Suspensões de Tutela Antecipada (STA) 175, 211 e 278, nas Suspensões de Segurança (SS) 3.724, 2.944, 2.361, 3.345 e 3.355, e na Suspensão de Liminar (SL) 47.

Vale ressaltar que todas essas ações, conforme determina o Regimento Interno do Supremo Tribunal Federal ${ }^{92}$, são de competência do Presidente do STF, ou seja, ainda que as audiências públicas estivessem vinculadas a esses casos, o Ministro Gilmar Mendes seria o responsável pela sua convocação e organização, uma vez que ocupando a presidência do tribunal, ele seria o Ministro Relator desses casos.

Em março de 2010 foi a vez da realização de nova audiência, dessa vez por determinação do Ministro Ricardo Lewandowski, relator da arguição de descumprimento de preceito fundamental $\mathrm{n}^{\circ} 186$ e do recurso extraordinário $\mathrm{n}^{\circ}$ $597.285 / \mathrm{RS}$.

\footnotetext{
91 "Audiência Pública para ouvir o depoimento de pessoas com experiência e autoridade em matéria de Sistema Único de Saúde, objetivando esclarecer as questões técnicas, científicas, administrativas, políticas, econômicas e jurídicas relativas às ações de prestação de saúde, tais como:

1) Responsabilidade dos entes da federação em matéria de direito à saúde;

2) Obrigação do Estado de fornecer prestação de saúde prescrita por médico não pertencente ao quadro do SUS ou sem que o pedido tenha sido feito previamente à Administração Pública;

3) Obrigação do Estado de custear prestações de saúde não abrangidas pelas políticas públicas existentes;

4) Obrigação do Estado de disponibilizar medicamentos ou tratamentos experimentais não registrados na ANVISA ou não aconselhados pelos Protocolos Clínicos do SUS;

5) Obrigação do Estado de fornecer medicamento não licitado e não previsto nas listas do SUS;

6) Fraudes ao Sistema Único de Saúde.” Despacho de convocação da audiência pública, disponível em http://www.stf.jus.br/arquivo/cms/processoAudienciaPublicaSaude/anexo/Despacho_Convocatorio.pdf

${ }^{92}$ Ver art. 297 do Regimento Interno do STF.
} 
No primeiro caso, a ação foi proposta pelo Partido Democratas (DEM) contra atos administrativos que resultaram na utilização de critérios raciais para programas de admissão na Universidade de Brasília (UnB).

Já o recurso extraordinário foi interposto contra acórdão do Tribunal Regional Federal da $4^{\text {a }}$ Região ${ }^{93}$ que julgou constitucional o sistema de reserva de vagas estabelecido pela Universidade Federal do Rio Grande do Sul (UFRGS) como forma de ação afirmativa. O recorrente, Giovane Pasqualito Fialho, não foi aprovado no exame para ingresso em curso superior, embora tivesse alcançado pontuação maior do que alguns candidatos admitidos no mesmo curso pelo sistema de reserva de vagas destinadas aos estudantes vindos do ensino público.

Em ambos os casos alegou-se, portanto, que a política de reserva de vagas feriria os princípios da dignidade da pessoa humana e da igualdade, o direito à educação, além de outros dispositivos previstos no texto constitucional ${ }^{94}$. Aproveitando o tema comum, o Ministro convocou audiência pública para auxilixar no processo decisório dos dois casos.

Em 2012 foram realizadas outras duas audiências no âmbito do STF, tendo a primeira delas ocorrido em maio. Tal audiência foi convocada pelo Ministro Luiz Fux em razão da ação direta de inconstitucionalidade $\mathrm{n}^{\circ} 4.103$.

Essa ação foi proposta pela Associação Brasileira de Restaurantes e Empresas de Entretenimento (ABRASEL) e questionava a constitucionalidade dos artigos $2^{\circ}, 4^{\circ}$ e $5^{\circ}$, incisos III, IV e VIII, da Lei n. 11.705/08, também conhecida como "Lei Seca". Tais artigos tratam da proibição da venda de bebidas alcoólicas à beira das rodovias federais ou em terrenos contíguos à faixa de domínio com acesso direto à rodovia, prevendo punição para os infratores bem como para o estabelecimento comercial, dispõem sobre a fiscalização do cumprimento da lei pela Polícia Rodoviária Federal e pelos Estados, Distrito Federal e Municípios, além de alterarem o Código de Trânsito Brasileiro,

\footnotetext{
${ }^{93}$ Acórdão disponível em http://redir.stf.jus.br/estfvisualizadorpub/jsp/consultarprocessoeletronico/ConsultarProcessoEletronico.jsf ?seqobjetoincidente $=2662983$

94 "Os dispositivos tidos por afrontados são os artigos $1^{\circ}$, caput e III, $3^{\circ}$, IV, $4^{\circ}$, VIII, $5^{\circ}$, I, II, XXXIII, XLII e LIV, 37, caput, 205, 206, caput e I, 207, caput, e 208, V, da_Constituição Federal.” Despacho convocatório de audiência pública disponível em http://www.stf.jus.br/portal/cms/verTexto.asp?servico=processoAudienciaPublicaAcaoAfirmativa.
} 
estabelecendo limite máximo de concentração de álcool no organismo, delegando competência para que agentes de trânsito caracterizem a embriaguez, prevendo a mesma punição estabelecida a um condutor em embriaguez extrema àquele que se nega a produzir prova contra si, e aumentando a pena para quem dirige sob influência de álcool ou substância de efeitos análogos.

Alegou-se que tais dispositivos feririam os princípios constitucionais da isonomia, da razoabilidade, da livre iniciativa, da liberdade econômica, da mínima intervenção estatal, bem como o direito adquirido.

Diante desse embate, o Ministro Luiz Fux decidiu convocar audiências públicas por entender que a temática versada na ação reclamava "apreciação que ultrapassa os limites do estritamente jurídico, porquanto demanda abordagem técnica e interdisciplinar da matéria"95 e trouxe no despacho convocatório uma série de questões técnicas e fáticas que deveriam ser esclarecidas pelos expositores ${ }^{96}$.

No mesmo ano, ao final do mês de agosto, realizou-se audiência na ação direta de inconstitucionalidade $n^{\circ} 3.937$, proposta pela Confederação Nacional dos Trabalhadores da Indústria (CNTI) para impugnar a Lei no 12.684/07, do Estado de São Paulo, que proíbe o uso de produtos materiais ou artefatos que contenham qualquer tipo de amianto ou asbesto em sua composição.

Defendeu-se que a referida lei, além de ferir o princípio constitucional da livre iniciativa, invadiu competência legislativa da União, contrariando legislação federal já

95 Notícia veiculada no site do STF em 05/12/11, disponível em http://www.stf.jus.br/portal/cms/verNoticiaDetalhe.asp?idConteudo=195462\&caixaBusca=N

96 "As Audiências serão realizadas para que, em essência, os expositores esclareçam os seguintes tópicos: i) efeitos da bebida alcoólica na condução de veículos automotores; ii) efeitos no aumento do número de acidentes em rodovias, em razão da venda de bebidas alcoólicas nas proximidades de rodovias; iii) se a Lei $n^{\circ} 11.705$ (Lei Seca) já trouxe benefícios concretos para a população brasileira; iv) meios científicos, invasivos e não invasivos, para se apurar, com segurança, a embriaguez incapacitante para a condução de veículos; v) número de prisões e autuações administrativas efetuadas após o surgimento da "Lei Seca", em razão da condução de veículos em estado de embriaguez; vi) panorama mundial do enfrentamento do problema da embriaguez ao volante; vii) se a concentração de álcool por litro de sangue igual ou superior a 6 (seis) decigramas gera, em qualquer pessoa, e independentemente da sua compleição física, um estado de embriaguez incapacitante para a condução de um veículo; viii) se existe alguma concentração específica de álcool por litro de sangue capaz de atestar uma embriaguez incapacitante, de toda e qualquer pessoa, para a condução de um veículo automotor; ix) de que modo o aparelho conhecido como bafômetro mede a quantidade de álcool por litro de sangue igual ou superior a 6 (seis) decigramas; $\mathrm{x}$ ) a margem de erro de cada um dos métodos atualmente empregados para aferir a embriaguez ao volante; xi) a frequência de aferição dos equipamentos utilizados na medição dos níveis de alcoolemia; xii) se quem come um doce com licor, ingere um remédio com álcool ou usa um antisséptico bucal pode dar origem a uma concentração de álcool por litro de sangue igual ou superior a 6 (seis) decigramas." Documento disponível em http://www.stf.jus.br/portal/autenticacao/ sob o número 1570267. 
existente. Assim, teria afrontado também o princípio fundamental da Federação, a segurança jurídica e o sub-princípio do Estado Democrático de Direito.

A requisição da audiência foi feita pelo Instituto Brasileiro de Crisotila (IBC), amicus curiae na referida ação, sendo admitida pelo Ministro Relator, Marco Aurélio, sob a justificativa de que "Sob todos os títulos, a questão é momentosa, suscitando enfoques diversificados. Daí a conveniência de abrir-se a discussão democrática sobre a controvérsia" $"$.

\subsection{Procedimento}

Se a legislação pouco fala sobre como as audiências públicas devem ser conduzidas, a estrutura desses eventos acaba sendo definida na prática, com a realização de cada uma delas, o que ressalta a importância da análise empírica de diversos aspectos relacionados a esses eventos.

Assim, serão descritos os procedimentos adotados em cada uma das audiências realizadas para que as informações colhidas subsidiem a análise crítica e a conclusão deste capítulo, que visam verificar se e de que forma esse instrumento pode contribuir com o acréscimo de legitimidade democrática às decisões do STF.

Nos próximos itens, portanto, serão examinadas as seguintes questões: quem propõe a convocação da audiência pública e sob quais argumentos; quais os modos de participação da sociedade; qual a forma de escolha dos participantes; quem são os expositores; como se dá a organização das exposições; de que maneira os Ministros interagem com os participantes.

\subsubsection{Convocação}

Inicialmente, faz-se necessário ressaltar a diferença entre convocar a audiência pública e requerê-la. Apesar de apenas o Ministro Relator e o Presidente do STF poderem convocá-la, a iniciativa de fazer uso desse instrumento nem sempre parte deles, ou seja, ainda que os despachos convocatórios sejam por eles emitidos, os legitimados nem

97 Despacho convocatório, disponível em http://www.stf.jus.br/portal/autenticacao/ sob o número 1979625. 
sempre agem de ofício. É possível que uma das partes ou mesmo algum amicus curiae solicite a realização da audiência, ficando a critério do Ministro atender ou não à solicitação.

Na maior parte das audiências até então realizadas, como já visto, a convocação foi feita de ofício. Assim ocorreu quando tal instrumento serviu para subsidiar o julgamento das ações referentes à importação de pneus usados, à reserva de vagas em ensino superior, à saúde pública e à "Lei Seca".

A principal justificativa para a convocação, nesses casos, foi a legitimidade técnica que a oitiva dos expositores poderia fornecer, já que as ações não tratavam apenas de questões jurídicas, mas também questões técnicas relativas a outras áreas que não são de conhecimento dos membros do Supremo.

Esse argumento pode ser encontrado nos despachos convocatórios de todas as audiências acima citadas, com exceção daquela que tratou do sistema de "cotas" no ensino superior, que apenas destacou a relevância jurídica e a imensa repercussão social do tema.

O papel de contribuir com a legitimidade democrática do Tribunal foi destacado apenas no despacho convocatório da audiência que tratou da chamada "Lei Seca", que teve como relator o Ministro Luiz Fux.

Nas demais audiências públicas jurisdicionais realizadas, a convocação foi feita à pedido de algum interessado. Assim ocorreu com aquelas que discutiram as pesquisas com células-tronco embrionárias, a interrupção de gestação de feto anencéfalo e o uso de produtos com amianto em sua composição.

Conforme já mencionado, nos dois primeiros casos a solicitação partiu do Procurador Geral da República. Seja como autor na ADI 3.510 ou como custus legis na ADPF 54, em nenhum dos casos preocupou-se a Procuradoria em justificar seu pedido, limitandose a citar os artigos da legislação que trazem a previsão da audiência nessas ações.

A convocação da audiência referente à ADPF 54, todavia, deu-se de modo curioso. Ela já havia sido indicada como oportuna pelo próprio Ministro relator em $2004^{98}$ - quando, embora já prevista por lei, nenhuma audiência pública tinha sido sequer convocada pelo

\footnotetext{
${ }^{98}$ Ver decisão de 28/09/2004 disponível na seção Acompanhamento Processual do site do STF.
} 
STF -, foi requerida pelo Procurador-Geral da República no ano seguinte ${ }^{99}$, e apenas em 2008 foi convocada pelo mesmo relator ${ }^{100}$, que fez referência a esses dois momentos no despacho convocatório.

Já no caso da audiência sobre a proibição do uso de produtos com amianto em sua composição, ela foi solicitada na mesma semana pelo Instituto Brasileiro de Crisotila, amicus curiae na ADI 3.937 e pela Confederação Nacional dos Trabalhadores na Indústria, autora da ação.

Enquanto o primeiro apresentou em sua petição apenas os argumentos contrários à lei questionada e concluiu solicitando a audiência "para amplo debate da matéria, à vista de sua incontestável complexidade, assegurando-se, dessa maneira, o democrático pluralismo dessa discussão constitucional" ${ }^{\text {101 }}$, o segundo empenhou-se em demonstrar a repercussão geral e o interesse público relevante do tema controvertido, bem como a necessidade de esclarecimentos técnicos específicos, pedindo pela designação da audiência para "viabilizar o amplo debate da matéria"102.

A decisão do Ministro relator fez referência apenas ao primeiro pedido, do Instituto Brasileiro de Crisotila, e determinou a realização da audiência por entender que "a questão é momentosa, suscitando enfoques diversificados. Daí a conveniência de abrirse a discussão democrática sobre a controvérsia"103.

Após a designação da audiência, a Associação Brasileira das Indústrias e Distribuidores de Produtos de Fibrocimento (ABIFIBRO), admitida como amicus curiae na referida ação, interpôs agravo regimental contra a decisão alegando estarem ausentes os pressupostos para convocação da audiência pública, uma vez que os elementos constantes do processo já seriam suficientes para a apreciação da causa, além de não terem sido revelados os tópicos a serem debatidos, o que feriria o artigo 154 do Regimento Interno do STF.

\footnotetext{
${ }^{99}$ Ver petição de 23/05/2005 disponível na seção Acompanhamento Processual do site do STF.

${ }^{100}$ Decisão de 31/07/2008 disponível em http://www.stf.jus.br/arquivo/cms/processoAudienciaPublicaAdpf54/anexo/adpf54audiencia.pdf ${ }^{101}$ Ver petição de 30/04/12 disponível em http://redir.stf.jus.br/estfvisualizadorpub/jsp/consultarprocessoeletronico/ConsultarProcessoEletronico.jsf ?seqobjetoincidente $=2544561$.

${ }^{102}$ Ver petição de 03/05/12 disponível em http://redir.stf.jus.br/estfvisualizadorpub/jsp/consultarprocessoeletronico/ConsultarProcessoEletronico.jsf ?seqobjetoincidente $=2544561$.

${ }_{103}$ Despacho convocatório disponível em http://www.stf.jus.br/portal/autenticacao/ sob o número 1979625.
} 
Foi negado seguimento ao recurso por entender o Ministro, conforme posição já sustentada pelo Tribunal, que os amici curiae não possuem legitimidade para a interposição de recursos ou formulação de pedidos incidentais.

É importante lembrar que a convocação das audiências fica a critério exclusivamente do Ministro Relator, ainda que preenchidos todos os requisitos. Por esse motivo, existem ações em que as partes ou outros interessados solicitaram sua realização mas não foram $\operatorname{atendidos}^{104}$.

\subsubsection{Escolha dos expositores}

A forma como são escolhidos os participantes tem grande influência nos rumos que a audiência irá tomar. Se é verdade que, de acordo com o Regimento Interno, essa escolha fica a critério do Ministro que presidir a audiência, também se pode constatar que eles têm estabelecido dois modelos de escolha dos expositores.

Em três das sete audiências realizadas pelo STF até o final dessa pesquisa - audiência sobre o SUS, ADPF 186 e ADI 4.103 -, optou-se por abrir as portas do Tribunal a todo e qualquer interessado, permitindo a inscrição desses, dentro de prazo determinado, mediante endereço eletrônico divulgado no despacho convocatório. Passado o prazo, divulgou-se a lista com aqueles que foram habilitados, exercendo então o relator sua discricionariedade ao selecionar, entre todos os incritos, quais terão a oportunidade de participar.

Já pelo modelo adotado nas demais audiências - ADI 3.510, ADPF 101, ADPF 54 e ADI 3.937 -, a indicação de participantes ficou a cargo apenas do autor, dos requeridos e de interessados, como aqueles admitidos como amici curiae, não havendo, portanto, uma ampla abertura à sociedade civil. Também coube ao relator, nesse caso, admitir ou não aqueles que foram indicados.

\footnotetext{
${ }^{104}$ É o caso da ADI 3239, ADPF 153, ADI 3880, ADI 4439, entre outras. Enquanto na ADI 3.880 o Relator argumentou que as informações constantes dos autos já seriam suficientes para o julgamento, não sendo necessária a realização da audiência, nos demais casos o Relator sequer se manifestou acerca dos pedidos de realização de audiência pública.
} 
Embora possamos estabelecer essas como as duas principais formas de escolha de expositores observadas, cada audiência apresentou suas particularidades.

Na primeira experiência do STF em audiências públicas, para subsidiar o julgamento da ADI 3.510, a indicação de participantes ficou a cargo do autor, dos requeridos e dos amici curiae, que deveriam também apresentar as qualificações profissionais de seus indicados.

Ainda na petição inicial da ação direta de inconstitucionalidade, a Procuradoria-Geral da República, ao solicitar a realização da audiência pública, formulou lista com o nome de nove especialistas ${ }^{105}$ a serem ouvidos. Essa relação foi alterada ${ }^{106}$ após a convocação feita pelo Ministro Carlos Ayres Britto, Relator do caso.

A Presidência da República e o Congresso Nacional também indicaram participantes, bem como os amici curiae admitidos ${ }^{107}$ à época da decisão que determinou a intimação dos especialistas habilitados.

Já na segunda audiência realizada, que tratou da importação dos pneus, o despacho convocatório referia-se apenas aos amici curiae como legitimados a apontarem especialistas para participar da audiência. Apesar de não ter sido mencionado nesse despacho, o Presidente da República, autor da ADPF 101, apontou nove especialistas para integrarem o grupo contrário à importação de pneus.

Considerando muitos os indicados, a Ministra Cármen Lúcia, Relatora do caso, decidiu que os interessados deveriam chegar a um consenso sobre os participantes. Não havendo consenso, a alternativa seria a realização de um sorteio, no início da audiência, selecionando apenas quatro representantes de cada grupo ${ }^{108}$ para se apresentarem. Tendo ocorrido o sorteio, já que não foi possível entrar em consenso, foram selecionados não oito, mas onze especialistas habilitados a falar.

105 Disponível em http://redir.stf.jus.br/paginadorpub/paginador.jsp?docTP=TP\&docID=594135\#2\%20\%20Peticao\%20inicial .

${ }^{106}$ Ver a seção Acompanhamento Processual no site do STF em 10/04/2007.

${ }^{107}$ A ANIS - Instituto de Bioética, Direitos Humanos e Gênero e a CNBB - Conferência Nacional dos Bispos do Brasil foram aceitas como amicus curiae após a convocação dos habilitados, e, embora tenham indicados especialistas, não é possível afirmar, com base nas informações disponíveis, se foram atendidos.

${ }^{108}$ A relatora decidiu dividir os expositores em dois grupos: favoráveis e contrários à importação de pneus. Tal divisão será analisada neste trabalho, posteriormente. 
A audiência pública que tratou da antecipação terapêutica do parto de fetos anencefálicos, apesar de ter adotado o segundo modelo de escolha de participantes apresentado - indicação de expositores pelo autor, requeridos e interessados -, diferenciou-se das até então realizadas já que o próprio Relator foi responsável por grande parte das indicações de participantes.

O despacho convocatório emitido pelo relator, Ministro Marco Aurélio, propôs a oitiva de representantes das entidades já habilitadas como amici curiae e convidou outros expositores $^{109}$, escolhidos pelo próprio Ministro. Curioso notar que não há nesse documento qualquer referência à possibilidade de participação de outros que não os ali mencionados ${ }^{110}$, ou seja, inicialmente, apenas aqueles determinados pelo Relator é que poderiam participar.

Além disso, o despacho mostra que, antes mesmo da convocação, foi solicitada pelo Procurador-Geral da República, em petição que requeria também a realização da audiência pública, a participação de oito professores por ele escolhidos ${ }^{111}$, sem determinar suas respectivas áreas de atuação. Esse último pedido foi indeferido no próprio despacho pelo Ministro Relator, que alegou ter considerado a questão da conveniência, tratada pela Lei $n^{\circ}$ 9882/99, e que "a relação de entidades mencionadas (por ele escolhidas e apresentadas no documento) já revela a audição sob os diversos ângulos envolvidos na espécie" ${ }^{112}$.

Posteriormente, o Procurador-Geral da República apontou quatro profissionais a serem ouvidos, dessa vez devidamente credenciados. A solicitação foi aceita pelo Relator ${ }^{113}$, com exceção de um dos expositores, Rodolfo Acatauassú Nunes, que já havia se

\footnotetext{
${ }^{109}$ Ver despacho convocatório disponível em http://www.stf.jus.br/arquivo/cms/processoAudienciaPublicaAdpf54/anexo/adpf54audiencia.pdf .

${ }^{110}$ Isso não impediu, porém, que fossem feitos pedidos de participação, alguns deferidos e outros não, como se verá a seguir.

${ }^{111}$ Não é possível, com base nos documentos disponíveis, determinar quem foram os indicados.

${ }^{112}$ Ver despacho diponível em http://www.stf.jus.br/arquivo/cms/processoAudienciaPublicaAdpf54/anexo/adpf54audiencia.pdf

${ }^{113}$ Ver despacho publicado em 01/09/2008, disponível na seção Acompanhamento Processual, no site do STF.
} 
manifestado na mesma audiência representando uma das entidades convidadas pelo Ministro $^{114}$.

Além desses, mais oito participantes inscreveram-se: quatro representando os amici curiae admitidos após o despacho convocatório e quatro indicados pelo Ministro relator, pelo autor da ADPF 54, pelo Advogado-Geral da União e pelo Deputado Federal Pastor Manuel Ferreira ${ }^{115}$.

Já a audiência que tratou da saúde pública e do Sistema Único de Saúde, por não ter sido realizada para auxiliar o julgamento de uma ação específica, adotou o primeiro modelo apresentado, realizando um convite amplo à sociedade: os interessados em participar deveriam fazer a solicitação por e-mail, indicando os pontos que pretendiam defender. Além desses, algumas entidades foram convidadas pelo Presidente do STF para se manifestar, devendo indicar seus representantes.

Passado o período para inscrição, foi publicado novo despacho ${ }^{116}$ do Ministro Gilmar Mendes, então Presidente da Corte, informando quem seriam os habilitados a falar. No documento é destacado o grande número de requerimentos recebidos e a intenção de garantir a participação dos diversos segmentos da sociedade, não ficando claro, porém, se todos os inscritos foram habilitados. Poucos dias após a publicação desse despacho, outro foi divulgado ${ }^{117}$, incluindo um participante que não constava na lista anterior.

A audiência referente às cotas no ensino superior, por sua vez, embora tenha sido convocada para auxiliar no julgamento de dois casos específicos - a ADPF 186 e o Recurso Extraordinário 597.285/RS, ambos de relatoria do Ministro Ricardo Lewandowski - seguiu a linha da audiência anterior, sobre a saúde, abrindo as inscrições a todos os interessados, que deveriam manifestar-se por e-mail, indicando os pontos que pretendiam defender.

\footnotetext{
${ }^{114}$ Pelo Acompanhamento Processual, disponível no site do STF, vê-se que o despacho que autorizou essas participações foi emitido em 26/08/08, no mesmo dia da primeira sessão da audiência realizada sobre o tema, já tendo o referido participante falado em nome do amicus curiae Associação Nacional PróVida e Pró-Família.

${ }^{115}$ Dados obtidos na seção Acompanhamento Processual, no site do STF.

${ }^{116}$ Despacho de habilitação de especialistas, disponível em http://www.stf.jus.br/arquivo/cms/processoAudienciaPublicaSaude/anexo/Despacho_de_habilitacaox.pdf. ${ }^{117}$ Despacho de habilitação de especialistas, disponível em http://www.stf.jus.br/arquivo/cms/processoAudienciaPublicaSaude/anexo/Despacho_de_habilitacao2.pdf.
} 
Logo após a publicação do despacho convocatório, que não destacou nenhum especialista em particular para participar, o relator enviou convites à algumas entidades $^{118}$ a fim de que, se interessadas, indicassem um representante para se apresentar em um dos dias designados para a realização da audiência pública.

Encerrado o prazo para inscrição, foi publicado despacho com a relação dos habilitados a participar da audiência. Nesse despacho o Ministro relator informou também que foram recebidas 252 inscrições de interessados, tendo sido necessário selecionar, dentre esses, um número reduzido de expositores. Para essa seleção, afirma que os critérios utilizados visaram a "garantir, ao máximo, (i) a participação dos diversos segmentos da sociedade, bem como (ii) a mais ampla variação de abordagens sobre a temática das políticas de ação afirmativa de acesso ao ensino superior".

No total, 40 participantes foram habilitados a falar, mas durante a realização das audiências o relator autorizou a participação de algumas pessoas que não constavam na lista de habilitados, não sendo possível, porém, saber se chegaram a inscrever-se para participar.

Assim, ao final da primeira sessão da audiência, o Ministro Lewandowski deu a palavra ao Senador Demóstenes Torres, presidente da Comissão de Constituição e Justiça do Senado e filiado ao partido Democratas (DEM), arguente da ADPF 186. Por tratar-se do único representante do Senado presente, o relator optou por não limitar sua apresentação ao tempo previsto aos demais participantes ${ }^{119}$, dando-lhe o tempo que julgasse necessário para se manifestar.

Além dessa manifestação, ao final da última sessão da referida audiência, o Ministro relator deu a palavra a dois estudantes de Universidades públicas ${ }^{120}$ que também não figuravam entre os habilitados para participar, para que manifestassem opiniões quanto às políticas de ação afirmativa de acesso ao ensino superior.

Também optou pelo primeiro modelo de escolha de participantes a audiência designada para debater a "Lei Seca", que disponibilizou em seu despacho convocatório um

\footnotetext{
${ }^{118}$ Informação obtida na seção Acompanhamento Processual, no site do STF.

${ }^{119}$ Questões como o tempo de exposição e outras envolvendo a organização das audiências serão tratadas posteriormente.

${ }^{120}$ Foram eles David Curianuzio, da UFRGS, e Moacir Carlos da Silva, da UERJ.
} 
endereço eletrônico para que todos os interessados pudessem se inscrever. Porém, tal despacho trouxe ainda um rol de oito $\operatorname{convidados}^{121}$ escolhidos pelo relator da ADI 4.103, Ministro Luiz Fux, que poderiam indicar expositores.

Ao final do prazo de inscrição, foi divulgada uma lista com 22 participantes habilitados, mas até a data da audiência essa lista foi alterada algumas vezes ${ }^{122}$, contando com 30 expositores no último rol divulgado ${ }^{123}$.

$\mathrm{Na}$ audiência que debateu a proibição do uso de produtos com amianto em sua composição, o Ministro Marco Aurélio, relator da ADI 3.937, decidiu inicialmente pelo modelo que prevê a escolha de participantes por indicação da requerente e demais interessados na ação.

Com a convocação, a Associação Brasileira das Indústrias e Distribuidores de Produtos de Fibrocimento (ABIFIBRO), a Associação Brasileira dos Expostos ao Amianto (ABREA) e o Instituto Brasileiro de Crisotila (IBC), todos amici curiae na ação, bem como a Confederação Nacional dos Trabalhadores da Indústria (CNTI), requerente, peticionaram ao STF indicando, cada um, um rol de especialistas que deveriam se apresentar.

Em resposta a esses e outros pedidos diversos, o relator decidiu por disponibilizar um endereço eletrônico para que aqueles legitimados a indicar participantes, ou seja, as entidades já admitidas no processo, enviassem os nomes dos especialistas. Na mesma decisão ${ }^{124}$, indicou ele mesmo outras entidades a quem deveriam ser expedidos convites para participar. Assim, após a publicação no site do Tribunal de três diferentes cronogramas até a realização do evento, manifestaram-se nas sessões da audiência 35 expositores.

\footnotetext{
${ }^{121}$ Ver despacho disponível em http://www.stf.jus.br/arquivo/cms/processoAudienciaPublicaAdin4103/anexo/Referente_ao_Despacho_d e_Convocacao_de_Audiencia_Publica.pdf

${ }^{122}$ Ver na seção Acompanhamento Processual, no site do STF, os despachos de 01/03/2012, 11/04/2012 e 03/05/2012.

${ }^{123}$ Disponível em http://www.stf.jus.br/portal/autenticacao/ sob o número 1963658.

${ }^{124}$ Ver despacho de 23/05/2012, disponível na seção Acompanhamento Processual, no site do STF.
} 


\subsubsection{Participações indeferidas}

Como se pode constatar, nem sempre é possível saber quando uma indicação ou inscrição de especialista é negada, sobretudo se é destacado um endereço eletrônico para que se envie tal pedido, como tem ocorrido nas audiências mais recentes. Quando é possível ter acesso a tal dado ${ }^{125}$, contudo, vê-se que as justificativas dadas pelos Ministros para o indeferimento do pedido podem ser resumidas em quatro tipos: intempestividade do requerimento, falta de representatividade do postulante, interesse já representado por outro expositor e ainda casos em que o indeferimento não foi justificado, baseando-se apenas na discricionariedade que o relator possui para escolher os participantes.

A partir da seção de Acompanhamento Processual do site do STF é possível identificar que o único pedido de participação indeferido pelo Ministro Carlos Ayres Britto logo na primeira audiência pública realizada pela $\operatorname{Corte}^{126}$ se deu em razão da falta de representvidade do solicitante. O pedido feito por Reginaldo Luz Ghisolfi, que alegou interesse em participar por estudar há anos o tema, foi negado nos seguintes termos: "Ainda que patente a relevância da matéria aqui veiculada, é incontroversa a falta de representatividade do postulante, razão porque indefiro o seu pedido",127.

A intempestividade, por sua vez, foi a justificativa dada nos dois únicos pedidos de participação indeferidos pela Relatora na audiência que tratou da importação de pneus usados $^{128}$. Ambos solicitavam a figuração nos autos como amici curiae, além da habilitação como expositores na audiência. Assim, tiveram o primeiro pedido atendido, embora o segundo tenha sido indeferido pela Ministra Cármen Lúcia por ser considerado intempestivo, já que ultrapassaram o prazo, determinado no próprio despacho convocatório, para indicação de especialistas por parte dos amici curiae.

\footnotetext{
${ }^{125}$ Ver seção Acompanhamento Processual, no site do STF.

126 Embora conste no site apenas esse caso, Fabrício Juliano Mendes Medeiros afirma que se não houvesse limitação nas indicações de especialistas, "centenas de expertos poderiam solicitar - como de fato solicitaram - a sua habilitação para falar na referida audiência pública”. (Op. cit., p.3). O autor dá a entender, assim, que outros pedidos de participação foram efetuados e indeferidos.

${ }^{127}$ Informação disponível na seção Acompanhamento Processual do site do STF em 05/05/06.

${ }^{128}$ Informação disponível na seção Acompanhamento Processual do site do STF em 26/06/08 e 01/07/08.
} 
Já na audiência pública referente à antecipação terapêutica do parto de fetos anencefálicos, é possível encontrar número significativamente maior de pedidos indeferidos, com as quatro justificativas já apresentadas.

A discricionariedade conferida pela legislação ao Ministro foi o argumento utilizado em resposta à petição da Confederação Nacional das Entidades de Família (CNEF), pelo Relator, Marco Aurélio, que alegou que, pela lei, fica a seu critério a aceitação ou não do órgão como participante: "Tanto é assim que o ato do relator, situado no campo da prática de ofício, não se mostra suscetível de impugnação na via recursal" ${ }^{129}$. Prosseguiu afirmando que não poderia "proceder à abertura a ponto de permitir que um número indeterminado de interessados se pronuncie", vez que outras entidades já haviam sido selecionadas para manifestarem-se pelo grupo representante da comunidade ${ }^{130}$. Assim, além da questão da discricionariedade, justificou a recusa em razão de a opinião sustentada pelo requerente já ter representante na audiência.

Justificativa semelhante foi dada ao indeferir quatro pedidos de participação feitos pela Conectas Direitos Humanos e Centro de Direitos Humanos, entendendo que "O interesse das entidades é idêntico ao de tantas outras que autuam na área de direitos humanos, não se podendo cogitar de domínio técnico suficiente a assentar-se a possibilidade de suplementação de elementos além daqueles buscados com as audiências já designadas" ${ }^{\prime 131}$.

Apesar dessa resposta, solicitação de participação na audiência feita posteriormente, pelas mesmas entidades, mas dessa vez já indicando o especialista expositor, foi atendida, tendo o relator alegado que "A representatividade das entidades sugere a audição da cidadã credenciada, visando a colher elementos para o julgamento seguro da matéria"132. O Ministro então concluiu a decisão afirmando que "se não houver

\footnotetext{
${ }^{129}$ Informação disponível na seção Acompanhamento Processual do site do STF em 01/09/08.

${ }^{130}$ As apresentações foram divididas em três grupos que se apresentaram em quatro dias. Essa questão será tratada posteriormente, na análise da organização das audiências públicas.

${ }^{131}$ Informação disponível na seção Acompanhamento Processual do site do STF em 01/09/08.

${ }^{132}$ Informação disponível na seção Acompanhamento Processual do site do STF em 04/09/08.
} 
possibilidade de ouvir a representante na audiência de 4 próximo, será designada outra data" 133 .

Se para o caso anterior abriu-se a possibilidade de alterar a data de apresentação do especialista na hipótese daquela designada ser inviável, o mesmo não ocorreu com o pedido de outras entidades.

A Federação Espírita Brasileira teve sua petição indeferida em 11 de setembro de 2008 com fundamento na intempestividade, já que os segmentos religiosos já haviam sido ouvidos no primeiro dia ${ }^{134}$. No mesmo dia a Federação Nacional dos Enfermeiros teve seu pedido rejeitado em razão da proximidade do encerramento da audiência pública, cuja útima sessão estava marcada para o dia 16 do mesmo mês. Pelo mesmo motivo, a Pastoral da Criança, o Movimento em Defesa da Vida de Porto Alegre e a Associação Nacional Mulheres pela Vida não puderam participar, acrescentando o Relator a ideia de que o interesse dessas entidades já seria representado por outros expositores ${ }^{135}$.

Além desses casos, nessa audiência viu-se negado também o pedido de inscrição de Inri Cristo e Paulo Restiffe Neto, além do primeiro rol de especialistas indicados pelo Procurador-Geral da República ${ }^{136}$.

O primeiro teve petição indeferida em razão de sua falta de representatividade, afirmando o relator que "O interesse do requerente é idêntico ao de tantos outros, não se podendo cogitar de domínio técnico, científico ou religioso suficiente a assentar-se a possibilidade de suplementação de elementos além daqueles buscados com a audiência designada"137. Já Paulo Restiffe Neto, que requereu a participação na qualidade de curador do nascituro, teve seu pedido negado com base no fundamento de que, no caso, não cabia admissão de curador de nascituro ${ }^{138}$.

Além desses casos, os dados disponíveis mostram apenas um outro pedido de participação indeferido nas audiências até aqui realizadas, que se deu na audiência

\footnotetext{
${ }^{133}$ Refere-se ao dia 4 de setembro de 2008, terceiro dia da audiência sobre antecipação terapêutica do parto de fetos anencefálicos.

${ }^{134}$ Informação disponível na seção Acompanhamento Processual do site do STF em 12/09/08.

${ }^{135}$ Informação disponível na seção Acompanhamento Processual do site do STF em 16/09/08.

${ }^{136}$ A questão já foi exposta no item anterior, ao tratar dos participantes da referida audiência.

${ }^{137}$ Informação disponível na seção Acompanhamento Processual do site do STF em 04/09/08.

${ }^{138}$ Informação disponível na seção Acompanhamento Processual do site do STF em 01/09/08.
} 
referente ao sistema de cotas nas Universidade públicas. Nesse caso, não constam na seção de acompanhamento processual os mais de 250 pedidos de participação que o Ministro Ricardo Lewandowski, responsável por sua convocação, afirma ter recebido dentro do prazo de inscrição, já que os mesmos deveriam ser enviados a um endereço eletrônico divulgado no despacho convocatório.

Consta, porém, uma petição enviada pelo Estado do Rio de Janeiro no início de fevereiro de 2010 visando à inclusão do Procurador do Estado Henrique Pereira de Sousa Werneck Martins na lista de participantes. A solicitação foi indeferida em razão de sua intempestividade, uma vez que o prazo para inscrição já havia sido ultrapassado, o que, para o relator, prejudicaria a "devida paridade de participação daqueles que defendem a constitucionalidade e a inconstitucionalidade das políticas de ação afirmativa de reserva de vagas no ensino superior" ${ }^{2139}$.

\subsubsection{Perfil dos expositores}

Para que se possa determinar qual a contribuição da audiência pública na decisão do Tribunal, é fundamental que se observe o perfil daqueles que foram selecionados para participar, já que são eles que fornecerão as informações e esclarecimentos aos Ministros.

Nesse sentido, diferenciam-se, entre os expositores, aqueles que podem ser classificados como técnicos, por serem especialistas em um determinado tema que deve ser conhecido pelos membros do STF para a tomada da decisão, e as demais pessoas, que não são especialistas na matéria a ser julgada pelo Tribunal, mas são ouvidas por integrarem a sociedade civil, representando, portanto, os diferentes pontos de vista nela presentes.

Ainda dentro dessa divisão, questão relevante é a presença de juristas como expositores. Se por um lado eles podem ser classificados como técnicos, por serem especialistas em Direito, sua participação é pouco útil do ponto de vista do aumento da legitimidade técnica, já que os membros do STF são, de acordo com a lei, pessoas com notório saber

\footnotetext{
${ }^{139}$ Informação disponível na seção Acompanhamento Processual do site do STF em 02/03/10.
} 
jurídico ${ }^{140}$, não precisando portanto de esclarecimentos em matéria que já são especialistas. Assim, a participação dos juristas apenas seria justificável não compondo o grupo de técnicos, mas como representantes dos diversos pontos de vista da sociedade civil.

$\mathrm{Na}$ audiência que tratou das pesquisas com células-tronco embrionárias, dos 22 expositores, todos eram profissionais das áreas médicas e biológicas, com exceção da antropóloga Débora Diniz e dos juristas Oscar Vilhena e Paulo Silveira Martins Leão Júnior. Esses últimos, mesmo tendo sido habilitados, não puderam participar da exposição de depoimentos uma vez que sua formação e atuação restringiam-se à área jurídica, tendo entendido o relator que ouvi-los nesse momento seria uma forma de antecipar a fase de sustentação oral ${ }^{141}$.

Já na audiência referente à ADPF 101, encontravam-se entre os onze expositores profissionais de diversas áreas: ambientalistas, especialistas em gestão de resíduos, representante das indústrias de pneus remoldados e membros do Ministério de Relações Exteriores, Ministério da Saúde e Ministério do Desenvolvimento, Indústria e Comércio Exterior. Diferentemente da audiência anterior, essa admitiu a participação de profissional da área jurídica ${ }^{142}$, desde que se tratasse de especialista no tema debatido ${ }^{143}$.

\footnotetext{
${ }^{140}$ Ver art. 101 da Constituição Federal.

141 "Tanto assim que alguns advogados e juristas se habilitaram para falar na sessão de hoje e tivemos de demovê-los desse propósito, porque a exposição propriamente jurídica não é para hoje." Disse o Ministro relator Carlos Ayres Britto, conforme Transcrição da Audiência Pública, p. 99 - AP 16, p. 18, reproduzida por Rafael Scavone Bellem de Lima, A Audiência Pública realizada na ADI 3510-0: A organização e o aproveitamento da primeira audiência pública da história do Supremo Tribunal Federal, São Paulo: monografia (Escola de Formação da Sociedade Brasileira de Direito Público), 2008, p.22.

${ }^{142}$ Foi ouvido o advogado Emanuel Roberto de Nora Serra, especialista na área ambiental.

${ }^{143} \mathrm{Na}$ página dedicada à audiência pública referente à ADPF 101, no site do STF, encontram-se dúvidas enviadas por e-mail por interessados e respondidas pelo gabinete da Ministra relatora. Na indagação feita pelo Escritório Dra. Patrícia Hernandez, a Ministra mostra seu entendimento no que diz respeito à participação de profissionais da área jurídica:

“3. 'ESPECIALISTAS seriam: técnicos, advogados? Qual qualificação do ESPECIALISTA?'

O sentido da palavra especialista é a que consta da Lei n. 9.882/99 (art. $6^{\circ}, \S 1^{\circ}$ ), sendo óbvio que audiência pública não é espaço nem promove o momento para sustentação oral jurídica: é a oportunidade para especialistas da área defenderem as teses de que cuida a ação.

4. 'A ANIP foi admitida no feito na qualidade de amicus curiae. Haverá necessidade de se inscrever para participar da audiência pública. Poderá ser feita a inscrição de mais de uma pessoa representando a ANIP (Presidente da ANIP, advogados constituídos, técnicos)?'

Sim, há necessidade de se inscrever o amicus curiae, que poderá, se assim entender conveniente, indicar um especialista. Como antes ponderado, a menos que se cuide de advogado especialista (não no processo, mas na matéria cuidada), o que se requer é a indicação de especialista no tema debatido e não na defesa da tese judicialmente discutida."
} 
No evento posterior, que debateu a antecipação terapêutica do parto de fetos anencefálicos, foram 27 especialistas que se apresentaram. Dentre eles, encontravam-se profissionais da área da saúde, cientistas, membros de organizações defensoras dos Direitos Humanos e Direitos da Mulher, bem como representantes de algumas religiões difundidas pelo país. Além deles, foram ouvidos, no mesmo período reservado à exposição de Lia Zanotta Machado, um casal que interrompeu a gestação em razão do diagnóstico de anencefalia do feto.

Vale mencionar que alguns desses especialistas usaram o espaço que tinham para expor argumentos de terceiros, lendo e exibindo depoimentos de mulheres que passaram pela gravidez de fetos anencefálicos ${ }^{144}$. Essa prática pode, de certo modo, ser considerada como uma maneira de levar ao conhecimento do Supremo Tribunal Federal depoimentos de indivíduos que não seriam habilitados a participar da audiência pública, caso fosse seguida a disciplina legal pertinente a esses instituto, que faculta ao relator a convocação de "pessoas com experiência e autoridade na matéria".

A audiência que discutiu os problemas enfrentados pelo Judiciário com relação ao Sistema Único de Saúde contou com um grande número de participantes: foram ouvidos 49 expositores, sobretudo das áreas médica e farmacêutica, além de representantes dos entes públicos nas diversas áreas afetadas pelo problema. É interessante notar ainda o grande número de profissionais do Direito, como procuradores, juízes e advogados ${ }^{145}$. A questão chama a atenção pelo fato de que, em audiências anteriores, aqueles cuja formação e atuação se restringiam à área jurídica não puderam participar.

$\mathrm{Na}$ audiência que tratou da reserva de vagas no ensino público superior, entre os 43 participantes ouvidos, encontravam-se sobretudo representantes das Universidades e de movimentos sociais, mas também o arguente da ADPF 186 e representante do

\footnotetext{
${ }^{144}$ Maria José Rosado, representante da ONG Católicas pelo Direito de Decidir, leu carta escrita por mulher que gerou filho anencefálico por não ter conseguido na Justiça o direito de interromper a gestação. Lia Zanotta Machado, representando a Rede Nacional Feminista de Saúde, Direitos Sexuais e Direitos Reprodutivos, leu trechos de depoimentos e depois exibiu um vídeo com os relatos de mulheres que viveram o diagnóstico de gerar um feto anencefálico. Já Elizabeth Kipman Cerqueira apresentou vídeo com depoimentos de duas mulheres que também receberam esse diagnóstico.

${ }^{145}$ Foram ouvidos representantes do Conselho Nacional de Procuradores-Gerais de Justiça do Ministério Público dos Estados e da União - CNPG, do Fórum Nacional dos Procuradores-Gerais das Capitais Brasileiras, da Associação dos Magistrados Brasileiros - AMB, além de defensores públicos, juízes e procuradores estaduais.
} 
recorrente do Recurso Extraordinário 597.285/RS, além de alguns profissionais de áreas jurídicas $^{146}$.

Como já informado, durante a realização da audiência dois estudantes de Universidades públicas foram convidados a se manifestarem, aumentando, assim como nos depoimentos de gestantes ouvidos na audiência que auxiliou o julgamento da ADPF 54, o acesso da sociedade à Corte, mas não contribuindo para o esclarecimento de questões técnicas.

Quando se discutiu a chamada "Lei Seca", por sua vez, foram ouvidos 29 participantes entre representantes de ONGs e outros profissionais que promovem a segurança no trânsito, representantes de associações de bares e outros estabelecimentos que comercializam bebida alcóolica, profissionais da saúde e alguns juristas.

Assim como na audiência que tratou da interrupção da gestação de feto anencéfalo, houve participante habilitado que optou por ceder parte do seu tempo de exposição para ouvir depoimento pessoal de vítima de acidente de trânsito ocasionado pela embriaguez do condutor e até mesmo ONG que trouxe como único representante parente de vítima para contar sua experiência.

Interessante notar que, apesar de permitir a participação de profissionais do Direito, o Ministro Relator, Luiz Fux, reclamou, antes do início da segunda sessão da audiência, das questões jurídicas levantadas por alguns expositores no dia anterior, já que elas, segundo o Ministro, deveriam ser apreciadas apenas pelos membros do Tribunal. Já durante a segunda sessão, o Relator interrompeu alguns participantes pedindo que se ativessem a questões técnicas, chegando até mesmo a dispensar um deles durante sua exposição por ter insistido em tratar de questões jurídicas ${ }^{147}$.

Já na audiência convocada em razão do julgamento referente à proibição do uso de produtos com amianto, a maior parte dos 35 expositores era formada por cientistas,

\footnotetext{
${ }^{146}$ Foram ouvidos representantes da AJUFE - Associação dos Juízes Federais, bem como da ANAPE Associação Nacional dos Procuradores de Estado, além do Juiz Federal Carlos Alberto da Costa Dias. Outros expositores, embora de formação jurídica, participaram representando movimentos sociais, instituições de ensino e o próprio recorrente do Recurso Extraordinário 597.285/RS.

${ }_{147}$ Tal situação ocorreu com Norton Luiz Lenhart, que representou o Sindicato de Hotelaria e Gastronomia de Porto Alegre, o Sindicato de Bares e Restaurantes do Espírito Santo e o Sindicato de Bares e Restaurantes de São Paulo.
} 
químicos, biólogos e médicos, sendo muitos deles estrangeiros. Além desses, participaram especialistas em meio ambiente, integrantes de diversos Ministérios Federais, bem como representantes de empresas e dos trabalhadores, não havendo a presença de juristas.

\subsubsection{Organização dos expositores}

A forma como as exposições são organizadas, bem como o tempo que cada expositor terá direito e a dinâmica adotada nas apresentações também não são determinadas pela lei, ficando a critério do Ministro que presidir a audiência. É inegável que assim como a forma de escolha dos participantes e o perfil desses, o procedimento adotado na audiência é fundamental para determinar seu resultado, já que ele determinará como serão conduzidas as exposições, se haverá ou não debates entre os presentes, etc.

Pela análise das audiências públicas realizadas pelo STF até o presente momento, podese notar certas formas de organização: enquanto em algumas houve a divisão dos participantes em dois blocos antagônicos, em outras adotou-se a classificação com base no segmento da sociedade que representariam, havendo também a opção por uma organização relacionada a questão que cada expositor responderia e aquelas audiências em que não se adotou nenhum critério específico de divisão.

O tempo dedicado a cada expositor e a abertura dada para questionamentos também variou conforme as audiências públicas. Assim, em alguns casos, ao final de cada exposição, o Ministro que presidia a audiência abriu espaço para perguntas; em outros, esse espaço não era dado. Além desse fator, a presença e interação dos Ministros no evento também altera, de certa forma, a dinâmica e a efetividade da audiência.

A primeira audiência pública executada pelo STF ocorreu em um único dia, 24 de abril de 2007, pelo período da manhã e da tarde. Os expositores foram definidos em dois blocos antagônicos: os favoráveis às pesquisas com células-tronco embrionárias na forma prevista na lei, e os contrários. 
Em virtude da inexistência, à época, de regulamentação das audiências por parte do Regimento Interno do STF, o Ministro Relator optou por aplicar nesse caso as normas do Regimento Interno da Câmara dos Deputados, que disciplinam as audiências públicas naquele órgão ${ }^{148}$. Na prática, porém, o que se viu foi a inobservância dessas regras, substituídas por normas criadas pelo próprio relator no dia da audiência.

Assim, o tempo de exposição não foi de 20 minutos por convidado, prorrogáveis a juízo do Relator, como previsto ${ }^{149}$. O Ministro Carlos Ayres Britto definiu que os dois períodos de realização da audiência seriam divididos igualmente entre os dois grupos expositores, que poderiam ajustar livremente entre seus membros o tempo que lhes coubesse.

Para definir a ordem de apresentação foi realizado um sorteio, o qual determinou que o bloco favorável às pesquisas iniciaria a exposição, que prosseguiria com a alternância dos grupos.

Essa alternância na apresentação, entretanto, não visava a favorecer a contraposição de ideias, como esclareceu o relator durante a audiência ${ }^{150}$. O objetivo, na verdade, foi favorecer a igualdade de participação e evitar que os blocos ficassem concentrados no período da manhã e no período da tarde, permitindo assim que os dois grupos expusessem em ambos os períodos.

Dos onze membros do Supremo Tribunal Federal, apenas quatro compareceram à primeira audiência pública ali realizada: o Relator, Ministro Carlos Ayres Britto, a presidente do STF à época da audiência, Ellen Gracie, além dos Ministros Gilmar Mendes e Joaquim Barbosa. Além desses, informou o relator ${ }^{151}$ que o Ministro Ricardo Lewandowski acompanhava a sessão da cidade de São Paulo, o que era possível em virtude da transmissão ao vivo do evento tanto pela TV Justiça, quanto pela Rádio Justiça.

\footnotetext{
148 Arts. 255 a 258 do Regimento Interno da Câmara dos Deputados.

${ }^{149}$ Art. 256, $\S 2^{\circ}$ do Regimento Interno da Câmara dos Deputados.

150 "A primeira parte expositiva transcorreu em clima de respeito, de reverência. Não houve contraposição de quem quer que fosse. O certo é isso. Aqui não haverá contraditório, debate, confronto." Assim orientou o Ministro Relator Carlos Ayres Britto, conforme Transcrição da Audiência Pública, p.55, reproduzida em Rafael Scavone Bellem de Lima, Op. cit., p.30.

${ }^{151}$ Transcrição da Audiência Pública, p.137, reproduzida em Rafael Scavone Bellem de Lima, Op. cit., p.38.
} 
Após as apresentações, abriu-se espaço para a formulação de perguntas pelos Ministros, para esclarecimento de possíveis dúvidas. Três questões foram elaboradas pelo Ministro Carlos Ayres Britto e outras duas foram enviadas à sessão pelo Ministro Ricardo Lewandowski e pelo gabinete do Ministro Eros Grau, todas dirigidas aos dois blocos de participantes $^{152}$.

Não havendo regulamentação prévia a esse respeito, estabeleceu-se que cada grupo de expositores teria dez minutos para responder a todas as questões elaboradas, não sendo admitidas réplicas, tréplicas ou qualquer confrontação ${ }^{153}$.

Na segunda audiência pública realizada, referente a ADPF 101, a Ministra responsável optou por elaborar ela mesma as regras procedimentais que conduziriam o evento. Para tanto, definiu no próprio despacho convocatório a estrutura das exposições, reservando para todas um único dia, 27 de junho de 2008.

Assim, como já visto, determinou-se a divisão dos inscritos em dois grupos: um favorável e outro contrário à importação de pneus usados. Desses, apenas quatro representantes de cada grupo seriam habilitados. Não havendo consenso entre os interessados, seria realizado um sorteio para determinar os quatro expositores de cada lado. Esse procedimento foi observado durante a audiência, mas foram onze, e não oito, os escolhidos para falar, ficando o bloco contrário à importação com um representante a mais.

Além disso, o despacho definiu também o tempo de apresentação de cada um. Cada expositor sorteado teria no máximo vinte minutos de apresentação, mesmo tempo cedido ao arguente, que abriria a audiência, e ao Procurador-Geral da República, que também teria direito a manifestar-se.

No dia da audiência, tendo em vista o número de participantes maior do que o previsto pelas regras elaboradas, alguns expositores dividiram seu espaço com outros do mesmo grupo, tendo portanto, cada um, o tempo máximo de dez minutos para apresentação ${ }^{154}$.

\footnotetext{
${ }^{152}$ Optou o relator por dirigi-las a ambos os grupos, ainda que assim não tenham determinado os Ministros que as formularam.

${ }^{153}$ Transcrição da Audiência Pública, p.217, reproduzida em Rafael Scavone Bellem de Lima, Op. cit., p.72.
} 
Tendo sido convidados todos os membros do Supremo Tribunal Federal para integrarem a mesa e participarem da audiência pública, estiveram presentes apenas os Ministros Gilmar Mendes, Carlos Ayres Britto e Ricardo Lewandowski, além da Relatora, a Ministra Cármen Lúcia.

Ao contrário do que ocorreu na primeira audiência realizada pelo STF, nesta não houve qualquer interação entre os Ministros e os participantes, uma vez que nenhum questionamento foi feito acerca da matéria debatida.

Já a audiência que discutiu a possibilidade de antecipar o parto em caso de gestação de feto anencéfalo foi dividida em quatro dias entre o fim de agosto e o início de setembro de $2008^{155}$, com o fim de ouvir representantes dos grupos religiosos, médicos e da sociedade civil.

Embora o despacho convocatório e o cronograma não mencionassem expressamente uma divisão em grupos como forma de organizar as exposições, é possível identificar tal divisão pelos despachos ${ }^{156}$ emitidos pelo Ministro Relator bem como pelas declarações por ele dadas nas sessões da audiência ${ }^{157}$.

Desta vez, optou o Relator por conceder o tempo de quinze minutos para que cada participante pudesse concluir sua exposição. Além disso, após cada audição abriu-se

\footnotetext{
${ }^{154}$ Pelo bloco contrário à importação, o Ministro Carlos Minc dividiu seu espaço com Welber de Oliveira Barral, e Carlos Márcio Bicalho Cozendey partilhou seu tempo com Zuleica Nycs. Pelo bloco favorável, Ricardo Alípio da Costa dividiu seu espaço com Paulo Janissek.

${ }^{155}$ Inicialmente, no despacho convocatório, as datas previstas eram 26, 27 e 28 de agosto de 2008, sendo o primeiro dia dedicado aos grupos religiosos, o segundo às entidades sociais e o último aos representantes da área médica. Com o aumento do número de participantes, as audiências foram designadas para 26 e 28 de agosto e 04 e 16 de setembro de 2008 , ficando o primeiro dia reservado às entidades religiosas, o segundo à ala médica e os dois últimos às entidades sociais.

${ }^{156}$ Como já visto, o relator indeferiu o pedido de participação de alguns especialistas devido à impossibilidade de manifestarem-se no dia reservado ao grupo da sociedade que representavam.

${ }^{157}$ Ao iniciar o segundo dia de audiências, o Ministro Marco Aurélio disse "Ouvimos, na primeira Sessão, segmentos mais calcados na área da religião. Hoje, temos a audição de entidades do mundo científico que se pronunciarão, mediante professores, representantes devidamente credenciados, sobre a matéria" e no mesmo dia, para explicar a oitiva da expositora Lenise Aparecida Martins Garcia, afirmou "Um esclarecimento a todos. Tínhamos realmente programado as sessões e as audições por bloco considerados os blocos religioso, comunitário e científico -, mas houve necessidade de cancelarmos a sessão que seria realizada ontem pela manhã, ante a convocação matutina para começarmos a discutir a questão alusiva às terras indígenas. Daí termos invertido um pouco os trabalhos e termos quebrado a ordem inicialmente planejada". Ver notas taquigráficas da audiência do dia 28/08/08, diponíveis em http://www.stf.jus.br/arquivo/cms/processoAudienciaPublicaAcaoAfirmativa/anexo/Notas_Taquigraficas _Audiencia_Publica.pdf
} 
espaço para questionamentos a serem feitos pela requerente, pelo Ministério Público, pela Advocacia Geral da União e pelos próprios Ministros.

Assim, quase todas as exposições foram seguidas de perguntas, principalmente da CNTS, requerente, mas também do Ministério Público, de representantes da AGU e dos Ministros Marco Aurélio e Gilmar Mendes. Além desses, o Ministro relator autorizou ainda uma pergunta feita diretamente da platéia ${ }^{158}$.

Nessa etapa, salientou o relator que não se tratava "propriamente, de debates. Não é uma fase propícia a polemizar-se o que veiculado, mas voltada a esclarecimento de alguma dúvida que tenha permanecido quanto ao que versado" ${ }^{\prime 159}$, chegando inclusive a interromper o advogado da requerente para pedir que este evitasse colocações que pudessem sugerir réplica e tréplica.

No último dia, após a oitivas de todos os expositores, iniciou-se a "fase de considerações finais", que, segundo o relator, não se confundiria com as alegações finais. Foram ouvidos representantes da requerente, da AGU e do Ministério Público.

Ao longo dos quatro dias de audiência, apenas o Relator presenciou todas as exposições, tendo ainda o então presidente do STF, Gilmar Mendes, e o Ministro Menezes Direito acompanhado parte das apresentações.

A audiência seguinte, que discutiu a saúde pública, apesar de ter sido convocada já sob a vigência da Emenda n. 29, também precisou de regras formuladas especialmente para sua realização. Desta forma, o então presidente do STF, Ministro Gilmar Mendes, determinou em despacho de habilitação de especialistas que cada um disporia de quinze minutos para se apresentar.

O despacho também definiu as datas das audiências. Antes previstas ${ }^{160}$ para três dias em abril de 2009, as apresentações foram remarcadas para 26, 28 e 29 de abril e 4, 6 e 7 de maio, restando, deste modo, um dia dedicado para cada uma das seis questões propostas pelo Ministro.

\footnotetext{
${ }^{158}$ Ver notas taquigráficas da audiência do dia 16/09/08.

${ }^{159}$ Ver notas taquigráficas da audiência do dia 26/08/09.

${ }^{160}$ Assim estabelecia o despacho convocatório da audiência pública, cujo link já foi disponibilizado.
} 
Assim, no primeiro dia discutiu-se a responsabilidade dos entes da federação em matéria de direito à saúde, e nos outros cinco dias, respectivamente, a obrigação do Estado de fornecer prestação de saúde prescrita por médico não pertencente ao quadro do SUS ou sem que o pedido tenha sido feito previamente à Administração Pública, a obrigação do Estado de custear prestações de saúde não abrangidas pelas políticas públicas existentes, a obrigação do Estado de disponibilizar medicamentos ou tratamentos experimentais não registrados na ANVISA ou não aconselhados pelos Protocolos Clínicos do SUS, a obrigação do Estado de fornecer medicamento não licitado e não previsto nas listas do SUS e, por fim, as fraudes ao Sistema Único de Saúde.

Não está claro, pelas informações disponíveis, se cada especialista escolheu a questão que iria discutir ou se essa divisão foi feita pelo Ministro que presidiu a audiência. Observa-se, entretanto, que a distribuição dos participantes pelos dias marcados foi feita exclusivamente em virtude da questão a ser debatida, não sendo possível identificar qualquer subdivisão ou polarização deles em cada questão.

Estipulou-se o tempo de 15 minutos para cada exposição, não tendo ocorrido questionamentos ou debates após as manifestações. Embora tenha sido convocada para subsidiar o julgamento de diversas ações, apenas o então Presidente do STF, Gilmar Mendes, esteve presente todos os dias, tendo comparecido em algumas sessões os Ministros Cezar Peluso e Menezes Direito.

Para a audiência que discutiu a questão da reserva de vagas no ensino público superior, foram destinados os dias 3, 4 e 5 de março de 2010.

Reservou-se o primeiro dia às instituições estatais responsáveis pela regulação e organização das políticas nacionais de educação e de combate à discriminação racial, bem como para a instituição responsável por mensurar os resultados dessas políticas públicas, além das partes nos processos relacionados à audiência: o arguido e arguente da ADPF 186 e o requerido e requerente do Recurso Extraordinário 597.285/RS.

Destinou-se o segundo dia e a primeira sessão do terceiro dia para a oitiva de outros especialistas, entre eles antropólogos e professores, defenderem suas teses favoráveis e contrárias à constitucionalidade da política de reserva de vagas. A sessão vespertina do 
último dia foi dedicada à apresentação de representantes de diversas Universidades públicas, além da Associação dos Juízes Federais.

Embora a divisão dos participantes pelos dias de audiência tenha sido feita de acordo com a especialidade de cada um, e não em blocos antagônicos, opondo favoráveis e contrários à medida discutida, percebe-se que o posicionamento de cada expositor foi considerado no momento da habilitação, uma vez que, como já visto, ao indeferir um pedido de participação, o Ministro Relator argumentou, entre outros motivos, que tal participante não seria aceito em respeito à "devida paridade de participação daqueles que defendem a constitucionalidade e a inconstitucionalidade das políticas de ação afirmativa de reserva de vagas no ensino superior"161.

O posicionamento dos participantes também foi levado em consideração para definir a ordem em que esses falariam. Ficou determinado, em cronograma divulgado no site do STF, que no segundo dia de audiência, bem como na primeira sessão do terceiro dia, aqueles que se posicionavam a favor da tese de constitucionalidade iniciariam o contraditório, que seria encerrado pelos defensores da tese da inconstitucionalidade das políticas de reserva de vaga.

Importante destacar que, dias antes da realização da audiência, o partido Democratas (DEM) entrou no STF com um pedido de reconsideração do despacho de habilitação dos participantes, argumentando que, dentre os 40 habilitados, 28 eram favoráveis às cotas, o que tiraria a isonomia entre os dois pontos de vista.

O Ministro Relator, Ricardo Lewandowski, indeferiu o pedido alegando que organizou a audiência pública "para ouvir as diferentes perspectivas conformadoras da sociedade brasileira sobre a utilização do critério étnico-racial na seleção de candidatos para o ingresso no ensino superior"162. Declarou ainda: "Não há nenhum lado que está sendo tomado pelo Supremo Tribunal Federal ou por aquele que organiza as audiências, mas

\footnotetext{
${ }^{161}$ Informação disponível na seção Acompanhamento Processual do site do STF em 02/03/10.

${ }^{162}$ Informação disponível na seção Acompanhamento Processual do site do STF em 02/03/10.
} 
nós procuramos organizar a programação de maneira a permitir o maior equilíbrio e a maior isonomia e igualdade entre as partes" ${ }^{\prime 63}$.

No próprio despacho convocatório previu-se o tempo de quinze minutos para a intervenção de cada participante. Durante as exposições, os membros do Tribunal ficaram livres para fazer perguntas aos participantes, que chegaram a ser questionados em algumas oportunidades pelo Ministro Ricardo Lewandowski, bem como pela Ministra Cármen Lúcia, no último dia de audiência.

Tendo sido convidados todos os membros do Supremo Tribunal Federal, estiveram presentes, além do Relator - único que compareceu a todas as sessões - apenas os Ministros Gilmar Mendes, Joaquim Barbosa e Cármen Lúcia.

Para a audiência pública que tratou da constitucionalidade da chamada "Lei Seca", foram reservados os dias 7 e 14 de maio de 2012.

Diferentemente das outras audiências, em que foi possível identificar um critério de divisão dos expositores, nessa parece não se ter optado por um modelo de organização. Apesar de contar com membros de diversos segmentos da sociedade, participantes favoráveis e contrários à constitucionalidade da lei e ter estipulado questões que deveriam ser respondidas durante as exposições, o dia e a ordem de manifestação de cada participante não foram determinados conforme nenhum critério identificável.

A cada expositor foi reservado o prazo de 15 minutos para se apresentar, não tendo havido previsão de espaço para perguntas ou debates, que não ocorreram. Estiveram presentes, além do relator da ADI, Luiz Fux, os Ministros Rosa Weber e Carlos Ayres Britto - esse apenas abriu a primeira sessão, tendo que se ausentar em razão de compromisso do Conselho Nacional de Justiça.

No mesmo ano, em 24 e 31 de agosto, ocorreu a audiência pública que tratou da proibição do uso de amianto. Assim como na audiência anterior, não é possível identificar nessa um critério de organização dos participantes com relação ao dia ou a ordem de exposição.

\footnotetext{
${ }^{163}$ Disponível em http://veja.abril.com.br/blog/reinaldo/geral/o-debate-nas-cotas-do-supremo-e-aestranha-matematica/.
} 
Estabeleceu-se o prazo de 20 minutos para cada manifestante, embora a Confederação Nacional dos Trabalhadores na Indústria (CNTI), tenha requerido, ao indicar especialistas, tempo de 40 minutos para as exposições ${ }^{164}$.

$\mathrm{Na}$ abertura da primeira sessão, o Ministro Relator destacou a existência de dois segmentos - favoráveis e contrários ao uso do amianto -, e a divisão dos expositores visou a obedecer esse critério, procurando intercalar representantes dos dois grupos, embora nem sempre isso tenha ocorrido. Assim, ainda que não tenha havido menção expressa, pode-se dizer que nessa audiência, assim como nas referentes a ADI 3.510 e ADPF 101, optou-se pela organização em blocos antagônicos.

Reservaram-se as últimas sessões do segundo dia de audiência aos expositores estrangeiros, o que provavelmente se deu para o melhor aproveitamento do serviço de tradução simultânea.

Ao final de cada exposição abriu-se espaço para questionamentos, que foram feitos a quase todos os expositores pelo representante da Procuradoria-Geral da República, havendo também algumas perguntas feitas pelos Ministros Marco Aurélio e Ricardo Lewandowski. Esteve presente o Ministro Marco Aurélio em todos os dias, tendo comparecido em algumas sessões apenas os Ministros Ricardo Lewandowski e Rosa Weber.

\subsection{Análise crítica das audiências públicas}

Considerando-se que as audiências públicas jurisdicionais têm como objetivo imediato fornecer informações complementares que possam auxiliar os Ministros em suas decisões, pode-se concluir que qualquer que seja o método adotado para a seleção e organização de participantes, dentre os já empregados nas audiências, o uso desse instrumento contribuirá com tal finalidade, em maior ou menor grau.

\footnotetext{
${ }^{164}$ Ver pedido em petição de 15/06/12, disponível em http://redir.stf.jus.br/estfvisualizadorpub/jsp/consultarprocessoeletronico/ConsultarProcessoEletronico.jsf ?seqobjetoincidente $=2544561$.
} 
Entretanto, este trabalho visa a analisar um dos objetivos mediatos das audiências, frequentemente apontado pela doutrina e pelos próprios membros da Corte: o acréscimo de legitimidade democrática às decisões proferidas pelos Ministros do STF. É esse, portanto, o tema desta breve análise crítica.

Para que a função de aprimorar a legitimidade democrática das decisões do Supremo seja alcançada pelas audiências, é necessário, primeiramente, que seja garantida ampla participação neste procedimento, para que as diversas correntes de posicionamento possam ser ouvidas.

Conforme visto ao longo deste capítulo, dentre as três formas empregadas para a seleção dos expositores, aquela que abre inscrições para quaisquer interessados habilitarem-se a participar parece ser a que melhor cumpre o papel de expandir a representação da sociedade. Assim também entende Anna Candida da Cunha Ferraz, para quem "A escolha dos participantes, para ser representativa, deve ser efetivamente aberta à opinião pública por meio de chamamento popular de entidades via publicidade no Diário Oficial, Internet, etc., conforme estabelece o RISTF"165.

Inegavelmente, essa forma de escolha de participantes permite uma maior e melhor representação das diversas correntes de opinião presentes na sociedade do que se a indicação de expositores ficasse restrita às partes. Como qualquer interessado pode se inscrever para manifestar suas ideias perante o Tribunal, há uma maior probabilidade de que os argumentos expostos nas audiências não se limitem aos defendidos pelas partes no processo.

Deixar a indicação dos participantes unicamente nas mãos do Ministro que presidir a audiência ou das partes e amici curiae da ação tende a limitar as exposições a argumentos já conhecidos por eles, pouco acrescentando à formulação de opinião daqueles que irão julgar, além de restringir a participação popular a posições que já seriam ouvidas pelo Supremo. Pouco contribui, portanto, para a prometida pluralização e abertura da jurisdição constitucional concentrada.

\footnotetext{
${ }^{165}$ Anna Candida da Cunha Ferraz, "A Projeção da Democracia Participativa na Jurisdição Constitucional no Brasil: As Audiências Públicas e sua Adoção no Modelo Concentrado de Constitucionalidade”, p.118.
} 
Sobre a indicação de participantes feita exclusivamente pelos amici curiae admitidos na ação, como ocorreu na audência da ADI 101, cabe um breve comentário.

Há quem entenda a audiência pública como decorrente do instituto do amicus curiae ${ }^{166}$, arena, portanto, para uma melhor exposição dos argumentos dos amici curiae. Nesse sentido, Damares Medina conceitua a audiência como um "procedimento por intermédio do qual desbordou a atuação do amicus curiae"167, um "auditório público que vem se afirmando como uma forma complementar e talvez o ambiente propício para que o amicus possa atuar em vista de preservar-se o equilíbrio processual e a igualdade entre as partes" ${ }^{\prime 68}$.

Em razão desse entendimento, a autora exalta a forma de escolha de expositores utilizada na audiência pública relativa a ADPF 101, em que eles foram indicados pelos amici curiae já admitidos na ação, elogiando o "caráter inovador, ao conduzir os amici curiae a um ambiente igualitário de participação, preservados os interesses antagonizados na ação" ${ }^{\text {169 }}$.

Este trabalho, porém, defende que a audiência pública é instituto independente e não decorrente do amicus curiae, como será melhor estudado posteriormente ${ }^{170}$, razão pela qual entendemos que restringir a indicação de participantes aos amici curiae já admitidos limita o grande potencial que as audiências públicas possuem de pluralizar a jurisdição constitucional.

É esse também o entendimento expresso no trabalho coordenado por Vanice Regina Lírio do Valle, que, ao analisar a audiência vinculada à ADPF 101, em que os participantes foram indicados pelos amici curiae admitidos na ação, constatou: "o que se configurou foi uma espécie de 'réplica' dos 'amigos da corte' aos argumentos centrais suscitados na arguição, justamente porque a maioria destes atuava na defesa de

\footnotetext{
${ }^{166}$ Essa questão será melhor tratada ao analisarmos o instituto do Amicus curiae.

${ }^{167}$ Damares Medina, Op. cit., p.81.

${ }^{168}$ Ibidem, p.82.

${ }^{169}$ Ibidem, p.83.

${ }^{170}$ Ver as diferenças entre amicus curiae e audiência pública, tratadas na p.87 e seguintes.
} 
seus próprios interesses, posto que atingidos diretamente pelos efeitos da futura decisão" ${ }^{171}$.

Contudo, garantir uma forma mais democrática de habilitação de interessados em participar não é suficiente. Se muitos forem os inscritos, como de fato ocorreu quando se optou pelas inscrições abertas a todos, haverá a necessidade de selecionar os participantes. Centralizar nas mãos do Ministro Relator o poder de decidir quem, dentre aqueles que se habilitaram, efetivamente se manifestará, sem que haja qualquer critério pré-estabelecido para tanto, pode comprometer esse processo de aumento de representatividade.

Anna Candida da Cunha Ferraz chama atenção para esse risco nos seguintes termos:

"Cabe ainda anotar que fica à discrição do Relator escolher as entidades representativas da sociedade que podem participar da audiência. Embora a regra regulamentar exija respeito à igualdade e à proporcionalidade, essa escolha pode se mostrar até tendenciosa, se não houver critérios rigorosos a respeito dela, já que a decisão do Relator é irrecorrível." ${ }^{\text {172 }}$

Além disso, é importante que o maior número possível de pessoas possa participar. É claro que, tendo em vista os muitos inscritos, dificilmente será possível que todos manifestem-se, mas, havendo a possibilidade de destinar alguns dias a mais às audiências para que se garanta uma maior participação popular, é preferível que assim ocorra $^{173}$.

O perfil dos participantes também tem grande influência no andamento da audiência e, consequentemente, em seu rendimento. Se o texto legal fala em "pessoas com experiência e autoridade na matéria" ${ }^{174}$, percebe-se que muitas vezes a expressão foi

\footnotetext{
${ }^{171}$ Vanice Regina Lírio do Valle [coord.], Audiências públicas e ativismo: Diálogo social no STF, Belo Horizonte: Fórum, 2012, p.74.

${ }^{172}$ Anna Candida da Cunha Ferraz, "A Projeção da Democracia Participativa na Jurisdição Constitucional no Brasil: As Audiências Públicas e sua Adoção no Modelo Concentrado de Constitucionalidade”, p.118.

173 Como foi visto, o número de expositores selecionados e os dias dedicados às audiências sofreram grande variação de um procedimento para outro. Na audiência relativa à importação de pneus usados, por exemplo, apenas 11 especialistas foram ouvidos, embora alguns outros tenham sido indicados pelas partes, destinando-se um único dia para o evento. Já na audiência que tratou das questões envolvendo o Sistema Único de saúde, ouviram-se 49 especialistas em 6 dias de evento.

${ }^{174}$ Arts. $9^{\circ}, \S 1^{\circ}$ e $20, \S 1^{\circ}$ da Lei $9.868 / 99$ e Art. $6^{\circ}, \S 1^{\circ}$ da Lei $9.882 / 99$.
} 
interpretada em sentido amplo, englobando não só especialistas nos assuntos, mas também entidades e organizações sociais, além de autoridades públicas e políticas ${ }^{175}$.

Nesses casos, optou-se por ouvir pessoas que, embora não fossem autoridade no assunto, representavam o posicionamento dos diversos segmentos da sociedade ${ }^{176}$. Percebe-se, assim, que para suprir a falta de legimitidade técnica do Supremo Tribunal Federal em alguns dos casos de sua competência, deve-se preferir a participação de técnicos, autoridades na matéria em debate. Ao se optar, todavia, por participantes que não são especialistas no tema discutido, privilegia-se o papel das audiências públicas de acrescer legitimidade democrática ao julgamento.

Como foi visto, enquanto em algumas audiências a participação de juristas e a discussão de matéria jurídica foram expressamente proibidas, sob os argumentos de que não deveria ocorrer uma antecipação da fase de sustentação oral e de que o Direito é matéria de conhecimento dos membros do STF - não sendo necessário, portanto, que os expositores se prolonguem no assunto -, em parte das audiências considerável parcela dos participantes era composta por profissionais do Direito.

Sob o mesmo fundamento - evitar que a audiência pública seja uma antecipação da fase de sustentação oral - é questionável também a presença das partes da ação a ser julgada pelo STF como participantes da audiência ${ }^{177}$. Dar a palavra a tais pessoas, que poderão ser ouvidas em outra etapa do processo, não acresce, portanto, a tão comemorada legitimidade democrática nem mesmo acresce legitimidade técnica à decisão do Tribunal $^{178}$.

\footnotetext{
${ }^{175}$ Anna Candida da Cunha Ferraz, "A Projeção da Democracia Participativa na Jurisdição Constitucional no Brasil: As Audiências Públicas e sua Adoção no Modelo Concentrado de Constitucionalidade”, p. 108. ${ }^{176}$ A participação deu-se tanto de forma direta como indireta. De forma direta pode-se entender a participação de estudantes de Universidades Públicas, na audiência que tratou da reserva de vagas nessas unidades de ensino, ou mesmo a oitiva de representantes de diversas religiões seguidas no Brasil, nas audiências referentes às pesquisas com células-tronco humanas e à antecipação do parto de fetos anencefálicos. A participação de forma indireta ocorreu, por exemplo, na audiência que tratou da interrupção da gravidez de feto anencefálico, quando alguns dos especialistas selecionados decidiram utilizar o espaço que tinham para expor lendo depoimentos de mulheres que tiveram uma gravidez com tal complicação.

${ }^{177}$ Como já visto, na audiência pública referente à reserva de vagas nas universidades públicas foram ouvidas, juntamente com os demais participantes habilitados, as partes na Arguição de Descumprimento de Preceito Fundamental 186 e no Recurso Extraordinário 597.285/RS.

${ }^{178}$ No mesmo sentido, é irrelevante para tais funções a oitiva do Procurador-Geral da República e do Advogado-Geral da União, já que eles poderão ser ouvidos em outra etapa do processo.
} 
Contra a participação desses, Anna Candida da Cunha Ferraz manifesta-se:

"De certo modo, a participação de autoridades públicas (os requeridos, Presidente da República e o Presidente do Congresso Nacional) e de advogados e juristas tende a desviar o foco de atenção das audiências públicas, centrado na elucidação de questões técnicas, de fato e científicas por especialistas, técnicos e cientistas, como previsto na Lei 9.868/99" "179.

Não se defende aqui a exclusão da participação de todo e qualquer jurista e autoridade dos eventos, mas que eles se concentrem em trazer informações sobre o tema debatido, e não em defender determinada tese jurídica.

Não basta, porém, que tudo isso seja garantido se a forma como os expositores forem organizados for capaz de restringir sua participação. Assim, a divisão em blocos antagônicos que visam à defesa de uma única posição sobre o caso a ser julgado é questionável, uma vez que reduz, de forma simplista, uma vasta gama de posicionamentos possíveis.

Deve-se lembrar que a função das exposições é fornecer informações que possam esclarecer os Ministros na tomada de decisão - e não defender a constitucionalidade ou não de determinada lei ou ato - o que pode ser comprometido se empregada tal forma de organização dos participantes.

Essa crítica é corroborada em trabalho coordenado por Vanice Regina Lírio do Valle: “a lógica binária está a sugerir uma tese central, que se repute certa ou errada e, portanto, uma convocação para que os participantes se posicionem num ou noutro extremo" ${ }^{\text {"180 }}$.

Além de não proporcionar um significativo aumento da legitimidade democrática, a organização em grupos antagônicos também compromete o acréscimo de legitimidade técnica às decisões do STF, já que as informações fornecidas pelos especialistas também ficam limitadas apenas a argumentos favoráveis ou contrários à constitucionalidade discutida, sem que as demais questões importantes à compreensão do tema sejam debatidas.

\footnotetext{
${ }^{179}$ Anna Candida da Cunha Ferraz, “A Projeção da Democracia Participativa na Jurisdição Constitucional no Brasil: As Audiências Públicas e sua Adoção no Modelo Concentrado de Constitucionalidade”, p.101. ${ }^{180}$ Vanice Regina Lírio do Valle (coord.), Op. cit., p.116.
} 
Nesse sentido, Rafael Scavone Bellem de Lima, ao comentar a realização da primeira audiência pública realizada pelo STF, argumenta:

"Parece-me possível, diante dessa organização, que se evite, por meio da divisão dos temas das apresentações, por exemplo, a exposição de posicionamentos técnicos inconvenientes à defesa da posição representada pelo bloco. É perfeitamente possível que existam posicionamentos dessa natureza, já que os especialistas podem ter uma posição comum a respeito da decisão final do caso, divergindo, no entanto, com relação aos fundamentos dessa resposta.

O agrupamento dos especialistas em blocos de opiniões contrárias tende, na minha opinião, a estimular a exposição de argumentos técnicos que sustentem uma alternativa de decisão em detrimento do esclarecimento das diversas questões técnicas envolvidas em um caso, que dependendo da forma com que venham a ser articuladas na argumentação dos Ministros, podem justificar diferentes decisões."181

Por sua vez, a divisão dos expositores conforme a questão que devem esclarecer, embora mostre-se eficaz para garantir a diversidade social entre os participantes, limita os argumentos por eles apresentados às questões pré-estabelecidas no momento da convocação da audiência. Assim, o especialista ficará restrito ao questionamento feito pelo STF, não se manifestando sobre informações importantes que eventualmente tenha a prestar sobre as outras perguntas, ou mesmo sobre outro ponto não tratado no despacho convocatório, mas importante para a compreensão do tema.

Diante da análise feita neste capítulo, percebe-se que, dentre os modelos utilizados nas audiências até então realizadas, a forma mais proveitosa de dividir os especialistas, a fim de não comprometer sua exposição e permitindo que sejam levantadas quaisquer questões que considerem relevantes para o esclarecimento do tema, parece ser a organização dos participantes conforme o segmento da sociedade que representam ${ }^{182}$.

\footnotetext{
${ }^{181}$ Rafael Scavone Bellem de Lima, Op. cit., p.27.

182 "Parece, portanto, mais adequada a orientação que já se identificou na audiência pública da saúde e naquela vinculada à $\mathrm{ADPF} \mathrm{n}^{\circ} 186$, que aponta temas em relações aos quais pretenda a Corte se ver esclarecida - sem uma pretensão de que visão binária da controvérsia" (Vanice Regina Lírio do Valle (coord.), Op. cit., p.117). Vale ressaltar, porém, a diferença no procedimento das duas audiências citadas:
} 
Outra questão destacada por participantes e Ministros durante as audiências foi a proporcionalidade entre representantes dos diversos posicionamentos, que embora não seja garantida legalmente, foi muitas vezes defendida como fundamental para o bom prosseguimento da audiência.

Sob a ótica do aumento da legitimidade democrática, a manutenção ou não da proporção entre as diversas correntes é pouco relevante desde que se garanta a representação de todas elas. Todavia, se o objetivo da audiência não for apenas apontar os diversos posicionamentos existentes, mas também refletir a representação desses interesses na sociedade, a igualdade de defensores de posturas distintas certamente impedirá que esse fim seja alcançado.

Tanto para que a função de acréscimo de legitimidade técnica seja observada, quanto para que haja uma maior qualidade na participação da sociedade, parece necessário, além das garantias de ampla participação aqui já tratadas, que se permita o livre debate de ideias, para que de fato possam ser esclarecidas as eventuais dúvidas dos membros do Tribunal.

Mostra-se importante, assim, que se permita o debate ${ }^{183}$ entre os defensores de posicionamentos diferentes ${ }^{184}$, já que, a simples apresentação de argumentos, sem que as ideias contrárias possam ser rebatidas, poderá confundir os Ministros, que ficarão sobrecarregados de informações, sem quaisquer esclarecimentos. A ideia aqui não é garantir com que os Ministros cheguem a um consenso ou a "resposta certa" - o que provavelmente não existe nas questões debatidas - mas que cada um possa ter todas as informações que precisa para constituir sua opinião.

Para isso, seria apropriado que se destinasse uma parte das audiências para que tanto os Ministros como os próprios participantes pudessem formular questões aos especialistas. A atual regulamentação existente não prevê tal fase na audiência, deixando a critério do Relator permitir ou não que sejam feitas perguntas aos expositores. Nas poucas

enquanto aquela que tratou da saúde definiu questões a serem respondidas pelos expositores, a audiência vinculada à ADPF 186 dividiu os expositores quanto ao segmento social que representavam, deixando-os livres para o esclarecimento do tema.

${ }^{183}$ Desde que corretamente conduzido, a fim de que se evite sua desqualificação e a rivalidade entre os participantes, o que dificilmente contribuirá para qualquer esclarecimento.

${ }_{184}$ Como já foi dito, o debate foi terminantemente proibido na audiência que tratou das pesquisas com células-tronco embrionárias, pois o relator entendeu que tal procedimento criaria uma contraposição de ideias, não sendo esse o objetivo do evento. 
audiências em que esse procedimento foi permitido, apenas os Ministros, a Procuradoria-Geral da República e a Advocacia Geral da União fizeram intervenções ${ }^{185}$.

Ademais, ainda que se verifique todo o procedimento acima descrito como mais benéfico para que haja um aumento da legitimidade democrática do STF, isso de nada valerá se os membros do Tribunal, verdadeiros destinatários de todas as informações ali apresentadas, não participarem do evento.

Embora o Regimento Interno do STF determine que as audiências públicas sejam televisionadas e transmitidas via rádio, o que permitiria que os Ministros as acompanhassem ainda que à distância, isso não é suficiente para que haja amplo aproveitamento de tal evento. A presença, e, mais do que isso, a participação dos membros do Tribunal, possibilitará que as audiências constituam de fato um diálogo entre esse órgão do Judiciário e a população, e não apenas uma simples exposição de ideias por parte desta.

Como pode-se constatar a partir das informações apresentadas neste capítulo, a presença dos Ministros nos eventos foi ínfima. Na maior parte das sessões compareceu apenas o Ministro que presidia a audiência, havendo vez ou outra a presença do Presidente do Tribunal ou de algum outro membro, que raramente permaneciam durante todo o evento alegando outros compromissos relacionados ao cargo.

Em que pesem as inúmeras atribuições e a apertada agenda do $\mathrm{STF}^{186}$, parece imprescindível a participação dos Ministros em um evento organizado justamente para colher informações que subsidiem seus votos. Nesse sentido, Oscar Vilhena Vieira defende a presença obrigatória dos Ministros nas audiências públicas como uma dentre diversas medidas que poderiam ser implementadas para melhorar a qualidade do processo deliberativo do $\mathrm{STF}^{187}$.

Por fim, resta lembrar que não há um dever de vinculação ou subordinação da decisão do Tribunal com aquilo que foi apresentado na audiência, mas “certamente há o dever

\footnotetext{
${ }^{185}$ Exceção feita à audiência relativa a interrupção da gestação de fetos anencefálicos, em que, como visto, os participantes também fizeram perguntas a seus pares.

${ }^{186}$ Sobre esse tema, ver Oscar Vilhena Vieira, "Supremocracia".

${ }^{187}$ Ibidem, p.459.
} 
de considerar essas contribuições, para incorporá-las ou descartá-las" "188, já que, do contrário, "a audiência pública se afigura como evento simbólico, e não como uma atividade efetivamente destinada à prática dialógica e ao robustecimento da deliberação pública" 189 .

\subsection{Conclusão}

Pelo que foi aqui analisado, viu-se que existem meios de conduzir a audiência pública que permitem uma maior abertura à sociedade civil e, possivelmente, um acréscimo de legitimidade democrática às decisões do Supremo Tribunal Federal.

Assim, conclui-se que há participação democrática em maior grau e de melhor qualidade quando as audiências são abertas para que qualquer interessado possa se inscrever para expor; permite-se o maior número possível de expositores, levando-se em consideração a escassez de tempo e a apertada agenda do STF; prioriza-se a oitiva de especialistas e membros da sociedade civil, em detrimento de juristas focados em defender determinada tese jurídica, e de partes e terceiros que podem ser ouvidos em momentos diversos; permite-se a livre manifestação do expositor, não restringindo sua fala a questões pré-determinadas nem forçando-o a posicionar-se pela procedência ou improcedência da ação; promove-se o debate, permitindo-se o esclarecimento de dúvidas e a contraposição de ideias; há efetiva participação dos Ministros durante o procedimento, etc.

Por outro lado, viu-se que a regulamentação da matéria é mínima, não garantindo a lei essa abertura democrática, mas deixando-a a critério do Ministro Relator. Como visto, ele tem discricionariedade para convocar ou não a audiência - ainda que previstos todos os requisitos legais -, optar pela forma de indicação dos participantes, selecionar quantos e quais serão os expositores habilitados, definir qual tempo será destinado à audiência e a cada exposição, abrir ou não espaço para debates e questionamentos, etc.

\footnotetext{
${ }^{188}$ Vanice Regina Lírio do Valle (coord.), Op. cit., p.120.

${ }^{189}$ Ibidem, p. 121.
} 
O alto grau de discricionariedade depositado nas mãos do Ministro responsável por presidi-la, porém, faz com que as audiências não sigam o mesmo padrão, não tenham um perfil único. Ao contrário, como se viu, seu perfil - e, consequentemente, sua capacidade de acrescer legitimidade democrática à decisão do STF - variará de acordo com a forma que o Relator organizá-la ${ }^{190}$.

Pelos dispositivos legais atuais e pela forma que as audiências públicas têm sido conduzidas, seu objetivo parece ser o de acrescer legitimidade técnica às decisões, e não o de permitir uma maior participação popular e, consequentemente, acrescer legitimidade democrática à Corte.

Para que as audiências públicas possibilitem o grau de pluralização da jurisdição constitucional que a doutrina tanto festeja, parece primordial que haja uma verdadeira regulamentação da matéria, de modo a orientar o uso de tal instrumento para os fins pretendidos. Essa opinião é compartilhada por Ana Cândida da Cunha Ferraz, que conclui, após analisar o tema:

"Parece evidente, todavia, que, para que não se desvirtuem de seus fins, as audiências públicas devem se submeter a normas procedimentais rigorosas que atendam seus objetivos finais, especialmente no que respeita à efetiva ressonância social da matéria em questão e à representatividade dos convocados, observados os princípios da igualdade e da publicidade na convocação e na participação dos especialistas e entidades que devam prestar esclarecimentos sobre questões técnicas." ${ }^{191}$

Se há na doutrina quem se preocupe com uma regulamentação excessiva da matéria, que acabe por engessar a realização das audiências ${ }^{192}$, este trabalho defende que, na atual situação, o perigo é justamente o oposto: a frouxidão na regulamentação desse instituto pode desvirtuá-lo de seus fins, transformando-o em um evento meramente simbólico,

\footnotetext{
${ }^{190}$ Nesse sentido, o estudo coordenado por Vanice Regina Lírio do Valle conclui: "o que a análise de cada qual das audiências públicas evidencia é uma diversidade de práticas e orientação de trabalhos, decorrente do papel predominante - e incensurável - do Ministro Relator, que parece incompatível com um ideal de diálogo, quando menos daquele orientado à deliberação". (Op. cit., p.126)

${ }^{191}$ Anna Candida da Cunha Ferraz, "A projeção da democracia participativa na jurisdição constitucional no Brasil: as audiências públicas e sua adoção no modelo concentrado de constitucionalidade", p.117.

${ }^{192}$ Diogo Rais, Op. cit., p.130.
} 
que nada acrescente ao processo deliberativo dos membros do STF, mas que o legitime perante a sociedade ${ }^{193}$.

Vê-se, portanto, que, enquanto o tema não receber um tratamento normativo mais detalhado, a contribuição que a audiência pública poderá oferecer, com relação ao acréscimo de legitimidade democrática às decisões do STF, será aquele que o Ministro que a presidir quiser, de acordo com a forma de organização e condução da audiência que optar por utilizar.

193 O estudo coordenado por Vanice Regina Lírio do Valle aponta para esse risco ao dissertar sobre audiências que não cumprem seu papel de pluralizar o debate: "Isso transforma, todavia, o instituto, não em canal para o desenvolvimento efetivo do diálogo social - em toda a sua riqueza -, mas numa oportunidade para a criação de uma espécie de representação pacificadora de uma prática que pode estar (ainda que inconscientemente) orientada à chancela de uma visão do problema já predefinida; e o que é pior, predefinida nem mesmo pela Corte como um todo, mas exclusivamente pelo Relator, que na sua condução de presidente da diligência, tem ainda suas deciões blindadas pelo signo da irrecorribilidade, como já referido, excluindo portanto a cunhagem do diálogo social do âmbito de decisão do colegiado como um todo." (Op. cit., p.119). 


\section{Amicus curiae}

\subsection{Histórico normativo na jurisdição constitucional concentrada}

O instituto do amicus curiae (do latim, "amigo da corte"), cuja origem não é consenso entre os doutrinadores ${ }^{194}$, popularizou-se em razão de seu uso no direito norteamericano e é amplamente aplicado no direito brasileiro, embora nossa legislação raramente se utilize dessa denominação para identificar o instrumento aqui estudado, como ressalta Cássio Scarpinella Bueno ${ }^{195}$.

O mesmo ocorre na jurisdição constitucional, que passou a prever tal instituto a partir da Lei 9.868 de 1999, e posteriormente na Lei 9.882, do mesmo ano, sem fazer qualquer referência à expressão amicus curiae. Em verdade, antes mesmo das referidas leis o instrumento já era utilizado em sede de controle concentrado de constitucionalidade ${ }^{196}$, mas foi a partir de então que passou a integrar o ordenamento jurídico brasileiro.

Assim, o artigo $7^{\circ}$ da Lei 9.868/99, que regulamenta os processos da ação direta de inconstitucionalidade e da ação declaratória de constitucionalidade, determina:

“Art. 7ํㅗ Não se admitirá intervenção de terceiros no processo de ação direta de inconstitucionalidade.

$\S 1^{\underline{0}}$ Os demais titulares referidos no art. $2^{\underline{0}}$ poderão manifestar-se, por escrito, sobre o objeto da ação e pedir a juntada de documentos reputados úteis para o exame da matéria, no prazo das informações, bem como apresentar memoriais. (VETADO)

$\S 2^{\mathrm{o}} \mathrm{O}$ relator, considerando a relevância da matéria e a representatividade dos postulantes, poderá, por despacho irrecorrível,

\footnotetext{
${ }^{194}$ Há aqueles que entendem que suas referências mais remotas encontram-se no direito inglês, enquanto para outros, tem origem no direito romano. Ver Thais Catib De Laurentiis, A caracterização do amicus curiae à luz do Supremo Tribunal Federal, São Paulo: monografia (Escola de Formação da Sociedade Brasileira de Direito Público), 2007, pp.11-12.

195 “Não há, no direito brasileiro, nenhuma referência legislativa expressa à figura do amicus curiae. Não pelo menos com o emprego desse nome. O único ato normativo que dele se ocupa com essa denominação é o art. 23, $\$ 1^{\circ}$ da Resolução n. 390, de 17 de setembro de 2004, do Conselho da Justiça Federal, ao qual já fizemos menção anteriormente. Mesmo assim, são diversas as fontes que descrevem situações jurídicas que, para nós ao menos, só fazem sentido se forem identificadas como casos de amicus curiae." (Cássio Scarpinella Bueno, Amicus curiae no processo civil brasileiro: um terceiro enigmático, São Paulo: Saraiva, 2006, p.126)

${ }^{196}$ A participação do amicus curiae foi admitida, por exemplo, nas ADIs 575 e 784-5, ambas anteriores às leis de 1999.
} 
admitir, observado o prazo fixado no parágrafo anterior, a manifestação de outros órgãos ou entidades." (Grifamos)

O artigo supracitado refere-se à ação direta de inconstitucionalidade e à ação direta de inconstitucionalidade por omissão, em razão do artigo 12-E da mesma lei, que prevê a aplicação das mesmas regras, no que couber, para as duas ações. O prazo a que faz referência está previsto no artigo $6^{\circ}$, parágrafo único, e é de 30 dias ${ }^{197}$ contado do recebimento do pedido.

Quanto à ação declaratória de constitucionalidade, tratada pela mesma lei, reservaram a ela as disposições do art.18, que teve seus parágrafos vetados:

“Art. 18. Não se admitirá intervenção de terceiros no processo de ação declaratória de constitucionalidade.

$\S 1^{\underline{0}}$ Os demais titulares referidos no art. 103 da Constituição Federal poderão manifestar-se, por escrito, sobre o objeto da ação declaratória de constitucionalidade no prazo de trinta dias a contar da publicação do edital a que se refere o artigo anterior, podendo apresentar memoriais ou pedir a juntada de documentos reputados úteis para o exame da matéria.(VETADO)

$\S 2^{\underline{0}} \mathrm{O}$ relator, considerando a relevância da matéria e a representatividade dos postulantes, poderá, por despacho irrecorrível, admitir, observado o prazo estabelecido no parágrafo anterior, a manifestação de outros órgãos ou entidades.(VETADO)"

A impressão que se tem, em razão dos vetos dos dois artigos e da inadmissão de intervenção de terceiros em ambas as ações é de que o uso do amicus curiae estaria comprometido. Entretanto, para a correta compreensão do tema, faz-se necessária uma breve explicação sobre a intervenção de terceiros, além da análise das razões dos vetos desses artigos.

Para explicar a relação entre a intervenção de terceiros e a jurisdição constitucional concentrada, recorrer-se-á aos ensinamentos de Cássio Scarpinella Bueno em obra que,

\footnotetext{
197 “Art. $6^{\circ}$ O relator pedirá informações aos órgãos ou às autoridades das quais emanou a lei ou o ato normativo impugnado.

Parágrafo único. As informações serão prestadas no prazo de trinta dias contado do recebimento do pedido."
} 
embora voltada ao amicus curiae no Processo Civil brasileiro, traz importantes observações sobre o uso desse instrumento no Processo Constitucional.

Assim, para o autor, a lei não autoriza a intervenção de terceiros nessas ações pois "o Supremo Tribunal Federal, no exercício do controle concentrado de constitucionalidade, não 'julga' nenhum interesse ou direito subjetivado, isto é, concretizado em uma específica relação jurídica que dá ensejo, por definição, ao nascimento de pretensões concretas" ${ }^{\prime 198}$. Essa particularidade dessas ações estaria perdida se fosse admitida a intervenção de terceiros tal como conhecida no processo civil.

O amicus curiae, diferentemente da intervenção de terceiros, é instituto que, "pelas suas próprias origens, apresenta-se livre das amarras do 'processo civil tradicional', no sentido de ser individualístico e privatístico, adjetivos que não podem ser empregados para a descrição do processo das ações diretas de inconstitucionalidade e das ações declaratórias de constitucionalidade" 199 .

Constata-se, então, que a proibição expressa na lei é quanto às formas de intervenção de terceiros conhecidas do "processo civil tradicional", e não quanto ao amicus curiae, um terceiro especial, de natureza excepcional ${ }^{200}$, admitido a critério do relator e se cumpridos os requisitos que serão analisados a seguir. Conclui o autor: "'Terceiro' ele é, mas não aquele terceiro que o Supremo Tribunal Federal sempre negou - e continua negando - pudesse - ou possa - intervir nas ações voltadas ao controle concentrado de constitucionalidade" 201 .

Resolvida a primeira questão - quanto a inadmissão da intervenção de terceiros prevista nos artigos da Lei 9.868/99 - resta agora analisar as razões dos vetos aos parágrafos desses mesmos artigos.

A redação original do $\S 1^{\circ}$ do artigo $7^{\circ}$, referente à ação direta de inconstitucionalidade e ação direta de inconstitucionalidade por omissão, dizia:

\footnotetext{
${ }^{198}$ Cássio Scarpinella Bueno, Op. cit., p.135.

${ }^{199}$ Ibidem, p.177.

${ }^{200}$ É assim que, após analisar os diversos tratamentos dados ao amicus curiae, Ana Letícia Queiroga de Mattos define sua natureza jurídica. (Op.cit., p.176.)

${ }^{201}$ Cássio Scarpinella Bueno, Op. cit., p.136.
} 
"§ $1^{\mathrm{o}}$ Os demais titulares referidos no art. $2^{\underline{0}}$ poderão manifestar-se, por escrito, sobre o objeto da ação e pedir a juntada de documentos reputados úteis para o exame da matéria, no prazo das informações, bem como apresentar memoriais."

Inicialmente, cabe lembrar que o artigo $2^{\circ}$, ao qual o texto faz referência, diz respeito ao rol de legitimados para propositura da ação. Trazendo o parágrafo acima transcrito a descrição da atuação do amicus curiae, a primeira impressão que se tem é a de que o veto teve por fim inadmiti-lo na ação. As razões do veto, porém, esclarecem a situação:

“A aplicação deste dispositivo poderá importar em prejuízo à celeridade processual.

A abertura pretendida pelo preceito ora vetado já é atendida pela disposição contida no $§ 2^{\circ}$ do mesmo artigo. Tendo em vista o volume de processos apreciados pelo STF, afigura-se prudente que o relator estabeleça o grau da abertura, conforme a relevância da matéria e a representatividade dos postulantes." (Grifamos)

$\mathrm{O}$ art. 18, que trata da ação declaratória de constitucionalidade, teve os seguintes parágrafos vetados:

"§ $1^{\circ}$ Os demais titulares referidos no art. 103 da Constituição Federal poderão manifestar-se, por escrito, sobre o objeto da ação declaratória de constitucionalidade no prazo de trinta dias a contar da publicação do edital a que se refere o artigo anterior, podendo apresentar memoriais ou pedir a juntada de documentos reputados úteis para o exame da matéria.

$\S 2^{\circ} \mathrm{O}$ relator, considerando a relevância da matéria e a representatividade dos postulantes, poderá, por despacho irrecorrível, admitir, observado o prazo estabelecido no parágrafo anterior, a manifestação de outros órgãos ou entidades."

Se também aqui se dá a entender que a intervenção do amicus não seria admitida, as razões do veto explicam:

“Em relação ao $\S 1^{\circ}$, a razão é a mesma do veto ao $§ 1^{\circ}$ do art. $7^{\circ}$.

$\mathrm{O}$ veto ao $\S 2^{\circ}$ constitui conseqüência do veto ao $\S 1^{\circ}$. Resta assegurada, todavia, a possibilidade de o Supremo Tribunal Federal, por meio de interpretação sistemática, admitir no processo da ação declaratória a 
Vê-se, assim, que os vetos visavam não à proibição do amicus curiae nas ações, mas sim permitir que essa possibilidade de participação fosse dada a outros que não apenas os legitimados a propor tais ações, segundo critérios a serem definidos pelo Ministro relator, conforme a relevância da matéria e a representatividade dos postulantes.

Aplica-se então tanto à ação direta de inconstitucionalidade e à ação direta de inconstitucionalidade por omissão quanto à ação declaratória de constitucionalidade, por meio de interpretação sistemática, o art. $7^{\circ}, \S 2^{\circ}$ da Lei 9.868/99.

Já a Lei 9.882/99, que dispõe sobre o processo da ação de descumprimento de preceito fundamental, prevê o amicus curiae no $\S 2^{\circ}$ do art. $6^{\circ}$ :

"Art. 6ํㅗㄹ Apreciado o pedido de liminar, o relator solicitará as informações às autoridades responsáveis pela prática do ato questionado, no prazo de dez dias.

$\S 1^{\circ}$ Se entender necessário, poderá o relator ouvir as partes nos processos que ensejaram a arguição, requisitar informações adicionais, designar perito ou comissão de peritos para que emita parecer sobre a questão, ou ainda, fixar data para declarações, em audiência pública, de pessoas com experiência e autoridade na matéria.

$\S 2^{\underline{0}}$ Poderão ser autorizadas, a critério do relator, sustentação oral e juntada de memoriais, por requerimento dos interessados no processo." (Grifamos)

O parágrafo $2^{\circ}$ do artigo supracitado é o que autoriza a utilização do amicus também na arguição de descumprimento de preceito fundamental, para grande parte da doutrina ${ }^{202}$. Há quem entenda, porém, que a admissão desse instrumento nesse tipo de ação só é

\footnotetext{
${ }^{202}$ Nesse sentido, ver Eloísa Machado de Almeida, Sociedade civil e democracia: a participação da sociedade civil como amicus curiae no Supremo Tribunal Federal, p.38; Anna Candida da Cunha Ferraz, "O amicus curiae e a democratização e a legitimação da jurisdição Constitucional concentrada" in Revista Mestrado em Direito - Direitos Humanos Fundamentais, ano 8, n. 1. Osasco: Edifieo, 2008, p.69; Thais Catib De Laurentiis, Op. cit., p.16, entre outros.
} 
possível em razão da aplicação analógica do artigo $7^{\circ}$, $\$ 2^{\circ}$ da Lei $9.868 / 99$ e da sistematização do Direito ${ }^{203}$.

Assim, conforme a corrente seguida, são essas as hipóteses para admissão de amicus curiae:

1) Para $\mathrm{ADI}, \mathrm{ADI}$ por omissão e $\mathrm{ADC}$; ou para $\mathrm{ADI}, \mathrm{ADI}$ por omissão, $\mathrm{ADC}$ e $\operatorname{ADPF}\left(\right.$ Art. $7^{\circ}, \S 2^{\circ}$ da Lei 9.868/99): O relator, considerando a relevância da matéria e a representatividade dos postulantes, poderá, por despacho irrecorrível, admitir, observado o prazo de 30 dias, a manifestação de outros órgãos ou entidades.

2) Para ADPF (Art. $6^{\circ}, \S 2^{\circ}$ da Lei 9.882/99): Poderão ser autorizadas, a critério do relator, sustentação oral e juntada de memoriais, por requerimento dos interessados no processo.

Se o tratamento normativo dispensado às audiências públicas já é mínimo, vê-se que, no caso do amicus curiae ele é ainda mais escasso. Além desses dois artigos tratando do tema, a partir das Emendas Regimentais 15, de 30 de março de $2004^{204}$, e 29, de 18 de fevereiro de $2009^{205}$, o Regimento Interno do STF passou também a referir-se ao instituto nos seguintes artigos, porém sem muita profundidade:

“Art. 13. São atribuições do Presidente:

XVIII - decidir, de forma irrecorrível, sobre a manifestação de terceiros, subscrita por procurador habilitado, em audiências públicas ou em qualquer processo em curso no âmbito da Presidência." (Grifamos)

“Art. 21. São atribuições do Relator:

XVIII - decidir, de forma irrecorrível, sobre a manifestação de terceiros, subscrita por procurador habilitado, em audiências públicas ou nos processos de sua relatoria." (Grifamos)

\footnotetext{
203 "Considerando, contudo, que a arguição de descumprimento de preceito fundamental pode assumir a feição de controle abstrato e concentrado de constitucionalidade e ter, por isso mesmo, efeitos erga omnes e efeitos vinculantes, não há como afastar a possibilidade de entidades de classe ou outros órgãos representativos de segmentos sociais pleitearem seu ingresso na qualidade de amicus curiae, fundamentando-se não só no art. $7^{\circ}, \S 2^{\circ}$, da Lei n. 9.868/99, aplicável à espécie por evidente analogia, mas, superiormente, na ordem constitucional." (Cássio Scarpinella Bueno, Op.cit., p.180.)

${ }^{204}$ Responsável pela introdução do $\$ 3^{\circ}$ do art. 131 .

${ }^{205}$ Responsável pela introdução dos incisos XVIII dos arts. 13 e 21.
} 
“Art. 131. Nos julgamentos, o Presidente do Plenário ou da Turma, feito o relatório, dará a palavra, sucessivamente, ao autor, recorrente, peticionário ou impetrante, e ao réu, recorrido ou impetrado, para sustentação oral.

$\S 3^{\circ}$ Admitida a intervenção de terceiros no processo de controle concentrado de constitucionalidade, fica-lhes facultado produzir sustentação oral, aplicando-se, quando for o caso, a regra do $\S 2^{\circ}$ do art. 132 deste Regimento." (Grifamos)

Para a compreensão dos referidos artigos deve-se lembrar da consideração feita por Cássio Scarpinella Bueno e aqui já mencionada ${ }^{206}$ de que os amici curiae são terceiros, porém de natureza diversa daqueles previstos no Código de Processo Civil e proibidos pela lei no controle concentrado de constitucionalidade.

Os incisos XVIII dos artigos 13 e 21 do Regimento Interno do Tribunal reiteram a possibilidade de participação do amicus em qualquer ação dessa forma de controle de constitucionalidade, cabendo a decisão, irrecorrível, ao Ministro Relator do processo.

Já o artigo 131, $\S 3^{\circ}$, passou a garantir a possibilidade de sustentação oral conforme as seguintes regras:

“Art. 132. Cada uma das partes falará pelo tempo máximo de quinze minutos, excetuada a ação penal originária, na qual o prazo será de uma hora, prorrogável pelo Presidente.

$\S 2^{\circ}$ Se houver litisconsortes não representados pelo mesmo advogado, o prazo, que se contará em dobro, será dividido igualmente entre os do mesmo grupo, se diversamente entre eles não se convencionar." (Grifamos)

Sendo esses os únicos artigos a tratarem do tema, as questões em que a lei é silente seguem os entendimentos firmados pela jurisprudência do STF ou, em não havendo orientação consolidada, ficam a critério do Relator.

\subsection{Definição e características}

A partir do texto legal e das considerações acima realizadas, pode-se concluir que o amicus curiae é "um terceiro que intervém no processo, do qual ele não é parte, para

${ }^{206}$ Ver pp.76-77. 
oferecer à corte sua perspectiva acerca da questão constitucional controvertida, informações técnicas acerca de questões complexas cujo domínio ultrapasse o campo legal ou, ainda, defender os interesses dos grupos por ele representados, no caso de serem, direta ou indiretamente, afetados pela decisão a ser tomada"207. Assim, demonstrada a representatividade do postulante e a relevância da matéria, o amicus poderá ser aceito.

Cabe lembrar que, embora a Lei 9.882/99, que regulamenta a arguição de descumprimento de preceito fundamental, não preveja a relevância da matéria e a representatividade do postulante como requisitos para a admissão do amicus, como já visto, há quem entenda que para essa ação aplica-se, por analogia, o art. $7^{\circ}, \S 2^{\circ}$ da Lei 9.868/99. Nesse caso, tais requisitos também devem ser observados. Esse foi o entendimento do STF, por exemplo, ao decidir o ingresso de amicus curiae nas ADPFs $46,97,33,73$, entre outras.

Outra característica desse instituto também depreendida do texto normativo é que sua admissão é de discricionariedade do Ministro Relator, sendo tal decisão irrecorrível, como determina o art. $7^{\circ}, \S 2^{\circ}$ da Lei 9.868/99. Entretanto, há divergências quanto ao tema, tendo o STF oscilado quanto à admissão de agravo regimental em caso de indeferimento do ingresso ${ }^{208}$.

\subsubsection{Formas de atuação}

Há certa flexibilização quanto às formas de atuação do amicus curiae no processo, questão de especial interesse para esse trabalho por ser fundamental para que se possa determinar o grau de participação popular na jurisdição constitucional concentrada.

Enquanto o art. $7^{\circ}, \S 2^{\circ}$ da Lei $9.868 / 99$ não especifíca a forma de manifestação, o art. $6^{\circ}$, $\S 2^{\circ}$ da Lei 9.882/99 é expresso ao admitir a sustentação oral e a juntada de memoriais como meios de participação do amicus.

\footnotetext{
${ }^{207}$ Damares Medina, Op. cit., p. 17.

${ }^{208}$ Os entendimentos dos doutrinadores e a posição atual do Tribunal serão tratadas posteriormente neste capítulo.
} 
Como já visto, porém, parte da doutrina entende que o dispositivo que prevê a intervenção do amicus curiae tanto na ADI, ADI por omissão e ADC, quanto na ADPF - por analogia - é o da Lei 9.868/99, que trata o assunto de forma genérica, sem especificar como o amicus pode atuar.

Assim, até o final de 2003 o Supremo Tribunal Federal entendia que a participação do amicus limitava-se à entrega de memoriais. Essa forma de manifestação encontrou pouca resistência por parte dos juristas, ao contrário da sustentação oral, muito criticada por comprometer a celeridade e a própria viabilização do processo.

Diante de uma crescente demanda para ampliar as formas de atuação dos amici curiae, para que o instituto de fato cumprisse com suas funções de informar os Ministros e ampliar o debate, no final de 2003, em decisões referentes à ADI 2777 e à ADI 2675, o Tribunal reconheceu, por maioria, o direito à sustentação oral para os amici curiae. Como ressalta Eloísa Machado de Almeida, essa forma de participação permite que todos os Ministros tenham contato direto com os argumentos trazidos pelo amicus, e não apenas o Relator ${ }^{209}$.

Em defesa da concessão desses poderes ao amicus, Gustavo Binenbojm escreve:

"O direito à realização da sustentação oral, assim, se apresenta como uma extensão natural, corolário lógico da admissão formal do amicus curiae como terceiro especial. Uma vez considerados presentes pela Corte os requisitos estabelecidos no art. $7^{\circ}, \S 2^{\circ}$, da Lei $\mathrm{n}^{\circ} 9.868 / 99$, isto é, a representatividade do postulante e a relevância da matéria subjacente à ação direta de inconstitucionalidade, não há como se negar ao amicus o direito à sustentação oral de suas razões, tanto como à sua expressão escrita.

Milita em favor de tal entendimento, como realçado pelo eminente Ministro Celso de Mello (em voto na ADI 2777), o sentido finalístico da norma em questão, que é o de democratizar o processo de controle concentrado de constitucionalidade, dando voz não apenas às partes formais do feito, mas

${ }^{209}$ Eloísa Machado de Almeida, Op. cit., p.51. 
também aos órgãos ou entidades representativas da sociedade civil que possam vir a sofrer a repercussão da decisão a ser proferida na ação."210

Atualmente a possibilidade de sustentação oral é pacífica, tendo o STF firmado tal entendimento incluindo em 2004 o $§ 3^{\circ}$ ao artigo 131 de seu Regimento Interno, que, como visto, prevê a sustentação oral para os amici curiae. A fim de evitar que as diversas sustentações orais comprometam a celeridade processual, porém, o Tribunal tem dividido os amici curiae em blocos antagônicos - favoráveis e contrários à ação para que, dentro de um período de tempo delimitado - normalmente uma hora -, organizem-se e façam suas exposições.

Admite-se, ainda, que o amicus apresente razões, manifestações por escrito e documentos. Há discussão, porém, quanto a sua legitimidade recursal.

Há na doutrina quem defenda essa prerrogativa processual como desdobramento natural do direito que o amicus curiae possui de apresentar seus argumentos por escrito e oralmente $^{211}$, alegando ainda que o não reconhecimento dessa prerrogativa comprometeria o potencial democratizador do instituto ${ }^{212}$.

O Supremo Tribunal Federal, entretanto, não reconhece tal legitimidade, como se vê na ementa do acórdão de 24 de fevereiro de 2011 que negou provimento a recurso de agravo interposto por amicus curiae na ADI 3934:

“CONSTITUCIONAL. AÇÃO DIRETA DE

INCONSTITUCIONALIDADE. AGRAVO REGIMENTAL EM EMBARGOS DE DECLARAÇÃO. EMBARGOS DE DECLARAÇÃO OPOSTOS POR AMICUS CURIAE. NÃO CONHECIMENTO. LEGITIMIDADE RECURSAL. INEXISTÊNCIA. I - Esta Corte pacificou sua jurisprudência no sentido de que não há legitimidade recursal das entidades que participam dos processos do controle abstrato de constitucionalidade na condição de amicus curiae, 'ainda que aportem aos

\footnotetext{
${ }^{210}$ Gustavo Binenbojm, "A dimensão do Amicus curiae no processo constitucional brasileiro: Requisitos, poderes processuais e aplicabilidade no âmbito estadual", Revista Eletrônica de Direito do Estado (Instituto de Direito Público da Bahia), n. 1, Salvador, jan./fev./mar. 2005, pp.14-15.

${ }^{211}$ Gustavo Binenbojm, Op. cit., p.17.

${ }^{212}$ Ana Letícia Queiroga de Mattos, Op. cit., p.190.
} 
autos informações relevantes ou dados técnicos' (ADI 2.591-ED/DF, Rel. Min. Eros Grau). II - Precedentes. III - Agravo Regimental Improvido.”

Gustavo Binenbojm defende ainda que podem os amici curiae requerer providências instrutórias que entenderem necessárias para o esclarecimento das questões discutidas como informações adicionais, peritos e convocação de audiência pública ${ }^{213}$ - pois se o Ministro Relator pode determinar de ofício tais providências, qualquer interessado poderá requerê-las ${ }^{214}$. A ideia é defendida também por alguns Ministros ${ }^{215}$, mas diverge do entendimento firmado pelo STF.

Se os meios que o amicus tem de participar são limitados, o mesmo não se pode dizer do conteúdo de suas manifestações. Nem a lei nem a jurisprudência trazem qualquer restrição quanto às matérias que podem ser discutidas, sendo ilimitadas, portanto, embora haja na doutrina quem entenda que o instituto visa a "aportar ao processo constitucional valiosos elementos, particularmente de natureza jurídica"216.

Em trecho de decisão monocrática da ADI 3842, por exemplo, o Ministro Gilmar Mendes ressalta a contribuição não jurídica trazida pelo amicus:

"Ao ter acesso a essa pluralidade de visões em permanente diálogo, este Supremo Tribunal Federal passa a contar com os benefícios decorrentes dos subsídios técnicos, implicações político-jurídicas e elementos de repercussão econômica que possam vir a ser apresentados pelos 'amigos da Corte'.,217

\footnotetext{
${ }^{213}$ Como visto no capítulo referente às audiências públicas, já houve pedido de audiência por parte de amicus curiae, mas independentemente de quem requeira, a convocação é de discricionariedade do Ministro Relator.

${ }^{214}$ Gustavo Binenbojm, "A dimensão do Amicus curiae no processo constitucional brasileiro: Requisitos, poderes processuais e aplicabilidade no âmbito estadual", p.19.

215 Ver voto do Ministro Celso de Mello na ADPF 187, disponível em http://www.stf.jus.br/arquivo/cms/noticiaNoticiaStf/anexo/ADPF187amicus.pdf

${ }^{216}$ Anna Candida da Cunha Ferraz, "O amicus curiae e a democratização e a legitimação da jurisdição constitucional concentrada", p.72; No mesmo sentido, ver Sociedade Brasileira de Direito Público, Judicialização da política e demandas por juridificação: o Judiciário frente aos outros poderes e frente à sociedade, Belo Horizonte: Faculdade de Filosofia e Ciências Humanas da Universidade Federal de Minas Gerais, 2011, p.185.

${ }^{217}$ No mesmo sentido, Eloísa Machado de Almeida: "Esta pode ser a melhor faceta dos amici curiae, isto é, mostrar aos Ministros uma visão não jurídica, mais concreta do problema a ser julgado e decidido." (Op. cit., p.36)
} 


\subsubsection{Finalidades}

Além desses aspectos, outro, de grande importância para a conceituação do instrumento, diz respeito às suas finalidades. Sobre o tema, Gustavo Binenbojm discorre:

“Com efeito, o propósito do art. $7^{\circ}, \S 2^{\circ}$ da Lei (9.868/99) é claramente o de pluralizar o debate constitucional, permitindo que o Tribunal venha a tomar conhecimento, sempre que julgar relevante, dos elementos informativos e das razões constitucionais daqueles que, embora não tenham legitimidade para deflagrar o processo, serão destinatários diretos ou mediatos da decisão a ser proferida. Visa-se, ademais, a alcançar um patamar mais elevado de legitimidade nas deliberações do Tribunal Constitucional, que passará formalmente a ter o dever de apreciar e dar a devida consideração às interpretações constitucionais que emanam dos diversos setores da sociedade." 218 (Grifamos)

Portanto, além de servir para auxiliar no julgamento da ação, fornecendo ao STF dados e informações novas e relevantes para a decisão, o amicus curiae tem, também, a função de possibilitar que outros, que não apenas os legitimados a propor a ação, sejam ouvidos, pluralizando o debate na jurisdição constitucional concentrada e favorecendo o acréscimo de legitimidade democrática à decisão.

Esse papel do amicus curiae é comentado e celebrado não só pela doutrina ${ }^{219}$ como pela própria jurisprudência do $\mathrm{STF}^{220}$ :

"Essa inovação institucional (amicus curiae), além de contribuir para a qualidade da prestação jurisdicional, garante novas possibilidades de

\footnotetext{
${ }^{218}$ Gustavo Binenbojm, "A dimensão do amicus curiae no processo constitucional brasileiro: Requisitos, poderes processuais e aplicabilidade no âmbito estadual", p.3.

${ }^{219}$ Ver também Anna Candida da Cunha Ferraz, "O amicus curiae e a democratização e a legitimação da jurisdição Constitucional concentrada", p.72; Thais Catib De Laurentiis, Op. cit., p.72; Ana Letícia Queiroga de Mattos, Op. cit., p.3; etc.

${ }^{220}$ No mesmo sentido, ver ementa da ADI 2323-Mc.
} 
legitimação dos julgamentos do Tribunal no âmbito de sua tarefa precípua de guarda da Constituição.",221

\subsubsection{Diferenças entre amicus curiae e audiência pública}

Como se pôde notar, as funções desse instituto em muito se parecem com as da audiência pública, já estudadas. Essa semelhança quanto às funções faz com que alguns autores $^{222}$ entendam que os institutos do amicus curiae e da audiência pública se confundem, ou ainda que esta constitua uma espécie e, aquele, gênero.

Como já afirmado aqui ${ }^{223}$, este trabalho defende que, apesar de visarem ao mesmo objetivo - subsidiar o julgamento da ação fornecendo informações e auxiliar no acréscimo de legitimidade democrática do Tribunal -, seus requisitos e características fazem deles dois instrumentos distintos. Entre os aspectos que os diferenciam - alguns dos quais serão aprofundados mais para frente ainda neste capítulo - destacam-se:

1) Quanto à forma de ingresso, viu-se que na audiência pública ela varia conforme o modelo adotado pelo Ministro que presidi-la: os participantes podem ser indicados pelas partes, pelo próprio Ministro e até mesmo pelos amici curiae admitidos, ou pode-se abrir as portas do Tribunal para que qualquer interessado inscreva-se para participar. Já para aqueles que desejam intervir como amicus curiae, basta que peticionem ao STF.

2) Quanto aos requisitos considerados para a admissão, para a audiência pública a lei estabelece apenas que a pessoa deve ter experiência ou autoridade no tema discutido, tendo o Ministro relator discricionariedade para admiti-la ou não. Para o ingresso do amicus curiae, porém, a lei exige que haja relevância da matéria discutida, representatividade do postulante e manifestação dentro do prazo

\footnotetext{
221 Decisão proferida pelo Ministro Gilmar Mendes na ADI 3842, disponível em http://www.stf.jus.br/portal/processo/verProcessoTexto.asp?id=2727074\&tipoApp=RTF

${ }^{222}$ Cássio Scarpinella Bueno, Op. cit., p.185; Thais Catib De Laurentiis, Op. cit., p.59; Mônia Clarissa Henning Leal, Rosana Helena Maas, "Audiência pública realizada pelo Supremo Tribunal Federal sobre a lei de biossegurança como forma de ocorrência da figura do amicus curiae", Revista de Estudos Constitucionais, Hermenêutica e Teoria do Direito (RECHTD), jan./jun. 2010; Sociedade Brasileira de Direito Público, Op. cit., p.185. ${ }^{223}$ Ver p.65.
} 
determinado, além da exigência jurisprudencial de informação nova e relevante, ficando a critério do relator a admissão.

3) Quanto ao momento e forma de participação, na audiência pública o participante manifesta-se apenas durante o evento, oralmente, pelo tempo estabelecido pelo Ministro que a presidir; em algumas audiências admitiu-se a apresentação de documentos. Já o amicus curiae pode participar apresentando razões, manifestação por escrito, documentos, sustentação oral e, por vezes, são responsáveis por indicar especialistas para serem ouvidos nas audiências públicas; para alguns, como já visto, o amicus possui ainda o direito de recorrer e de requerer providências instrutórias.

4) Quanto às limitações impostas, como visto, na maior parte das audiências realizadas até o momento as exposições dos participantes sofreram algum tipo de limitação: proibiu-se a discussão de questões jurídicas ou restringiu-se a manifestação a questões pré-formuladas. Já o amicus curiae é livre para manifestar-se sobre o que quiser dentro dos atos processuais que pode realizar.

A partir desses pontos, pode-se concluir que o amicus curiae apresenta-se como instrumento que possibilita uma participação mais ampla em termos de interação e temas a serem tratados. No entanto, é justamente por permitir um maior grau de interferência no processo que a admissibilidade dessa forma de participação é mais restrita, sendo os requisitos para ingresso mais rigorosos e, consequentemente, o número de participantes mais reduzido, de modo a não comprometer a celeridade e exequibilidade processual.

Para se constatar em que medida esse instrumento pode, de fato, contribuir com o acréscimo de legitimidade democrática às decisões do STF, entretanto, é importante um estudo de como se dá sua admissão no processo.

\subsection{Requisitos de admissibilidade}

Antes de analisar os requisitos de admissibilidade do amicus curiae, vale lembrar que não há um direito subjetivo das entidades e órgãos de ingressarem como amicus, 
ficando a admissão desses, na prática, a critério do Ministro Relator, que deve fundamentar e justificar sua decisão.

Se a Lei 9.882/99 não menciona requisitos para a admissão desse instrumento, a Lei 9.868/99, por sua vez, apresenta três: relevância da matéria e representatividade dos postulantes, além do discutido prazo para ingresso no processo. Se para alguns, em razão do silêncio da Lei 9.882/99, a ADPF não apresenta critérios bem delimitados ${ }^{224}$ para a admissão de amicus, para o STF isso não tem sido motivo para deixar de aplicar tais requisitos também para esse tipo de ação, por analogia ${ }^{225}$.

Além desses requisitos legais, a análise jurisprudencial permite a identificação de um quarto requistito: o oferecimento de informação nova e relevante. A seguir serão explicados cada um deles.

A) Relevância da matéria

Quanto à verificação do preenchimento do requisito relevância da matéria, em razão de sua subjetividade, há sérias divergências tanto na doutrina quanto na jurisprudência.

Edgar Silveira Bueno Filho, por exemplo, assim se manifesta:

“Temos para nós que por relevância da matéria o legislador quis que o postulante demonstrasse a relação de relevância entre a matéria discutida e a atividade perseguida pela instituição. Primeiro porque, se o processo está em andamento é porque é relevante a matéria. Com efeito, não se pode imaginar um processo de controle de constitucionalidade de matéria irrelevante. Depois, porque não teria sentido admitir-se a presença de terceiros na lide sem um mínimo de interesse jurídico no desfecho da causa a favor ou contra uma das partes.",226

Refutando, justamente, a passagem acima transcrita, Ana Letícia Queiroga de Mattos discorda "do entendimento de que seja necessário que a pessoa/órgão/entidade

\footnotetext{
${ }^{224}$ Thais Catib De Laurentiis, Op. cit., p.47.

${ }^{225}$ Assim também entende Eloísa Machado de Almeida, Op. cit., p.38.

${ }^{226}$ Edgar Silveira Bueno Filho, "Amicus Curiae: A Democratização do Debate nos Processos de Controle de Constitucionalidade”, Revista Diálogo Jurídico, n¹4, jun./ago. 2002, pp.6-7.
} 
demonstre a relação entre relevância da matéria em discussão no processo e a atividade exercida pela instituição" já que dessa forma "estar-se-ia falando em pertinência temática", e assim, "ao invés de se ampliar a discussão estar-se-ia restringindo o debate novamente ao rol fechado do art. 103, CF/88,227.

Quanto a essa última afirmação, porém, cabe uma breve observação. A pertinência temática, como será estudada em capítulo referente ao rol de legitimados para propor as ações de controle concentrado de constitucionalidade ${ }^{228}$, é apenas um dos diversos requisitos para a admissão de alguns dos legitimados . Logo, sua aplicação também para o ingresso de amicus curiae, embora restrinja a participação, não a limita ao rol do artigo 103 da Constituição Federal.

Como constata Damares Medina a partir de pesquisa empírica analisada, são os atores originalmente excluídos da jurisdição constitucional concentrada que buscam o ingresso como amicus curiae, e não aqueles já legitimados para acionar o controle de constitucionalidade $^{229}$.

Fato é que nem mesmo na jurisprudência do Supremo Tribunal Federal é possível encontrar um entendimento uníssono. Assim, há decisões que negam o ingresso do amicus em razão da ausência de relevância da matéria sem explicar o que entendem por relevante, outras que deferem o pedido sem motivá-lo.

Ao analisar as decisões fundamentadas do STF com relação ao ingresso do amicus curiae, Thais Catib De Laurentiis constata que, quando tal intrumento é admitido no processo, os Ministros referem-se a ao menos uma das seguintes situações ao analisarem a relevância da matéria ${ }^{230}$ : a) existência de situação concreta para ensejar a participação do amicus curiae; b) o tema em questão ser de alta indagação; c) a discussão ser suficiente para que o relator sinta a necessidade de recolhimento de mais informações; d) o caso possuir complexidade; e) a existência de repercussão na ordem pública.

\footnotetext{
${ }^{227}$ Ana Letícia Queiroga de Mattos, Op. cit., p.179.

${ }^{228}$ Ver pp.118 e seguintes.

${ }^{229}$ O que, segundo a autora, seria uma das muitas diferenças do uso desse instituto no Brasil e nos Estados Unidos, "onde o amicus surge como forma de viabilizar a participação do Estado e demais entes federativos nas disputas individuais que surtiriam imediato reflexo no sistema federativo" (Damares Medina, Op. cit., pp.117-118)

${ }^{230}$ Thais Catib De Laurentiis, Op. cit., p.35.
} 
As cinco hipóteses acima descritas não ajudam a formular uma definição do que seria matéria de grande relevância para o STF; pelo contrário, ressaltam o caráter subjetivo de tal requisito, cabendo ao Ministro relator, portanto, decidir quando entende presente tal situação.

A complexidade da questão pode ser percebida com a leitura de decisão do Ministro Marco Aurélio a respeito de requerimento para ingresso como amicus curiae na ADI 3185. Nesta ação, proposta pelo Procurador-Geral da República em atendimento à solicitação do Sindicato dos Trabalhadores e Servidores Públicos do Estado do Espírito Santo, foram impugnados artigos de lei estadual que criava cargos de provimento em comissão, o que, pelo entendimento do autor, violaria o artigo 37 da Constituição Federal, já que tais cargos não deveriam ser preenchidos dessa maneira, mas sim por meio de concurso público.

Em petição para ingresso como amicus, de autoria do mesmo Sindicato que solicitou ao Procurador-Geral da República a referida ADI, assim decidiu o Ministro:

"A regra é não se admitir intervenção de terceiros no processo de ação direta de inconstitucionalidade, iniludivelmente objetivo. A exceção corre à conta de parâmetros reveladores da relevância da matéria e da representatividade do terceiro, quando, então, por decisão irrecorrível, é possível a manifestação de órgãos ou entidades - artigo $7^{\circ}$ da Lei $\mathrm{n}^{\circ}$ 9.868, de 10 de novembro de 1999. No caso, está em jogo diploma que versa sobre a criação de cargos de provimento em comissão e de funções gratificadas. Inexiste situação concreta a ensejar a participação do Sindicato, por maior que seja a representatividade. Em síntese, não se mostra necessária, diante da envergadura do tema em discussão, a manifestação de órgãos ou entidades. 3. Indefiro o pleito"231 (Grifamos)

Vê-se que nessa decisão, em que pese a representatividade do postulante e a evidente relação entre a matéria discutida e a atividade perseguida pela instituição, decidiu o Ministro não ser admissível o amicus curiae justamente por entender tal manifestação desnecessária ao analisar a relevância da matéria.

${ }^{231}$ Ver decisão na seção Acompanhamento Processual, no site do STF. 
B) Representatividade do postulante

O outro critério previsto na Lei 9.868/99, a representatividade do postulante, dá margem a uma discussão ainda maior já que, além de subjetivo, refere-se muito mais à pessoa que pretende ser amicus do que à matéria discutida, devendo assim ser apreciada a cada requerimento.

Considerando que cabe ao relator interpretar o que entende por "representatividade" daquele que pretende ingressar como amicus, não é possível estabelecer um conceito para tal requisito. Entretanto uma análise jurisprudencial permite traçar os parâmetros utilizados pelos Ministros, como se verá a seguir.

Tendo como base somente as petições e os documentos apresentados pelo amicus, os relatores se atêm especialmente à análise do Estatuto Social do postulante - quando este é pessoa jurídica -, para constatar se entre sua finalidade e o conteúdo da norma ou ato impugnado pela ação existe uma compatibilidade.

Há quem entenda ${ }^{232}$ que, sob tal enfoque, esse requisito se assemelha à pertinência temática adotada pelo Supremo Tribunal Federal para a propositura de ação direta de controle de constitucionalidade pelos legitimados especiais ${ }^{233}$. Não sendo demonstrada, portanto, a compatibilidade entre os interesses do postulante e os que estão sendo discutidos na ação, não se admite o amicus curiae.

Além desse entendimento, a análise do Estatuto Social tem ainda outra serventia: verificar se ele não dispõe exclusivamente de cláusulas corporativistas que visam à defesa apenas de interesses individuais.

Isso porque, da pesquisa jurisprudencial depreende-se que, para o STF, "o amicus curiae deve atender a interesses gerais e coletivos, não servindo para veicular questões

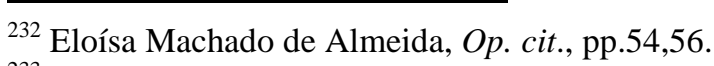

${ }^{233}$ A questão da pertinência temática será tratada no capítulo referente ao rol de legitimados. Ver pp.118 e seguintes.
} 
de ordem subjetiva ou demandas corporativas" ${ }^{234}$. Esse entendimento é válido tanto para pessoas jurídicas quanto para pessoas físicas.

Nesse sentido vão as decisões dos Ministros Joaquim Barbosa, na ADI 3311, e Marco Aurélio, na ADI 3522.

No primeiro caso, a ação foi proposta pela Confederação Nacional da Indústria e impugnava lei que criava limitações à publicidade de produtos relacionados ao tabaco, entendendo a autora que a norma, em verdade, vedaria tal publicidade, violando o direito de livre iniciativa, a liberdade de expressão, entre outras garantias constitucionais.

Nesse contexto, o pedido de intervenção como amicus curiae feito pelo Sindicato dos Médicos do Distrito Federal foi indeferido, tendo como uma de suas justificativas a seguinte:

“Ademais, o SINDIMÉDICO não logrou demonstrar que detém experiência e autoridade em matéria de saúde social, uma vez que dentre as suas 'prerrogativas', elencadas no art. $2^{\circ}$ de seu Estatuto, figuram apenas disposições de caráter eminentemente coorporativas e de interesse próprio da categoria, como por exemplo: '(a) representar, perante autoridade administrativas e judiciárias os interesses gerais e individuais da categoria dos médicos, podendo promover ações de representação e substituição processual de toda a categoria, médicos sócios e não sócios, inclusive da defesa dos direitos difusos e dos direitos do consumidor; (b) celebrar convenções e acordos coletivos de trabalho e colaborar nas comissões de conciliação e tribunais de trabalho; (c) adotar medidas de utilidade e beneficência para os seus associados de acordo com os regulamento que forem elaborados', entre outros. Do exposto, indefiro o pedido." ${ }^{, 235}$ (Grifamos)

Já a ADI 3522 foi interposta pelo Procurador-Geral da República visando a impugnação de lei do Estado do Rio Grande do Sul que violaria o príncipio da isonomia, previsto no

\footnotetext{
${ }^{234}$ Eloísa Machado de Almeida, Op. cit., p.57.

${ }^{235}$ Ver decisão na seção Acompanhamento Processual, no site do STF.
} 
artigo $5^{\circ}$ da Constituição Federal, por conferir maior pontuação em concurso público àqueles que tivessem exercido, anteriormente, atividade relacionada com a área notorial ou de registro.

Em indeferimento de pedido de ingresso como amici curiae de três pessoas aprovadas em concurso em que tais normas foram aplicadas, argumentou-se:

“Observe-se que, consoante dispõe o artigo $7^{\circ}$ da Lei $n^{\circ}$ 9.868/99, a regra é a inadmissibilidade da intervenção de terceiros no processo revelador da ação direta de inconstitucionalidade. Em situações excepcionais, possível é tal participação. No caso, os requerentes são interessados sob o ângulo jurídico, é certo, no desfecho do julgamento. Todavia, a manifestação prevista no $\S 2^{\circ}$ do artigo $7^{\circ}$ da Lei $n^{\circ} 9.868 / 99$ visa a esclarecimentos de órgão ou entidade, e não a defesa de interesse individual. 3. Indefiro o pedido." (Grifamos)

O trabalho de Thais Catib de Laurentiis traz ainda curiosas decisões quanto à representatividade de postulantes que se dedicavam ao estudo da matéria discutida mas que não representavam nenhuma entidade em especial. Nesses casos, referentes às ADIs 3421 e 3510, respectivamente, o pedido de participação como amicus foi indeferido, mas a motivação apresentada na decisão é insuficiente, como se verá.

Na ADI 3421, de autoria do Governador do Estado do Paraná, foram impugnados artigos de lei do Estado que estabeleciam benefícios fiscais a igrejas e templos de qualquer natureza. No entendimento do autor, esses dispositivos feririam os artigos 150, $\S 6^{\circ}$ e $155, \S 2^{\circ}$, XII, g da Constituição Federal.

Entre os pedidos de ingresso de amici curiae, constava o de um professor de Direito que realizou mestrado, especialização e outras pesquisas científicas sobre a imunidade dos templos de qualquer culto. Seu requerimento foi indeferido sob o seguinte argumento:

"Consigne-se a excepcionalidade da intervenção de terceiro no processo objetivo revelador de ação direta de inconstitucionalidade. Cumpre ao relator definir a conveniência de tal participação. Isso não ocorre na espécie. 
Eis como veio a ser justificado o pedido: O Sr. Daniel Araújo Lima, por ser professor de direito e estudioso específico da matéria aqui discutida, detém notória legitimidade processual para integrar a presente ADIN na qualidade de amicus curiae, haja vista que desenvolveu e desenvolve, em sede de Especialização e Mestrado, pesquisas científicas sobre a Imunidade dos Templos de Qualquer Culto. Em jogo tem-se o conflito de Lei estadual - $\mathrm{n}^{\text {o }}$ 14.586/04 do Estado do Paraná - com o Diploma Fundamental. Por mais elogiável que seja o objetivo almejado, não cabe a admissão pretendida. 3. Indefiro o pleito." 236 (Grifamos)

Já a ADI 3510, estudada no tópico refente às audiências públicas, foi impetrada pelo Procurador-Geral da República e questionou a constitucionalidade de lei que permitia pesquisas com células-tronco embrionárias. Entre os pedidos de ingresso como amicus curiae, o de um estudioso de questões jurídicas relacionadas à utilização do embrião humano foi assim indeferido:

"Reginaldo da Luz Ghisolfi requer a sua admissão na presente ação direta de inconstitucionalidade na qualidade de amicus curiae. Para tanto, alega que há anos vem estudando as questões relacionadas à utilização do embrião humano (...). O $\S 2^{\circ}$ do art. $7^{\circ}$ da lei 9868/99 autoriza o relator da ação direta de inconstitucionalidade, considerando a relevância da matéria e a representatividade dos postulantes, a admitir a manifestação de outros órgãos ou entidades. Sucede que esse não é o caso dos autos. Ainda que patente a relevância da matéria aqui veiculada, é incontroversa a falta de representatividade do postulante, razão porque indefiro o seu pedido. Isso não obstante, recebo a peça apresentada como memorial e determino à secretaria que promova a sua juntada por linha." 237 (Grifamos)

C) Prazo para ingresso

\footnotetext{
${ }^{236}$ Ver decisão na seção Acompanhamento Processual, no site do STF.

${ }^{237}$ Ver seção Acompanhamento Processual da ADI 3510 em 05/05/2006, no site do STF.
} 
A lei faz ainda menção a outro fator, o prazo para ingresso no processo, mas há discussão tanto na doutrina quanto na jurisprudência se esse seria um requisito para a admissibilidade do amicus curiae.

Como já mencionado, o art. $7^{\circ}, \S^{\circ}$ da Lei 9.868/99, vetado pelo Presidente da República, fazia referência ao prazo de 30 dias, contados do recebimento do pedido, previsto para a prestação de informações, que, conforme o $\S 2^{\circ}$, também se aplicaria ao amicus curiae:

“Art. $6^{0} \mathrm{O}$ relator pedirá informações aos órgãos ou às autoridades das quais emanou a lei ou o ato normativo impugnado.

\section{Parágrafo único. As informações serão prestadas no prazo de trinta dias contado do recebimento do pedido.}

Art. $7^{0}$ Não se admitirá intervenção de terceiros no processo de ação direta de inconstitucionalidade.

$\S 1^{\underline{0}}$ Os demais titulares referidos no art. $2^{\underline{0}}$ poderão manifestar-se, por escrito, sobre o objeto da ação e pedir a juntada de documentos reputados úteis para o exame da matéria, no prazo das informações, bem como apresentar memoriais. (VETADO)

$\S 2^{\underline{0}} \mathrm{O}$ relator, considerando a relevância da matéria e a representatividade dos postulantes, poderá, por despacho irrecorrível, admitir, observado o prazo fixado no parágrafo anterior, a manifestação de outros órgãos ou entidades." (Grifamos)

Como foi explicado nas razões do veto ${ }^{238}$, entretanto, esse não alterou a compreensão da matéria, de modo que, também para o amicus curiae aplica-se o prazo de 30 dias. A divergência, porém, se dá com relação ao momento em que o amicus ingressará no processo.

Há quem admita que o oferecimento do amicus curiae pode se dar em qualquer momento do processo, desde que antes de iniciado o julgamento, devendo o amicus, porém, se manifestar no prazo de 30 dias contados da data da publicação da decisão que admite sua intervenção.

\footnotetext{
238 "Cabe observar que o veto repercute na compreensão do $\S 2^{\circ}$ do mesmo artigo, na parte em que este enuncia 'observado o prazo fixado no parágrafo anterior'. Entretanto, eventual dúvida poderá ser superada com a utilização do prazo das informações previsto no parágrafo único do art. $6^{\circ}$." (Razões do veto da Lei 9.868/99)
} 
Assim defende, entre outros ${ }^{239}$, Gustavo Binenbojm:

"Dessa forma, a oportunidade processual para a admissão dos amici curiae, nos termos do art. $7^{\circ}, \S 2^{\circ}$, não se exaure com o término do prazo para as autoridades prestarem informações (art. $6^{\circ}$, parágrafo único). Decorre da sistemática da lei que o amicus curiae poderá ser admitido a qualquer tempo, antes de iniciado o julgamento final da ação. O prazo a que se refere o $\S 2^{\circ}$ do art. $7^{\circ}$ não é para a definição do momento processual da admissão do amicus curiae, mas para a apresentação da sua manifestação escrita a partir da data da decisão positiva do relator.,"240

Conforme essa compreensão, o postulante poderia, desde que antes do início do julgamento, requerer seu ingresso no feito. A partir da decisão admitindo sua intervenção, o amicus pegaria o processo no estado em que se encontrasse e teria até 30 dias para manifestar-se.

Rebatendo essa ideia, Eloísa Machado de Almeida afirma não entender "adequada a ideia de que pode ser juntado a qualquer tempo o amicus curiae e de que o prazo para recebimento seria de 30 (trinta) dias contados da admissão por parte do relator, até porque a análise de pertinência da manifestação tem se dado no mérito dos amici, ou seja, a admissão se dá no mesmo momento do oferecimento das razões"241.

Por essa razão, defende que o prazo para oferecimento do amicus curiae seria o mesmo previsto para a instrução da ação: 30 dias. Passado esse período, não seria mais possível requerer a intevenção no processo por meio de tal instrumento.

No STF também existem divergências entre os julgados, como sintetiza despacho da Ministra Ellen Gracie apreciando a admissibilidade de um postulante:

"Exatamente pelo reconhecimento da alta relevância do papel em exame é que o Supremo Tribunal Federal tem proferido decisões admitindo o ingresso desses atores na causa após o termino do prazo para

\footnotetext{
${ }^{239}$ No mesmo sentido, ver Ana Letícia Queiroga de Mattos, Op. cit., p.193.

${ }^{240}$ Gustavo Binenbojm, "A dimensão do amicus curiae no processo constitucional brasileiro: Requisitos, poderes processuais e aplicabilidade no âmbito estadual”, p.11.

${ }^{241}$ Eloísa Machado de Almeida, Op. cit., p.37.
} 
informações (ADI 3.474, rel. Min. Cezar Peluso, DJ 19.10.05), após a inclusão do feito na pauta de julgamento (ADI 2.548, rel. Min. Gilmar Mendes, DJ 24.10.05) e, até mesmo, quando já iniciado o julgamento, para a realização de sustentação oral, logo depois da leitura do relatório, na forma prevista no artigo 131, $3^{\circ}$ do RISTF (ADI 2777-QO, rel. Min. Cezar Peluso). ${ }^{242}$ (Grifamos)

Em julgamento de questão de ordem na ADI 4071, porém, o Tribunal firmou seu entendimento mais recente, admitindo o ingresso do amicus curiae até o momento da inclusão do processo em pauta, já que, passado esse momento, sua manifestação seria pouco oportuna, uma vez que o voto do relator já teria sido elaborado.

Seja antes ou depois do posicionamento firmado pelo Supremo Tribunal Federal, o prazo para ingresso deve ser visto como um dos requisitos para a admissão, já que resulta no indeferimento de diversos pedidos de participação ${ }^{243}$. Embora seu entendimento pela jurisprudência não seja exatamente como previsto em lei - de 30 dias - neste trabalho será compreendido como um dos requisitos legais para o ingresso do amicus, já que a lei prevê um limite temporal para sua manifestação.

D) Oferecimento de informação nova e relevante

Não obstante serem esses três - relevância da matéria, representatividade do postulante e prazo para manifestação - os requisitos previstos no texto normativo, uma análise jurisprudencial mostra a existência de outro critério utilizado como filtro para o ingresso do amicus curiae pelo Tribunal.

É dessa forma que alguns julgados indicam como requisito essencial à admissão do amicus o oferecimento de informações relevantes que ainda não foram levantadas pelas partes nos autos. Ou seja, mesmo sem previsão legal, os Ministros criam restrição à participação democrática no controle jurisdicional de constitucionalidade.

\footnotetext{
${ }^{242}$ Ver despacho de 27/06/06 na ADI 2316, disponível na seção Acompanhamento Processual do site do STF.

${ }^{243}$ Ver Damares Medina, Op. cit., pp.86-87 e Thais Catib De Laurentiis, Op. cit., p.27.
} 
A simples reiteração das razões da petição inicial, sem o acréscimo de nenhum outro subsídio fático ou jurídico, tem acarretado o indeferimento do postulante, como demonstra a decisão do Ministro Joaquim Barbosa na ADI 3410.

$\mathrm{Na}$ ação, interposta pelo Governador do Estado do Paraná, foi impugnado ato normativo do Estado de Minas Gerais que, segundo o autor, criou barreira tributária para impedir a entrada de farinha de trigo oriunda de outras unidades federadas, violando assim o artigo 152 da Constituição Federal, entre outros dispositivos. Em resposta a pedido do Sindicato dos Moinhos de Trigo do Estado de Minas Gerais, assim decidiu o STF:

“Trata-se de requerimento apresentado pelo SINDICATO DOS MOINHOS DE TRIGO DO ESTADO DE MINAS GERAIS para admissão da entidade como amicus curiae nos autos da ADI 3.410, que versa sobre a constitucionalidade do Decreto 43.891/2004 do estado de Minas Gerais. (...) A mera manifestação de interesse em integrar o feito, sem o acréscimo de nenhum outro subsídio fático ou jurídico relevante para o julgamento da causa, não justifica a admissão de postulante como amicus curiae. A requerente não demonstra como poderia contribuir de forma suplementar às razões oferecidas pelo requerente ou pelo requerido, tampouco oferece outro subsídio fático ou jurídico relevante para o julgamento da causa. Do exposto, indefiro o requerimento para inclusão da requerente como amicus curiae." 244 (Grifamos)

Como destaca Damares Medina ${ }^{245}$, esse requisito dialoga com outro aqui já apresentado, o da representatividade do postulante, mas desse se diferencia, já que, ainda que ele demonstre representar interesses gerais e coletivos, e que haja relação entre os interesses defendidos pela entidade e o tema discutido na ação, isso não implica no fornecimento de novo material fático ou jurídico. Trata-se, portanto, de mais um entrave à participação da sociedade como amicus curiae, além daqueles já previstos na lei.

\footnotetext{
${ }^{244}$ Ver decisão na seção Acompanhamento Processual, no site do STF.

${ }^{245}$ Damares Medina, Op. cit., p.86.
} 
Assim, pode-se concluir que são quatro os requisitos para ingresso do amicus na jurisdição constitucional concentrada, ainda que haja variações quanto a sua interpretação:

1) Legais: a) Relevância da matéria, b) Representatividade do postulante, c) Prazo para ingresso (todos no art. $7^{\circ}, \S 2^{\circ}$ da Lei 9.868/99).

2) Jurisprudencial: Acréscimo de informação nova e relevante.

\subsection{Análise crítica do amicus curiae}

A partir da conceituação do amicus curiae e dos requisitos acima vistos, faz-se pertinente a análise de alguns dados relativos ao perfil de quem se utiliza desse instrumento.

Em pesquisa realizada com pedidos de ingresso de amicus entre 1999 a 2005, Eloísa Machado de Almeida identificou entre os postulantes ${ }^{246}$ : unidades da Federação Municípios, Estados e União -, órgãos da administração pública, membros e comissões do Poder Legislativo, Tribunais do Poder Judiciário, Tribunais de Contas, Conselhos de Direitos, Ministério Público, Defensorias Públicas e Procuradorias de Assistência Judiciária, associações civis de classe ou profissionais, organizações não governamentais sem fins lucrativos, federações de empresas ou de atividades econômicas, empresas propriamente ditas, além de especialistas e partidos políticos.

Dentre esses, a autora delimitou um grupo específico, chamado de 'associações civis' ou simplesmente 'sociedade civil' ${ }^{247}$, composto por associações de classe ou profissionais, organizações não-governamentais sem fins lucrativos de proteção de direitos e também por associações de empresas ou de atividades econômicas ${ }^{248}$.

\footnotetext{
${ }^{246}$ Eloísa Machado de Almeida, Op. cit., p. 69.

${ }^{247}$ Ibidem, p.77.

248 Essas "não se tratam das empresas propriamente ditas ou de conglomerados econômicos, mas organizações sociais com o objetivo de defesa de seus interesses no debate público, havendo, assim, maior afinidade com a configuração de ator da sociedade civil” (Ibidem, p.77).
} 
Analisando todos os pedidos formulados dentro do período estudado, concluiu que as associações civis foram responsáveis por mais de $70 \%$ dos amici curiae propostos nas $\mathrm{ADIs}^{249}$ e mais de $85 \%$ nas $\mathrm{ADPFs}^{250}$.

Chama atenção ainda o fato de apenas $33 \%$ de todos os pedidos para ingresso de amicus em ADIs terem sido propostos por aqueles legitimados para a propositura da ação ${ }^{251}$, conforme o rol do artigo 103 da Constituição Federal. Já entre as associações civis, apenas em $46 \%$ de todos os pedidos formulados os postulantes preencheriam os requisitos para propositura da ação ${ }^{252}$.

Essas informações indicam "que havia uma demanda de acesso à jurisdição constitucional que estava reprimida pela legitimação de apenas outros atores" ${ }^{253}$. Ou seja, ainda que tenha contribuído, em algum grau, com a democratização da jurisdição constitucional concentrada, a ampliação do rol de legitimados do artigo 103 da Constituição não foi suficiente para tanto, deixando espaço para que o instituto do amicus curiae preenchesse essa demanda.

Resta, portanto, verificar se tal instituto cumpre de fato com essa expectativa, a partir da análise da admissão do amicus, sua forma de intervir no processo e a maneira como tal participação é considerada pelos Ministros.

Como visto, os dados acima comentados referem-se apenas à propositura de amicus curiae. Desses pedidos de ingresso, estima-se que $33 \%$ são indeferidos ${ }^{254}$ em razão da não verificação de algum dos requisitos de admissão: relevância da matéria, representatividade do postulante, observância do prazo para manifestação e presença de informação nova e relevante.

\footnotetext{
${ }^{249}$ Eloísa Machado de Almeida, Op. cit., p.77.

${ }^{250}$ Ibidem, p.84.

${ }^{251}$ Ibidem, p.72.

${ }^{252}$ Ibidem, p.79.

${ }^{253}$ Ibidem, p.89.

${ }^{254}$ Em pesquisa realizada com os pedidos de ingresso de amicus até agosto de 2007, Thais Catib De Laurentiis conclui que aproximadamente $33 \%$ do total de pedidos efetuados são indeferidos (Op. cit., p. 19). Na verdade a quantidade de pedidos realizados e indeferidos é ainda maior, mas a pesquisadora exclui de sua análise aqueles que foram indeferidos em razão do decurso do prazo para informações $(O p$. cit., p.27), considerado neste trabalho como um dos requisitos para admissão do amicus curiae, ainda que por vezes tenha sido ignorado pela jurisprudência, como visto.
} 
É certo que "tendo em conta a progressiva ampliação e abertura da jurisdição constitucional e o princípio democrático de nosso Estado de Direito, a participação como amicus curiae, sempre que requisitada e de acordo com os critérios formais, deve ser aceita" ${ }^{\text {255 }}$. Percebe-se, porém, que a escassa regulamentação do tema, seja por meio de leis ou pelo Regimento Interno do STF, permitiu uma interpretação restritiva dos requisitos para admissão do amicus curiae, além de decisões contraditórias por parte dos Ministros.

Se com o passar dos anos o Tribunal vem mudando esse entendimento com relação a alguns dos critérios e permitindo uma maior abertura, como se viu com relação ao prazo para manifestação do amicus $^{256}$, o mesmo não se pode afirmar com relação aos demais requisitos, em que a discricionariedade do Relator por vezes prevalece sobre um dos objetivos principais do instituto: a pluralização do debate.

Exemplos claros dessa restrição são casos como os aqui já mencionados, em que o Ministro Relator, sem apresentar justificativa, nega a participação de postulante pessoa física alegando apenas que caberia ao Relator definir a conveniência da participação e concluindo: "por mais elogiável que seja o objetivo almejado, não cabe a admissão pretendida" 257 .

Nesses casos em que o postulante é pessoa física, aliás, a questão da discricionariedade na decisão é ainda mais complicada, já que, mesmo que o indeferimento seja justificado - o que não ocorreu nos casos citados neste trabalho - a análise da representatividade do postulante não apresenta parâmetros de avaliação como os existentes para as pessoas jurídicas - como visto, os Ministros baseiam-se nos Estatutos Sociais do postulante para verificar a presença desse requisito ${ }^{258}$.

Outro requisito para ingresso do amicus, a relevância da matéria baseia-se em critérios totalmente subjetivos - entendem os Ministros, por exemplo, que o tema deve ser de alta indagação, possuir complexidade ou ter gerado discussão suficiente para que eles

\footnotetext{
${ }^{255}$ Eloísa Machado de Almeida, Op. cit., p.39.

${ }^{256}$ Ver pp.95 e seguintes.

${ }^{257}$ Ver p.95.

${ }^{258}$ Ver pp. 92.
} 
sintam a necessidade de recolher mais informações ${ }^{259}$ - ficando o deferimento do pedido, portanto, à critério do Relator.

Se os requisitos previstos pela lei já impõem certas restrições à participação popular, à necessidade de trazer informação nova e relevante para o processo, criada pela jurisprudência, atua da mesma maneira. Vale notar que a inobservância desse requisito, porém, não torna a manifestação do amicus irrelevante para o processo, como explica Damares Medina:

"No acaso de simples reiteração de argumentos da parte, mesmo que não apresente informações novas, o amicus curiae contribui para demonstrar em que medida a decisão a ser tomada irá afetar segmentos que não estão figurando diretamente no processo. Por isso, ainda na hipótese de simplesmente reiterar os fundamentos de direito que já estão no processo, haveria uma utilidade no ingresso do amicus (grupos de interesses) que daria indícios acerca das preferências políticas do grupo social por ele representado." 260

Portanto, o amicus curiae admitido mesmo sem a observância desse requisito, ainda seria capaz de cumprir com uma das funções frequentemente relacionadas a esse instituto: possibilitar um acréscimo de legitimidade democrática nas decisões do Supremo Tribunal Federal.

A falta de uma maior regulamentação do instituto também pode interferir nos poderes processuais a ele concedidos.

Como visto, a possibilidade de realizar sustentação oral foi concedida após reiteradas decisões do Tribunal, chegando-se inclusive a alterar o Regimento Interno deste para garanti-la. Porém, viu-se também que, em razão do grande número de amicus admitidos em algumas ações ${ }^{261}$, e visando a garantir a celeridade processual, eles têm sido divididos em dois grupos - favoráveis e contrários à ação - que têm um tempo máximo estipulado para se manifestarem, devendo seus integrantes organizarem-se.

\footnotetext{
${ }^{259}$ Ver pp.90 e seguintes.

${ }^{260}$ Damares Medina, Op. cit., p.87.

${ }^{261}$ Damares Medina cita, por exemplo, a ADI 2999, que contou com 71 manifestações como amicus curiae. (Op. cit., p. 78 )
} 
Em que pese a necessidade de limitar o tempo para manifestações, sobretudo quando são muitos os amici participantes, cabe aqui a mesma crítica feita quanto à divisão dos expositores das audiências públicas ${ }^{262}$. Essa divisão em blocos antagônicos que visam à defesa de uma única posição sobre o caso tende a resumir, de forma simplista, os diversos posicionamentos possíveis em argumentos favoráveis ou contrários à constitucionalidade da lei ou ato, comprometendo tanto a função do instituto de fornecer informações que possam subsidiar os Ministros na tomada de decisão quanto a de acrescer legitimidade democrática ao STF.

É certo que no Brasil, como constatou Damares Medina em sua pesquisa, os amici curiae tendem a manifestar-se para apoiar um dos "lados" da disputa - razão pela qual a autora denomina-os de "amigos da parte" ao invés de "amigos da Corte" - sendo muitas vezes ignorado, portanto, seu caráter imparcial ${ }^{263}$. Ainda assim, não parece adequado que o próprio Tribunal force essa divisão em blocos antagônicos.

Outra questão a ser analisada diz respeito à capacidade de recorrer das decisões, que, como visto, não é reconhecida pelo Tribunal. A lei, entretanto, ao prever que o relator "poderá, por despacho irrecorrível, admitir"264 o ingresso do amicus curiae, possibilita uma interpretação muito mais favorável à participação popular: seria irrecorrível apenas a decisão que admite o amicus, cabendo recurso, portanto, das demais.

É esse o entendimento que defende Gustavo Binenbojm:

“A previsão da irrecorribilidade da decisão do relator se aplica, por óbvio, àquelas decisões de conteúdo positivo, pois o dispositivo menciona expressamente apenas como 'despacho irrecorrível' (rectius: trata-se de decisão interlocutória, e não de mero despacho) a decisão que admite a manifestação do amicus curiae. Por uma interpretação conforme à Constituição, que prestigie o direito ao contraditório e à ampla defesa, deve a Suprema Corte dar ao dispositivo a inteligência mais benéfica aos

\footnotetext{
${ }^{262}$ Ver pp.68-69.

${ }^{263}$ Damares Medina, Op. cit., p.169.

${ }^{264}$ Art. $7^{\circ}, \S 2^{\circ}$ da Lei $9868 / 99$.
} 
postulantes, permitindo-lhes que, por meio de agravo regimental, submetam a decisão indeferitória do relator ao Plenário."265

$\mathrm{Na}$ doutrina, há quem entenda que cabe recurso apenas das decisões que indeferem a participação $^{266}$, outros, com base na mesma interpretação, que também é possível ao amicus interpor qualquer recurso previsto pela legislação $\operatorname{processual}^{267}$, e ainda quem defenda a impossibilidade de interpor recurso, para não tornar inviável o processo ${ }^{268}$.

Se os critérios para a admissão do amicus curiae já são demasiadamente subjetivos, dando aos Ministros poder para interpretá-los livremente, deve-se, minimamente, permitir a impugnação da decisão sem fundamentação ou mal fundamentada que indeferir o ingresso, de forma que o membro do STF tenha ao menos que expor os motivos pelos quais entendeu não estarem presentes os requisitos de admissibilidade.

Por fim, há quem acredite em um dever formal do Tribunal de apreciar e dar a devida consideração às manifestações dos amici curiae $^{269}$, mas deve-se lembrar que, embora essencial para que o instituto cumpra com suas funções, não há qualquer obrigação dos Ministros em apreciar os argumentos trazidos pelos amici, ficando, novamente, à critério de cada membro do STF considerar ou não o que foi apresentado.

Neste ponto, parece pertinente a referência a alguns dados da pesquisa feita por Damares Medina. Na grande maioria das ações com manifestação de amicus curiae que analisou, os amici apoiavam apenas sua procedência ou improcedência, ou seja, havia manifestação do instituto em favor de apenas um dos "lados" da ação.

Comparando essas ações com aquelas em que não houve participação do amicus, verificou-se que nas ações nas quais os amici apoiavam a improcedência do pedido houve um aumento de mais de $15 \%$ de decisões pela improcedência da ação se comparadas àquelas em que não houve intervenção desse terceiro. Quando os amici

\footnotetext{
265 Gustavo Binenbojm, A Nova Jurisdição Constitucional Brasileira: Legitimidade democrática e Instrumentos de realização, p.164-165.

${ }^{266}$ Eloísa Machado de Almeida, Op. cit., p. 39.

${ }^{267}$ Gustavo Binenbojm, “A dimensão do amicus curiae no processo constitucional brasileiro: Requisitos, poderes processuais e aplicabilidade no âmbito estadual”, pp.17-19; Cássio Scarpinella Bueno, Op. cit., pp. 171-172.

${ }^{268}$ Damares Medina, Op. cit., p.78.

269 Gustavo Binenbojm, A Nova Jurisdição Constitucional Brasileira: Legitimidade democrática e Instrumentos de realização, p. 164; Ana Letícia Queiroga de Mattos, Op. cit., p.180.
} 
apoiavam a procedência da ação, constatou-se um aumento de $18 \%$ nas chances de procedência com relação às ações em que não houve manifestação de amicus $^{270}$.

Embora não haja vinculação entre os argumentos apresentados pelos amici e a decisão do Tribunal, a relação entre a intervenção desse instituto e o aumento das chances de êxito do "lado" por ele apoiado podem indicar, embora não seja possível afirmar, que sua manifestação é considerada pelos membros do STF no momento da decisão.

\subsection{Conclusão}

Em razão dessa discricionariedade conferida ao Ministro Relator, nota-se que o instituto pode ou não permitir a participação popular e favorecer o acréscimo de legitimidade democrática às decisões do STF, dependendo da maneira como sua participação for permitida pelos Ministros em cada situação.

Em relatório elaborado pela Sociedade Brasileira de Direito Público, concluiu-se, ao analisar "figuras processuais que, em tese, permitiriam uma abertura do STF à sociedade civil, o que, supõe-se, poderia conferir maior respaldo e legitimidade democrática às suas decisões", que "esses procedimentos decisórios são aplicados de maneira pouco equânime, estando muito atrelados ao critério exclusivo do relator, que possui total prerrogativa para decidir sobre o ingresso de um amicus curiae, ou admissão de um palestrante em audiência pública, por exemplo"271.

É esta a crítica sustentada por Damares Medina que, para tanto, diferencia a democratização da pluralização do processo:

"Ora, democratizar significa ampliar as condições objetivas de acesso. Foi o que se deu com a Constituição de 1988 e a ampliação do rol de legitimados para inaugurar o controle concentrado de constitucionalidade. (...) Contudo, no caso do amicus curiae, a permissão para a entrega de memoriais sempre foi mais um ato de boa vontade da corte que uma questão de direito. É que, em última análise, o ingresso do amicus curiae

\footnotetext{
${ }^{270}$ Damares Medina, Op. cit., pp.132-135.

${ }^{271}$ Sociedade Brasileira de Direito Público, Op. cit., pp.202-203.
} 
dependerá da vontade e da livre discricionariedade do juiz. Se não há de se falar em direito subjetivo ao acesso do amigo da corte à jurisdição constitucional, não há como falar em papel democratizador do amicus.

Pode-se dizer, sim, pluralização do debate, na medida em que outras luzes poderão iluminar o processo de tomada de decisão judicial. Contudo, essas luzes apenas poderão ser lançadas a partir do crivo discricionário do relator do processo." 272 (Grifamos)

Enquanto a autora critica o fato da participação do amicus ser tratada como um ato de boa vontade do Tribunal, Cássio Scarpinella Bueno afirma que "não há como negar que a jurisprudência do Supremo Tribunal Federal tem se mostrado generosa quanto à admissão do amicus curiae nas ações diretas de incontitucionalidade"273 (Grifamos).

Ainda que haja quem, como ele, entenda que o STF tem mantido suas portas abertas à participação popular por meio do amicus curiae, para que tal instituto possa de fato cumprir com essa função é necessária uma melhor regulamentação do tema, com a definição de critérios objetivos e poderes processuais bem delimitados. Essas garantias são essenciais para a sociedade, que não pode ficar a mercê da "generosidade" e da "boa vontade" do Supremo, cuja opinião, como se tem visto, é volátil.

Na regulamentação dessa matéria, sem dúvida o principal desafio será conciliar a democratização e a exequibilidade processual, de forma a permitir o maior grau de abertura e participação popular possível sem que o andamento do processo e da agenda do STF sejam comprometidos.

Entretanto, a respeito do argumento frequente de que um grande número de amici curiae inviabilizaria a atuação do Tribunal, Cássio Scarpinella Bueno conclui que "os trabalhos do Supremo Tribunal Federal não se inviabilizam porque, para o exercício de suas competências constitucionalmente traçadas, dá-se ouvido à sociedade civil organizada", porém "o Supremo Tribunal Federal inviabiliza-se, institucionalmente, quando não dá ouvidos à sociedade"274.

\footnotetext{
${ }^{272}$ Damares Medina, Op. cit., pp.75-76.

${ }^{273}$ Cássio Scarpinella Bueno, Op. cit., p.156.

${ }^{274}$ Ibidem, p. 167.
} 
Admitindo-se que o objetivo do amicus curiae é a democratização da jurisdição constitucional e uma maior legitimação democrática do STF, pode-se concluir que quanto mais forem ouvidos ${ }^{275}$ e quanto melhor for a qualidade dessa manifestação, mais próxima de tais finalidades estará a prestação jurisdicional constitucional.

${ }^{275}$ Nesse sentido, ver Ana Letícia Queiroga de Mattos, Op. cit., p.197. 


\section{Legitimados para propor ação direta de controle de constitucionalidade}

\subsection{Histórico normativo}

Desde a previsão no ordenamento jurídico brasileiro do controle concentrado de constitucionalidade, com a Emenda Constitucional n 16, de 26 de novembro de 1965, tinha-se o Procurador-Geral da República como único legitimado a propor a ação direta de inconstitucionalidade, sendo essa, até então, a única ação existente para provocar tal tipo de controle.

A grande discussão, à época, era se esse único legitimado, ao receber a manifestação de algum interessado acerca de uma inconstitucionalidade, tinha ou não discricionariedade para decidir se e quando ela deveria ser encaminhada por representação de inconstitucionalidade, ao Supremo Tribunal Federal ${ }^{276}$.

Antes da Constituição de 1988 o Procurador-Geral da República atuava não só como Chefe do Ministério Público mas também como representante judicial da União, nomeado pelo Presidente da República e podendo por este ser livremente exonerado. É verdade que a quantidade de ADIs propostas até 1988 não foi baixa, mas isso se deu apenas porque grande parte delas destinavam-se a aferir a constitucionalidade de leis estaduais que não iam de encontro aos interesses do Governo Federal ${ }^{277}$.

O que se contestava, portanto, era sobretudo a falta de neutralidade e independência desse único legitimado, e não o monopólio por ele exercido. O acesso da sociedade à jurisdição constitucional não era, à época, uma preocupação, como esclarece Anna Candida da Cunha Ferraz:

"Para o que interessa observar, todavia, não se questionou, em profundidade, a constitucionalidade, a 'democratização' ou a 'legitimidade'

\footnotetext{
${ }^{276}$ Sobre essa questão, ver Gilmar Ferreira Mendes, Jurisdição Constitucional: O controle abstrato de normas no Brasil e na Alemanha, pp.70-79.

277 Gilmar Ferreira Mendes cita as inúmeras representações que se destinavam a aferir a constitucionalidade de leis estaduais que criavam novos Municípios sem observar as exigências da Constituição ou que admitiam funcionários públicos sem a realização de concurso. (Ibidem, p.80)
} 
da jurisdição constitucional e nem se travaram grandes discussões sobre a incidência, ou não, da cláusula do amplo acesso à justiça nessa modalidade de controle, introduzida por Emenda Contitucional. O fato é que a não adoção da legitimidade universal já vinha assentada e definida, neste campo, desde sua origem européia, como se viu. A legitimação restrita para a propositura do controle abstrato era regra e, sob este aspecto, o modelo foi copiado no Brasil, ainda que com uma legitimação muitíssimo mais reduzida e, sob o ângulo do amplo acesso à justiça não ensejou maiores discussões." 278

Desde a concepção do controle concentrado de constitucionalidade já se entendia que era necessária uma legitimação restrita para acioná-lo, a fim de evitar ações temerárias e a sobrecarga da Corte ${ }^{279}$. Mas sendo o Brasil uma Federação - apresentando assim, além da legislação federal, diversas leis estaduais que devem respeitar os parâmetros constitucionais - e tendo a Constituição de 1988 visado, de maneira geral, à democratização e ampliação da participação, reconheceu-se que a previsão de um legitimado único e sem independência funcional não era apropriada.

Entre as alterações estabelecidadas pelo Constituinte de 1988 houve não só a separação das funções de representante judicial da União e Chefe do Ministério Público - ficando apenas essa última para o Procurador-Geral da República - como também a expansão do rol de legitimados a provocar o controle concentrado de constitucionalidade. Passouse, portanto, de um modelo de legitimidade exclusiva para o de legitimidade concorrente.

Para Luís Roberto Barroso, aliás, "foi no tocante à legitimação ativa para a propositura de ação direta de inconstitucionalidade que se operou a maior transformação no exercício da jurisdição constitucional no Brasil’"280.

Assim, o artigo 103 do texto constitucional trouxe em sua redação original os seguintes legitimados, além do próprio Procurador-Geral da República: o Presidente da

\footnotetext{
${ }^{278}$ Anna Candida da Cunha Ferraz, "O acesso à Jurisdição Constitucional como caminho para a sua democratização", p.491.

${ }^{279}$ Ver Gilmar Ferreira Mendes, Jurisdição Constitucional: O controle abstrato de normas no Brasil e na Alemanha, p.86; Anna Candida da Cunha Ferraz, Op. cit., p.490.

${ }^{280}$ Luís Roberto Barroso, O controle de constitucionalidade no Direito brasileiro, p.160.
} 
República, a Mesa do Senado Federal, a Mesa da Câmara dos Deputados, a Mesa de Assembleia Legislativa, o Governador de Estado, o Conselho Federal da Ordem dos Advogados do Brasil, partido político com representação no Congresso Nacional e confederação sindical ou entidade de classe no âmbito nacional.

Posteriormente, a Emenda Constitucional n 3, de 17 de março de 1993, instituiu a Ação Declaratória de Constitucionalidade ${ }^{281}$, e, em rol taxativo, delegou a proposição desta a um rol mais restrito:

“Art. 103 (...)

§ 4. ${ }^{\circ}$ A ação declaratória de constitucionalidade poderá ser proposta pelo Presidente da República, pela Mesa do Senado Federal, pela Mesa da Câmara dos Deputados ou pelo Procurador-Geral da República."

Em 1999, a Lei 9.868, que regulamenta a ação direta de inconstitucionalidade e a ação declaratória de constitucionalidade, trouxe o seguinte dispositivo:

“Art. $2^{0}$ Podem propor a ação direta de inconstitucionalidade:

I - o Presidente da República;

II - a Mesa do Senado Federal;

III - a Mesa da Câmara dos Deputados;

IV - a Mesa de Assembleia Legislativa ou a Mesa da Câmara Legislativa do Distrito Federal;

V - o Governador de Estado ou o Governador do Distrito Federal;

VI - o Procurador-Geral da República;

VII - o Conselho Federal da Ordem dos Advogados do Brasil;

VIII - partido político com representação no Congresso Nacional;

IX - confederação sindical ou entidade de classe de âmbito nacional.

Parágrafo único. As entidades referidas no inciso IX, inclusive as federações sindicais de âmbito nacional, deverão demonstrar que a pretensão por elas

\footnotetext{
${ }^{281}$ Gilmar Ferreira Mendes lembra que antes mesmo da atual Constituição Federal tal forma de ação já era admitida, embora não fosse formalmente prevista, já que a representação de inconstitucionalidade era entendida como de caráter ambivalente. (Jurisdição Constitucional: O controle abstrato de normas no Brasil e na Alemanha, pp.91-94)
} 
deduzida tem pertinência direta com os seus objetivos institucionais (VETADO)"

Como se vê, o artigo incluiu entre os legitimados para propor a ADI a Mesa da Câmara Legislativa do Distrito Federal e o Governador do Distrito Federal. Ambos já eram admitidos pela jurisprudência do $\mathrm{STF}^{282}$, que entendia que estavam entre os legitimados, já que o texto constitucional atribuiu ao Distrito Federal as mesmas competências relativas aos Estados ${ }^{283}$, embora o artigo 103 da Constituição não fizesse menção expressa $^{284}$, autorizando apenas a Mesa de Assembleia Legislativa e o Governador de Estado.

O páragrafo único, por sua vez, foi vetado em razão da jurisprudência do Tribunal que, à época, não admitia mais as federações sindicais de âmbito nacional entre os legitimados do inciso $\mathrm{IX}^{285}$, como será visto posteriormente, ao se analisar a definição de cada legitimado ${ }^{286}$. Apesar do veto ao parágrafo inteiro, nem todas as suas disposições ficaram comprometidas, como se explica nas razões do veto:

"É verdade que a oposição do veto à disposição contida no parágrafo único importará na eliminação do texto na parte em que determina que a confederação sindical ou entidade de classe de âmbito nacional (art. $2^{\underline{0}}$, IX) deverá demonstrar que a pretensão por elas deduzidas tem pertinência direta com os seus objetivos institucionais. Essa eventual lacuna será, certamente, colmatada pela jurisprudência do Supremo Tribunal Federal, haja vista que tal restrição já foi estabelecida em precedentes daquela Corte (cf., entre outros, ADIn-MC 1464, Rel.: Min. Moreira Alves; ADIn-MC 1103, Rel.:

\footnotetext{
${ }^{282}$ Ver Anna Candida da Cunha Ferraz, "O acesso à Jurisdição Constitucional como caminho para a sua democratização”, p.494; Gustavo Binenbojm, A nova Jurisdição Constitucional brasileira: legitimidade democrática e instrumentos de realização, p.141-143.

${ }^{283}$ Conforme art. 32 , par. $1^{\circ}$ da CF.

${ }^{284}$ Quanto à constitucionalidade dessa inovação da Lei 9.868/99, ver Manoel Gonçalves Ferreira Filho, Aspectos do Direito Constitucional Contemporâneo, pp.231-232; Anna Candida da Cunha Ferraz, Op. cit., p.494.

${ }^{285}$ Conforme razões do veto disponíveis em http://www.planalto.gov.br/ccivil_03/leis/Mensagem_Veto/1999/Mv1674-99.htm . ${ }^{286}$ Ver pp. 123 e seguintes.
} 
Min. Néri da Silveira, Rel. Acórdão Min. Maurício Corrêa; ADIn-MC 1519, Rel.: Min. Carlos Velloso).,"287

Ainda em 1999, a Lei 9.882 passou a regulamentar a arguição de descumprimento de preceito fundamental, instituindo como legitimados a propô-la aqueles designados para ingressar com a ação direta de inconstitucionalidade, mencionados anteriormente:

“Art. $2^{\text {o }}$ Podem propor arguição de descumprimento de preceito fundamental:

I - os legitimados para a ação direta de inconstitucionalidade;

II - qualquer pessoa lesada ou ameaçada por ato do Poder Público.(VETADO)

$\S 1^{\mathrm{o}} \mathrm{Na}$ hipótese do inciso II, faculta-se ao interessado, mediante representação, solicitar a propositura de arguição de descumprimento de preceito fundamental ao Procurador-Geral da República, que, examinando os fundamentos jurídicos do pedido, decidirá do cabimento do seu ingresso em juízo.

$\S 2^{\underline{0}}$ Contra o indeferimento do pedido, caberá representação ao Supremo Tribunal Federal, no prazo de cinco dias, que será processada e julgada na forma estabelecida no Regimento Interno do Supremo Tribunal Federal. (VETADO)"

O segundo inciso do artigo acima transcrito, que confere legitimação universal à ação, foi vetado pela Presidência da República sob o seguinte argumento:

"A disposição insere um mecanismo de acesso direto, irrestrito e individual ao Supremo Tribunal Federal sob a alegação de descumprimento de preceito fundamental por 'qualquer pessoa lesada ou ameaçada por ato do Poder Público'. A admissão de um acesso individual e irrestrito é incompatível com o controle concentrado de legitimidade dos atos estatais modalidade em que se insere o instituto regulado pelo projeto de lei sob exame. A inexistência de qualquer requisito específico a ser ostentado pelo proponente da arguição e a generalidade do objeto da impugnação fazem presumir a elevação excessiva do número de feitos a reclamar apreciação

\footnotetext{
287 A questão da pertinência temática aqui mencionada será tratada junto com os requisitos de admissibilidade dos legitimados, no item seguinte deste capítulo.
} 
pelo Supremo Tribunal Federal, sem a correlata exigência de relevância social e consistência jurídica das argüições propostas. Dúvida não há de que a viabilidade funcional do Supremo Tribunal Federal consubstancia um objetivo ou princípio implícito da ordem constitucional, para cuja máxima eficácia devem zelar os demais poderes e as normas infraconstitucionais. De resto, o amplo rol de entes legitimados para a promoção do controle abstrato de normas inscrito no art. 103 da Constituição Federal assegura a veiculação e a seleção qualificada das questões constitucionais de maior relevância e consistência, atuando como verdadeiros agentes de representação social e de assistência à cidadania. Cabe igualmente ao Procurador-Geral da República, em sua função precípua de Advogado da Constituição, a formalização das questões constitucionais carentes de decisão e socialmente relevantes. Afigura-se correto supor, portanto, que a existência de uma pluralidade de entes social e juridicamente legitimados para a promoção de controle de constitucionalidade - sem prejuízo do acesso individual ao controle difuso torna desnecessário e pouco eficiente admitir-se o excesso de feitos a processar e julgar certamente decorrentes de um acesso irrestrito e individual ao Supremo Tribunal Federal. Na medida em que se multiplicam os feitos a examinar sem que se assegure sua relevância e transcendência social, o comprometimento adicional da capacidade funcional do Supremo Tribunal Federal constitui inequívoca ofensa ao interesse público. Impõe-se, portanto, seja vetada a disposição em comento." (Grifamos)

Quantos aos parágrafos do artigo $2^{\circ}$, viu-se que o primeiro foi mantido, embora se refira a inciso que foi vetado. Nele consta a possibilidade de qualquer pessoa lesada ou ameaçada de lesão por ato do Poder Público recorrer ao Ministério Público para que o Procurador-Geral da República, analisando os fundamentos jurídicos e entendendo cabível, ingressará com a arguição.

Já o parágrafo $2^{\circ}$, que previa a possibilidade de representação ao STF em caso de indeferimento do pedido pelo Procurador-Geral, foi vetado. Os argumentos utilizados para o veto realçaram a importância do juízo prévio feito pelo Procurador-Geral, na sobrecarga que a análise de tais recursos traria ao Tribunal, na inexistência de direito 
subjetivo a um acesso imediato à Corte e na existência de outras vias para o processo e julgamento das controvérsias constitucionais existentes ${ }^{288}$.

Com a Emenda Constitucional n ${ }^{\circ}$ 45, de 30 de dezembro de 2004, a legitimação da ação declaratória de constitucionalidade foi igualada à da ação direta de inconstitucionalidade, além de terem sido incluídos no rol do artigo 103 a Câmara Legislativa do Distrito Federal e o Governador do Distrito Federal, que, como visto, já integravam o rol de legitimados a propor ação direta de inconstitucionalidade e ação declaratória de constitucionalidade pela Lei 9.868/99, art. $2^{\circ}$, IV e V, e antes mesmo já eram admitidos como propositores pelo STF.

Com a Lei 12.063, de 27 de outubro de 2009, alterou-se a Lei 9.868/99 para a inclusão de artigos que disciplinam a ação direta de inconstitucionalidade por omissão, trazendo a seguinte previsão quanto a quem pode ingressar com tal ação:

“Art. 12-A. Podem propor a ação direta de inconstitucionalidade por omissão os legitimados à propositura da ação direta de inconstitucionalidade e da ação declaratória de constitucionalidade."

Pelo exposto, vê-se que embora a atual redação do artigo 103 da Constituição Federal refira-se apenas à ação direta de inconstitucionalidade e à ação declaratória de constitucionalidade, o rol nele previsto também se aplica à ação direta de inconstitucionalidade por omissão, e à arguição de descumprimento de preceito fundamental.

“Art. 103. Podem propor a ação direta de inconstitucionalidade e a ação declaratória de constitucionalidade:

I - o Presidente da República;

II - a Mesa do Senado Federal;

III - a Mesa da Câmara dos Deputados;

IV - a Mesa de Assembleia Legislativa ou da Câmara Legislativa do Distrito Federal;

${ }^{288}$ Ver as razões do veto, disponíveis em http://www.planalto.gov.br/ccivil_03/Leis/Mensagem_Veto/1999/Mv1807-99.htm . 
V - o Governador de Estado ou do Distrito Federal;

VI - o Procurador-Geral da República;

VII - o Conselho Federal da Ordem dos Advogados do Brasil;

VIII - partido político com representação no Congresso Nacional;

IX - confederação sindical ou entidade de classe de âmbito nacional.”

Se pela lei e pela Constituição Federal são esses os únicos dispositivos que tratam dos legitimados e da propositura das ações do controle concentrado de constitucionalidade, o Regimento Interno do Tribunal dedica um único artigo ao tema, e refere-se a apenas um dos legitimados:

“Art. 169. O Procurador-Geral da República poderá submeter ao Tribunal, mediante

representação, o exame de lei ou ato normativo federal ou estadual, para que seja declarada a sua inconstitucionalidade.

$\S 1^{\circ}$ Proposta a representação, não se admitirá desistência, ainda que afinal o Procurador-Geral se manifeste pela sua improcedência.

$\S 2^{\circ}$ Não se admitirá assistência a qualquer das partes."

A referência apenas ao Procurador-Geral e ao termo "representação" evidencia que o referido artigo é anterior às modificações da Constituição Federal de 1988. De fato, a redação do caput é de 1980 e a dos parágrafos advém de reforma regimental de 1985. Apesar disso e da expansão do rol de legitimados após elaboração do artigo, suas disposições ainda são válidas: ao Procurador-Geral da República, um dos legitimados a provocar o controle concentrado de constitucionalidade, é vedada a desistência após a propositura da ação, podendo ele, porém, se manifestar pela sua improcedência.

Assim, são esses os únicos dispositivos normativos sobre a matéria. Como se verá, muito acerca do tema, em especial com relação aos requisitos para admissibilidade dos legitimados, teve origem na construção jurisprudencial. 


\subsection{Quem são os legitimados}

Como visto, atualmente são legitimados para propor ação direta de inconstitucionalidade, ação declaratória de constitucionalidade, ação direta de inconstitucionalidade por omissão e arguição de descumprimento de preceito fundamental os seguintes atores: o Presidente da República; a Mesa do Senado Federal; a Mesa da Câmara dos Deputados; a Mesa de Assembleia Legislativa ou da Câmara Legislativa do Distrito Federal; o Governador de Estado ou do Distrito Federal; o Procurador-Geral da República; o Conselho Federal da Ordem dos Advogados do Brasil; partido político com representação no Congresso Nacional; confederação sindical ou entidade de classe de âmbito nacional.

O maior acesso ao Tribunal, possibilitado em grande parte em razão dessa expansão do rol de legitimados, levou a um considerável aumento da quantidade de ações ajuizadas perante o Supremo Tribunal Federal ${ }^{289}$. A fim de evitar que isso comprometa seus trabalhos, a Corte tem limitado o acesso através da interpretação restritiva dos legitimados e da criação de requisitos ${ }^{290}$ de admissibilidade para alguns deles.

Como constatam Fernanda Dias Menezes de Almeida e Anna Candida da Cunha Ferraz, "na via interpretativa a democratização do acesso à jurisdição concentrada acabou sofrendo rigorosa redução, sob vários aspectos",291.

Logo, para saber quem de fato pode ingressar com as ações de controle concentrado de constitucionalidade, não basta recorrer ao rol do artigo 103 da Constituição. Faz-se necessária uma análise minuciosa de cada um dos elencados, recorrendo-se especialmente à jurisprudência, para que se conheça o verdadeiro grau de abertura proporcionado.

\footnotetext{
${ }^{289}$ Apenas como exemplo, se antes de 1988 a média de ADIs ajuizadas por ano era de 33 ações, de 1988 até 2004 essa média chegou a 210 processos instaurados por ano. (Gilmar Ferreira Mendes, Jurisdição Constitucional: $O$ controle abstrato de normas no Brasil e na Alemanha, p. 81). Ver também Marcos Paulo Veríssimo, A judicialização dos conflitos de justiça distributiva no Brasil: O processo judicial no pós-1988, pp. 151-152.

${ }^{290}$ Importante ressaltar que os requisitos aqui mencionados referem-se aos de admissibilidade do legitimado, e não da petição inicial, que fogem ao escopo deste trabalho e, por isso, não serão analisados. ${ }^{291}$ Fernanda Dias Menezes de Almeida e Anna Candida da Cunha Ferraz, Op. cit., p.23.
} 
Um dos requisitos de admissibilidade criados jurisprudencialmente, entretanto, é aplicado não apenas a um dos legitimados, mas a um grupo deles, e, por essa razão, será estudado primeiramente. Trata-se da chamada pertinência temática.

\subsubsection{Pertinência temática}

Pertinência temática é "o nexo de afinidade entre os objetivos institucionais da entidade que ajuíza a ação e o conteúdo material da norma impugnada"292, conforme definição dada pelo próprio STF, e aproxima-se da ideia do direito processual de uma das condições da ação, o interesse em agir, segundo a doutrina ${ }^{293}$. Pelo entendimento da Corte, essa relação de pertinência faz-se presente ainda que a lei impugnada afete indiretamente os interesses da autora da ação e que o prejuízo que cause a seus objetivos seja apenas potencial ${ }^{294}$.

A observância desse nexo passou a ser exigida pelo Tribunal para que alguns dos legitimados do rol do artigo 103 da Constituição sejam de fato admitidos como tais. Ou seja, trata-se de um requisito de admissibilidade criado pela jurisprudência.

Devem atender tal requisito os ditos legitimados condicionados ${ }^{295}$ ou especiais ${ }^{296}$ : Governadores de Estados e Distrito Federal, Mesas de Assembleias Legislativas e da Câmara Legislativa Distrital, confederações sindicais e entidades de classe de âmbito nacional. Logo, esses só podem impugnar normas que guardem relação com suas finalidades institucionais. Não havendo essa relação, não podem propor ação ainda que com objetivo cívico ou altruísta, nem mesmo para agir supletivamente em caso de omissão dos legitimados que não se encontram nesse grupo ${ }^{297}$.

\footnotetext{
292 ADIn 1.096-4-RS, Rel. Min. Celso de Mello, RTJ 158:443.

293 Nesse sentido, Luís Roberto Barroso, Op. cit., p.168; Gilmar Ferreira Mendes, Jurisdição Constitucional: $O$ controle abstrato de normas no Brasil e na Alemanha, p.174.

${ }^{294}$ Ver Luiz Vicente de Medeiros Queiroz Neto, Op. cit., pp.10-11.

295 Nomenclatura adotada por Gustavo Binenbojm, A nova Jurisdição Constitucional brasileira: legitimidade democrática e instrumentos de realização, p.145.

${ }^{296}$ É essa a classificação utilizada por Luiz Vicente de Medeiros Queiroz Neto, Op. cit., p.7; Luís Roberto Barroso, Op.cit., p.161.

${ }^{297}$ Luiz Vicente de Medeiros Queiroz Neto, Op. cit., p.11.
} 
Atualmente, porém, o STF tem flexibilizado seu entendimento, não julgando mais necessária a demonstração da pertinência temática do autor com todos os dispositivos impugnados.

Assim ocorreu na ADI 4364, proposta pela Confederação Nacional do Comércio de Bens, Serviços e Turismo para impugnar lei do Estado de Santa Catarina que instituiu quatro faixas de pisos salariais, conforme a atividade exercida, para os trabalhadores daquele Estado - pisos que deveriam ser respeitados, portanto, pelos empregadores representados pelo sindicato. Entendeu a autora que tal determinação violaria o princípio da isonomia, além dos artigos $7^{\circ}, \mathrm{V}, 8^{\circ}$, I e $114, \S 2^{\circ}$ da Constituição Federal.

Em decisão, assim o Ministro Dias Toffoli explicou o novo entendimento do $\mathrm{STF}^{298}$ :

"Nesse sentido, no julgamento da medida cautelar na ADI n 2.403/RJ, também de autoria da CNC (Confederação Nacional do Comércio de Bens, Serviços e Turismo), que impugnava a Lei $\mathrm{n}^{\circ} 3.512$, de 2000, do Estado do Rio de Janeiro, a qual, assim como no presente caso, instituía pisos salariais, este Supremo Tribunal Federal, por maioria de votos, conheceu parcialmente da ação direta, deixando de fazê-lo em relação aos incisos II e III do art. $1^{\circ}$ da lei questionada, uma vez que as profissões mencionadas não se relacionavam com o comércio (Relator o Ministro Nelson Jobim, DJ de 2/4/04).

Contudo, entendo que esse entendimento não mais deve ser aplicado à presente hipótese. Há casos que não admitem soluções parciais, dada a natureza da norma ou mesmo da inconstitucionalidade que a vicia.

A meu ver, a exigência de pertinência temática não impede, quando o vício de inconstitucionalidade for idêntico para todos os seus destinatários, o amplo conhecimento da ação, nem a declaração de inconstitucionalidade da norma, para além do âmbito dos indivíduos representados pela entidade requerente."299 (Grifamos)

\footnotetext{
${ }^{298}$ No mesmo sentido, ver ADI 15, ADI 3710, ADI 4375, etc.

${ }^{299}$ Ver seção Acompanhamento Processual, no site do STF.
} 
Quanto aos demais legitimados, denominados de universais ${ }^{300}$, plenos ou incondicionados $^{301}$, não há a necessidade de demonstrarem a existência de relação entre seus objetivos e interesses e a norma impugnada. Podem, portanto, impugnar qualquer lei ou ato normativo, independente do seu conteúdo material. São eles:o Presidente da República, a Mesa do Senado Federal, a Mesa da Câmara dos Deputados, o ProcuradorGeral da República, o Conselho Federal da Ordem dos Advogados do Brasil e o partido político com representação no Congresso Nacional.

As justificativas para essa divisão, que não é prevista no ordenamento jurídico brasileiro, variam conforme o legitimado.

Com relação às confederações sindicais e entidades de classe de âmbito nacional, entende-se que, por serem pessoas jurídicas de direito privado, elas não possuem interesse genérico na defesa da supremacia constitucional, mas apenas na defesa de seus interesses particulares ${ }^{302}$. Para que possam ingressar com ações de controle concentrado de constitucionalidade justifica-se, assim, a comprovação da pertinência de seus fins institucionais com o objeto da ação.

É esse o entendimento que se depreende, por exemplo, da decisão do Ministro Marco Aurélio na ADI 4721. A ação foi proposta pela Confederação Nacional dos Trabalhadores Metalúrgicos e impugnava artigos de leis do Estado do Espírito Santo que, segundo a autora, concediam benefício fiscal sem a prévia autorização por convênio interestadual, o que feriria o artigo $155, \S 2^{\circ}$, XII, g, da Constituição Federal.

A respeito da legitimidade dessa confederação sindical, assim se pronunciou o Ministro Relator:

“O artigo 103, inciso IX, da Carta Federal atribui às confederações sindicais a legitimidade para a deflagração do controle concentrado de constitucionalidade. Interpretando tal dispositivo, o Supremo assentou a necessidade de demonstrar não apenas a natureza jurídica exigida pela Lei

\footnotetext{
${ }^{300}$ Alexandre de Moraes, Op. cit., p.233; Carolina Cutrupi Ferreira, Op. cit., p.220; Luís Roberto Barroso, Op. cit., p.161.

${ }^{301}$ Gustavo Binenbojm, A Nova Jurisdição Constitucional Brasileira: Legitimidade democrática e instrumentos de realização, p.145.

${ }^{302}$ Luiz Vicente de Medeiros Queiroz Neto, Op. cit., p.12.
} 
Maior, mas também a relação de pertinência temática, que consiste no elo entre os objetivos sociais da confederação e o alcance da norma que se pretenda ver fulminada. Isso porque, ao contrário de outros legitimados, cuida-se de entidade de direito privado, vinculada essencialmente à proteção dos interesses da própria categoria representada. Precedentes: Ação Direta de Inconstitucionalidade $n^{\circ} 1.151 / \mathrm{MG}$, de minha relatoria, e Medida Cautelar na Ação Direta de Inconstitucionalidade $n^{\circ}$ 1.114/DF, relator Ministro Ilmar Galvão.

Embora a requerente busque revelar, na inicial, a pertinência temática, temse que o raciocínio desenvolvido acabaria por transmudar em abrangente a legitimação restrita aos interesses da categoria. É que a argumentação veiculada, considerado o que aponta como guerra fiscal, leva em conta a via indireta, ou seja, a diminuição de empregos. As normas impugnadas, concessivas de financiamentos em condições favorecidas para a importação e exportação de certos bens, não se dirigem especificamente aos metalúrgicos.

3. Ante o quadro, nego seguimento ao pedido."303 (Grifamos)

Por sua vez, a justificativa para a aplicação da pertinência temática para Governadores de Estados e Distrito Federal e Mesas de Assembleia Legislativa e da Câmara Legislativa Distrital é, naturalmente, diversa, já que são pessoas jurídicas de direito público. Ao restringir o acesso desses entes, o STF parece visar à manutenção da Federação e à autonomia de seus entes.

Assim, embora esses legitimados possam contestar livremente a constitucionalidade de qualquer norma local, para a impugnação de normas federais ou de normas originárias de outros Estados ou Distrito Federal devem provar que elas repercutem em sua esfera de autonomia ou que produzem efeitos negativos para o impugnante ${ }^{304}$.

Foi esse o entendimento adotado, por exemplo, na decisão do Ministro Celso de Mello na ADI 4635. Nessa ação, de autoria do Governador do Estado do Amazonas, foram

\footnotetext{
${ }^{303}$ Ver seção Acompanhamento Processual, no site do STF.

${ }^{304}$ Ver Luiz Vicente de Medeiros Queiroz Neto, Op. cit., pp.13-14.
} 
impugnados artigos de leis e decretos do Estado de São Paulo por entender que tais dispositivos criavam incentivos fiscais aos produtos paulistas, ferindo assim os artigos 152 e 155, § 2. ${ }^{\circ}$, XII, g, da Constituição Federal, além de artigos do Ato das Disposições Constitucionais Transitórias que asseguram proteção especial à Zona Franca de Manaus.

A respeito da legitimidade do autor, assim se posicionou o Ministro Relator:

"De outro lado, verifico restar configurado, na espécie, o requisito da pertinência temática, que se caracteriza pela existência do nexo de afinidade entre o dever de proteção que incumbe, no plano institucional, ao Governador do Estado do Amazonas, na preservação dos interesses dessa unidade da Federação, de um lado, e o conteúdo material dos dispositivos por ele impugnados na presente sede processual. Com efeito, existe, no caso, esse nexo de pertinência temática, eis que o conteúdo dos atos normativos ora questionados - que versam a concessão, pelo Estado de São Paulo, de benefícios fiscais pertinentes ao ICMS - relaciona-se, de modo direto, com o interesse do Estado do Amazonas, eis que, como explicitado pela douta Procuradoria-Geral da República, 'No caso ora em exame, o requisito é satisfeito pelo simples fato de que a concessão de benefícios fiscais do ICMS, sem a prévia celebração de convênio no âmbito do Confaz, é capaz de causar impactos na economia dos demais Estado da Federação'., 305 (Grifamos)

Já com relação aos legitimados universais, a pertinência temática não é aplicada já que as situações acima descritas, que justificam seu uso, não se verificam quanto a eles.

Assim, diferentemente das confederações sindicais e entidades de classe de âmbito nacional, todos aqueles definidos como legitimados universais são pessoas jurídicas de direito público de modo que, em tese, não defendem interesses particulares e não precisam demonstrar interesse genérico na defesa da Constituição Federal. Por outro lado, ao contrário dos Governadores de Estados ou Distrito Federal, das Mesas de Assembleia Legislativa e da Câmara Legislativa Distrital, nenhum dos legitimados

${ }^{305}$ Ver seção Acompanhamento Processual, no site do STF. 
universais representa ente federado, razão pela qual sua manifestação em nada pode comprometer a unidade da Federação ou a autonomia de seus entes.

É importante ressaltar que a pertinência temática não é prevista por nenhuma norma em vigência. Embora, como visto ${ }^{306}$, houvesse a previsão de tal instituto no projeto da Lei 9.868/99 - mas apenas para confederações sindicais e entidades de classe de âmbito nacional -, o artigo que a instituia foi vetado pela Presidência da República.

Nas razões do veto afirmou-se que a ausência do referido artigo não comprometeria a aplicação desse requisito de admissibilidade já que, à época, a necessidade dessa relação de pertinência já era estabelecida pelos precedentes da Corte $^{307}$. De fato, a pertinência temática já era exigida para as entidades de classe de âmbito nacional (ADI 396, ADI 138), para as confederações sindicais (ADI 1114), bem como para o Chefe do Executivo estadual ou distrital e Mesa das Assembleias Legislativas dos Estados ou Mesa da Câmara Legislativa distrital (ADI 902).

Após essas breves considerações acerca desse requisito de admissibilidade, segue uma análise de como se dá a admissão de cada um dos legitimados pelo Supremo Tribunal Federal.

\subsubsection{A interpretação e admissão dos legitimados}

Além da pertinência temática, requisito de admissibilidade aplicado a mais de um legitimado, a Corte por vezes entende que existem outros requisitos, específicos para cada proponente, que devem ser observados para sua admissão. Embora os dispositivos legais não façam tal previsão, é assim que tem se manifestado a jurisprudência em relação a alguns dos legitimados.

\footnotetext{
${ }^{306}$ Ver pp.111 e seguintes.

${ }^{307}$ Sobre o curioso posicionamento da Presidência da República no veto, adequando a lei ao entendimento do STF, ver Gustavo Binebojm, A Nova Jurisdição Constitucional Brasileira: legitimidade democrática e instrumentos de democratização, p.147.
} 
Para uma completa análise do tema, será estudada como se dá a admissão de cada um dos legitimados, separadamente, seguindo a ordem utilizada pelo artigo 103 da Constituição Federal.

a) Presidente da República

O Presidente da República figura entre os legitimados universais, podendo, a princípio, ingressar com ação que impugne a inconstitucionalidade de qualquer norma. A discussão ocorre quando o ato normativo contestado tenha sido por ele mesmo sancionado. Se o Presidente não exerceu seu poder de veto, poderá, posteriormente, arguir a inconstitucionalidade da lei?

A doutrina parece unânime ao defender essa possibilidade ${ }^{308}$, já que os legitimados atuam como defensores da ordem constitucional, e se o Presidente "sanciona, por equívoco ou inadvertência, projeto de lei juridicamente viciado, não está ele compelido a persistir no erro, sob pena de, em homenagem a uma suposta coerência, agravar o desrespeito à Constituição"309. Além disso, pode ocorrer do ato normativo ser sancionado pelo Presidente da República e impugnado, posteriormente, quando o cargo já tiver sido assumido por outra pessoa, devendo ser reconhecida, igualmente, sua legitimidade.

Em defesa do reconhecimento da legitimidade nessas situações, argumenta Gustavo Binenbojm que "a legitimidade desses órgãos (Chefes do Poder Executivo legitimados pela Constituição) para o ajuizamento da ação não é condicionada de nenhuma forma pela Constituição" e, assim, "não caberia ao intérprete e aplicador da Constituição restringir o que não foi objeto de restrição por parte do legislador constituinte" 310 .

Embora o argumento seja indubitavelmente correto, não parece ter muito peso para o Supremo Tribunal Federal, já que o texto constitucional não faz restrição alguma a qualquer dos legitimados, mas, como se vê neste capítulo, a Corte faz.

\footnotetext{
${ }^{308}$ Nesse sentido, Gilmar Ferreira Mendes, Jurisdição Constitucional: O controle abstrato de normas no Brasil e na Alemanha, pp.160-161; Luís Roberto Barroso, Op. cit., pp.161-162; Gustavo Binenbojm, A nova Jurisdição Constitucional brasileira: legitimidade democrática e instrumentos de realização, pp.158-160; entre outros.

${ }^{309}$ Gilmar Ferreira Mendes, Op. cit., p.160.

${ }^{310}$ Gustavo Binenbojm, Op. cit., pp. 158-159.
} 
Se a doutrina assim se manifesta, não há como saber qual o entendimento do STF, que ainda não enfrentou essa situação ${ }^{311}$. Entretanto, em decisão referente a Governador de Estado - e que, analogicamente, aplica-se ao Presidente da República - entendeu o Tribunal que quando o ato normativo por ele sancionado for impugnado por outro legitimado, o Chefe do Poder Executivo deverá figurar "no pólo passivo da relação processual", não podendo ingressar na causa na qualidade de litisconsorte ativo do autor da impugnação ${ }^{312}$.

As críticas a esse entendimento vão no seguinte sentido:

“A solução da Suprema Corte para o caso, data venia, não soa coerente. Com efeito, quem pode o mais pode o menos. Assim, se o Chefe do Executivo pode intentar a ação direta, como seu autor único e autônomo, não parece razoável que lhe seja defeso reconhecer a procedência do pedido formulado por outro ente legitimado."

b) Mesa do Senado Federal e Mesa da Câmara dos Deputados

Também figuram entre os legitimados universais a Mesa do Senado Federal e a Mesa da Câmara dos Deputados. Cabe, de início, ressaltar que não se trata aqui da Mesa do Congresso Nacional, formada por membros da Mesa de suas duas Casas e não prevista pelo texto constitucional entre os legitimados.

\footnotetext{
${ }^{311}$ Em verdade, o Presidente da República figura entre os legitimidos que menos demandaram o STF, conforme dados da Sociedade Brasileira de Direito Público, Op. cit., p.66 e de Eloísa Machado de Almeida, Op. cit., p.29.

312 Assim foi decidido na ADI 807, Relator Min. Celso de Mello, DJ, 11 jun. 1993. Vale destacar que, nessa questão, quem assume o pólo processual é o Chefe do Poder Executivo Estadual ou Federal, logo, é representado por quem exerce o cargo no momento, sendo irrelevante o fato de não ser a mesma pessoa que exercia o cargo quando da sanção da lei impugnada. No caso em análise, por exemplo, no momento da ratificação da lei impugnada quem exercia o cargo de Governador do Estado do Rio Grande do Sul era Sinval Guazzelli, já entre a propositura da ADI e a referida decisão do STF, era Alceu de Deus Collares o Governador do Estado.

${ }^{313}$ Gustavo Binenbojm, A nova Jurisdição Constitucional brasileira: legitimidade democrática e instrumentos de realização, p.160. Na mesma linha de raciocínio, Gilmar Ferreira Mendes, Jurisdição Constitucional: O controle abstrato de normas no Brasil e na Alemanha, pp.161-162.
} 
Assim como o Presidente da República, podem impugnar atos normativos aos quais deram origem e raramente se utilizam das ações de controle concentrado de constitucionalidade ${ }^{314}$.

c) Mesa de Assembleia Legislativa ou da Câmara Legislativa do Distrito Federal

Mais restrita, porém, é a atuação da Mesa de Assembleia Legislativa ou da Câmara Legislativa do Distrito Federal. Como visto, elas figuram entre os legitimados especiais, devendo provar a existência de pertinência temática.

Podem, portanto, impugnar livremente apenas atos normativos locais, devendo, para contestarem normas federais ou de outros Estados ou Distrito Federal, demonstrar que elas repercutem e atingem de forma negativa sua esfera de autonomia. A ação pode ter por objeto ato normativo emanado do próprio Poder por ela integrado.

d) Governador de Estado ou do Distrito Federal

A mesma relação de pertinência deve demonstrar o Governador de Estado ou do Distrito Federal para ser admitido como legitimado: a norma impugnada pode ser originária do seu Estado, da União ou de outros Estados se "interferirem ilegitimamente com competências ou interesses juridicamente protegidos de seu Estado"315.

Aqui cabem os comentários feitos ao tratar da legitimidade do Presidente da República $^{316}$ acerca da possibilidade de impugnar normas por ele sancionadas e de figurar como litisconsórcio ativo nesses casos. Vale notar que, segundo dados do próprio STF, os Governadores de Estados e do Distrito Federal foram responsáveis por mais de $25 \%$ de todas as ADIs propostas entre 1998 e $2005^{317}$.

e) Procurador-Geral da República

Figura ainda entre os legitimados o Procurador-Geral da República, que antes da Constituição de 1988 detinha o monopólio na propositura desse tipo de ação. Não é feita

\footnotetext{
314 Junto com o Presidente da República, estão entre os que menos demandam o STF (Sociedade Brasileira de Direito Público, Op. cit., p.66).

${ }^{315}$ Luís Roberto Barroso, Op. cit., p.164.

${ }^{316}$ Ver pp.124-125.

${ }^{317}$ Dados disponíveis em Eloísa Machado de Almeida, Op. cit., p.29.
} 
qualquer restrição quanto à sua atuação, estando entre os legitimados universais que mais demandam o Supremo Tribunal Federal ${ }^{318}$.

\section{f) Conselho Federal da Ordem dos Advogados do Brasil}

Logo em seguida, no rol do artigo 103 da Constituição Federal, consta como legitimado o Conselho Federal da Ordem dos Advogados do Brasil. Em razão de sua atuação decisiva no processo de redemocratização do país ${ }^{319}$, a OAB não foi compreendida nem como entidade de classe de âmbito nacional, prevista em inciso diverso, nem como entidade de fiscalização profissional, cuja legitimidade não é reconhecida pelo $\mathrm{STF}^{320}$.

O tratamento diferenciado conferido ao órgão representativo dos advogados é evidente, não sendo exigida dele a observância de qualquer requisito de admissibilidade, nem mesmo de pertinência temática. Logo, o Conselho Federal da OAB figura entre os legitimados universais, podendo impugnar qualquer ato normativo.

\section{g) Partido político com representação no Congresso Nacional}

Igualmente irrestrita é a admissão de partido político com representação no Congresso Nacional como legitimado a propor ação de controle concentrado de constitucionalidade. Como legitimado universal, podendo impugnar qualquer ato normativo, foi quem mais acionou o $\mathrm{STF}^{321}$.

A única limitação vem expressa no próprio inciso do artigo 103 da Constituição: o partido político deve ter representação no Congresso Nacional. Essa exigência, no entanto, não restringe de fato a legitimação, já que basta uma representação singular.

\footnotetext{
${ }^{318}$ Conforme dados da Sociedade Brasileira de Direito Público, Op. cit., p.66, figura logo depois dos partidos políticos entre os legitimados universais que mais demandam. Já pelas informações obtidas por Eloísa Machado de Almeida, Op. cit., p.29, é responsável por 22\% de todas as ADIs propostas de 1988 até 2005.

${ }^{319}$ Assim entende, por exemplo, Luís Roberto Barroso (Op. cit., p.162). Vale lembrar, porém, que outras entidades e sindicatos foram de extrema importância para o processo de democratização e nem por isso possuem legitimidade ativa irrestrita, como a Constituição Federal conferiu à OAB.

320 "Os Conselhos são entidades de fiscalização profissional, não autônomas, inseridas no Poder Executivo, com competências administrativas e submetidas ao controle ou supervisão de órgão da administração direta - o Ministério - que também não possui a legitimidade pretendida. Para o Tribunal, não são entidades de classe e por tal razão não deteriam a legitimidade ativa ad causam para o controle abstrato de constitucionalidade. O Conselho Federal da Ordem dos Advogados do Brasil, todavia, tem reconhecimento expresso no Art. 103, CF." (Carolina Cutrupi Ferreira, Op. cit., pp.32-33)

${ }^{321}$ Conforme dados da Sociedade Brasileira de Direito Público, Op. cit., p.66 e Luís Roberto Barroso, Op. cit., p.163.
} 
Atualmente, entende o STF que, para que esse requisito seja observado, deve estar presente no momento da propositura da ação, sendo irrelevante para o seu prosseguimento a ulterior perda de representação do partido ${ }^{322}$.

h) Confederação sindical

Muito mais complexo é o processo de admissão de outros dois legitimados relacionados à sociedade civil: a confederação sindical e a entidade de classe de âmbito nacional. Curiosamente, esses legitimados respondem, juntos, por mais de $40 \%$ das ações de controle concentrado de constitucionalidade propostas perante o Supremo Tribunal Federal $^{323}$.

As confederações sindicais são entidades que representam sindicatos ou federações de sindicatos, sendo previstas pela Constituição Federal ${ }^{324}$ e regulamentadas pelo artigo 535 da CLT:

“Art. 535 - As Confederações organizar-se-ão com o mínimo de 3 (três) federações e terão sede na Capital da República.

$\S 1^{\mathrm{o}}$ - As confederações formadas por federações de Sindicatos de empregadores denominar-se-ão: Confederação Nacional da Indústria, Confederação Nacional do Comércio, Confederação Nacional de Transportes Marítimos, Fluviais e Aéreos, Confederação Nacional de Transportes Terrestres, Confederação Nacional de Comunicações e Publicidade, Confederação Nacional das Empresas de Crédito e Confederação Nacional de Educação e Cultura.

$\S 2^{\circ}$ - As confederações formadas por federações de Sindicatos de empregados terão a denominação de: Confederação Nacional dos Trabalhadores na Indústria, Confederação Nacional dos Trabalhadores no Comércio, Confederação Nacional dos Trabalhadores em Transportes Marítimos, Fluviais e Aéreos, Confederação Nacional dos Trabalhadores em Transportes Terrestres, Confederação Nacional dos Trabalhadores em Comunicações e Publicidade, Confederação Nacional dos Trabalhadores nas

\footnotetext{
${ }^{322}$ Ver ADIs 2159 e 2618, ambas de Relatoria do Ministro Carlos Velloso.

${ }^{323}$ Conforme dados disponíveis em estudo da Sociedade Brasileira de Direito Público, ingressam com $44,7 \%$ dos atos normativos oriundos do Poder Legislativo e 41,3\% daqueles com origem no Poder Executivo. (Op. cit., p.66)

324،Art. $8^{\circ}$ É livre a associação profissional ou sindical, observado o seguinte: (...) IV - a Assembleia geral fixará a contribuição que, em se tratando de categoria profissional, será descontada em folha, para custeio do sistema confederativo da representação sindical respectiva, independentemente da contribuição prevista em lei;"
} 
Empresas de Crédito e Confederação Nacional dos Trabalhadores em Estabelecimentos de Educação e Cultura.

$\S 3^{\circ}$ - Denominar-se-á Confederação Nacional das Profissões Liberais a reunião das respectivas federações.

$\S 4^{\circ}$ - As associações sindicais de grau superior da Agricultura e Pecuária serão organizadas na conformidade do que dispuser a lei que regular a sindicalização dessas atividades ou profissões." (Grifamos)

Em razão das disposições do caput do artigo supracitado, portanto, o STF entendeu como requisitos para o reconhecimento da confederação ela ser composta por no mínimo três federações e ter sede no Distrito Federal.

Tais exigências foram afirmadas a partir da ADI 505, proposta pela Confederação Nacional dos Empregados nas Empresas de Geração, Transmissão e Distribuição de Eletricidade para arguir a inconstitucionalidade da Lei 8.030/90 e da Medida Provisória 154, do mesmo ano, por ferirem direito adquirido dos trabalhadores de terem suas remunerações corrigidas conforme índice previsto em lei anterior.

Assim se pronunciou o STF:

"Já firmou essa Corte o entendimento de que, das entidades sindicais, apenas as Confederações sindicais (art. 103, IX, da Constituição Federal) têm legitimação para propor ação direta de inconstitucionalidade.

Por outro lado, foi recebido pela Carta Magna vigente o artigo 535 da C.L.T. que dispõe sobre a estrutura das Confederações sindicais, exigindo, inclusive, que se organizem com um mínimo de três federações.

Ora, no caso, como se verifica, em face dos documentos a fls. 6 a 8 e 16, a Confederação em causa é constituída de uma Federação (a Federação dos Empregados nas Empresas de Geração, Transmissão e Distribuição de Eletricidade no Estado de São Paulo) e de quatro sindicatos desses trabalhadores situados nos Estados da Paraíba, Rio Grande do Norte, de Mato Grosso do Sul e de Sergipe. 
Já por isso se vê que não preenche a autora os requisitos legais necessários para que possa ser considerada uma Confederação sindical.",325

Em razão dessa interpretação, as Federações, que chegaram a ser reconhecidas como legitimadas pelo $\mathrm{STF}^{326}$, atualmente não têm legitimação reconhecida, já que como entidades de grau superior integradas por sindicatos, não preenchem os requisitos legais para constituir uma confederação sindical.

Logo, apenas se observadas as características do caput do art.535 da CLT, há de se falar em confederação. Mas não são apenas esses os requisitos que devem ser preenchidos para o reconhecimento, pelo Supremo Tribunal Fedral, de sua legitimidade.

Como visto, a confederação sindical inclui-se entre os legitimados especiais, devendo, portanto, demonstrar a existência de pertinência entre suas finalidades institucionais e a norma impugnada. Foi a partir da decisão da ADI 1114, em 1994, que a pertinência temática passou a ser exigida para esse legitimado.

A adoção de mais esse requisito, não previsto no ordenamento jurídico, fez com que muitas entidades alterassem seus estatutos a fim de se adequar às exigências do STF. Em razão de tais alterações, o Tribunal passou a exigir, além dos requisitos já mencionados, o registro da confederação no Ministério do Trabalho como prova da regularidade da entidade e das alterações estatutárias ${ }^{327}$.

i) Entidade de classe de âmbito nacional

Já as entidades de classe de âmbito nacional são vistas pelo STF como espécies "residuais" de legitimados ${ }^{328}$. Caso uma entidade não preencha os requisitos acima mencionados das confederações sindicais, o Tribunal verifica se ela preenche os requisitos para ser classificada como entidade de classe de âmbito nacional. É o que ocorre, por exemplo, com sindicatos e federações de sindicatos.

\footnotetext{
${ }^{325}$ Ver seção Acompanhamento Processual, no site do STF.

${ }^{326}$ ADI 209, Rel. Min. Sydney Sanches, DJ 07.03.91.

${ }^{327}$ Ver decisão da ADI 1565, de Relatoria do Ministro Néri da Fonseca.

${ }^{328}$ Carolina Cutrupi Ferreira, Op. cit., pp.27-28.
} 
Como visto, a lei não traz qualquer parâmetro para definir tais entidades, mas a jurisprudência encarregou-se de estabelecer critérios que devem ser observados para que sua legitimidade seja reconhecida.

O primeiro deles surge da expressão "âmbito nacional", presente no texto constitucional mas não especificada, nem mesmo em lei ou no Regimento Interno do STF.

Inicialmente, limitava-se o Tribunal a excluir do pólo ativo as associações estaduais, assim definidas em seus próprios estatutos ${ }^{329}$. Depois, passou-se a exigir que a representação nacional fosse efetiva, e não meramente formal, o que trouxe a necessidade de estipular critérios objetivos, que não foram previstos pelo legislador.

Foi assim que, no julgamento da ADI 386, o Ministro Moreira Alves, apoiando-se na Lei $5.682 / 71$, que à época disciplinava os partidos políticos ${ }^{330}$, definiu que para a verificação do âmbito nacional da entidade, ela deveria ter representatividade territorial em pelo menos um terço dos Estados da Federação.

Outro requisito para a admissão da entidade como legitimada é a exigência de que ela represente toda a categoria profissional ou econômica, e não apenas um segmento dela, e que todos seus filiados desempenhem a mesma atividade econômica ou profissional, sendo esse, o único tipo de vínculo entre os associados aceito pelo Tribunal. É esse o entendimento exposto nas ações a seguir comentadas.

A ADI 1788 foi proposta pela Associação Nacional dos Registradores de Pessoas Naturais para impugnar artigos da Lei 9.534/97 que determinavam a gratuidade do assento do registro civil de nascimento e de óbito, o que, na visão da autora, feriria os artigos $5^{\circ}$, LXXVI e 236 da Constituição Federal. A maioria do STF votou pela ilegitimidade ad causam da associação em razão do seguinte argumento:

“Associação Nacional dos Registradores de Pessoas Naturais não se compreende no âmbito do art. 103, IX, $2^{\mathrm{a}}$ parte, da Constituição Federal, por ser um subgrupo dentro do grupo representado pela ANOREG -

\footnotetext{
${ }^{329}$ Ver ADI 43, Rel. Min. Sydney Sanches, DJ 19.05.1989.

${ }^{330}$ A Lei 5.682/71, Lei Orgânica dos Partidos Políticos, foi revogada pela Lei 9.096/95, que manteve a exigência de apoio de eleitores distribuídos em pelo menos um terço dos Estados para o registro de estatuto de partido político de caráter nacional.
} 
Associação dos Notários e Registradores do Brasil. Assim, falta-lhe legitimidade para a propositura da presente ação. Ação direta de inconstitucionalidade não conhecida." ${ }^{331}$ (Grifamos)

Já a ADI 1693 foi proposta pela Associação Brasileira de Consumidores visando à declaração de inconstitucionalidade de atos normativos do Estado de Minas Gerais que teriam instituído tributo em benefício direto de algumas corporações privadas e outros órgãos e em desatendimento aos artigos 37 e 167, IV do texto constitucional, bem como ao princípio da igualdade.

Em votação unânime, o Tribunal entendeu pela ilegitimidade da associação, pelo motivo a seguir exposto:

"A cláusula constitucional sobre a legitimidade das entidades de classe de âmbito nacional para a propositura de ação direta de inconstitucionalidade pressupõe a representação de classe propriamente dita, a revelar interesses peculiares. A abrangência da representatividade da Associação Brasileira de Consumidores - e todos os cidadãos o são obstaculiza o enquadramento na previsão do inciso IX do artigo 103 da Carta Política da República.”,332 (Grifamos)

A respeito da necessidade da entidade representar a integralidade da categoria, porém, Luís Roberto Barroso alerta:

“A exigência deve ser interpretada com cautela, sob pena de produzir efeito inverso ao que se pretendia obter, privilegiando entidades caracterizadas por vínculo associativo excessivamente genérico e, por isso mesmo, menos aptas a representar de maneira efetiva os interesses de seus membros." ${ }^{333}$

Outro requisito exigido para o reconhecimento da entidade de classe como legitimada é a pertinência temática. Como visto, trata-se de legitimado especial, que deve demonstrar a relação da norma impugnada com seus interesses e objetivos.

\footnotetext{
${ }^{331}$ Ver seção Acompanhamento Processual, no site do STF.

${ }^{332}$ Ver seção Acompanhamento Processual, no site do STF.

${ }^{333}$ Luís Roberto Barroso, Op. cit., p.166.
} 
Por fim, vale lembrar que até 2004 o Supremo Tribunal Federal exigia que a entidade tivesse como membros apenas os próprios integrantes da classe, ou seja, pessoas físicas. Não era reconhecida, portanto, a legitimidade das "associações de associações", que congregam pessoas jurídicas, sindicatos ou entidades diversas. Apenas com o julgamento da ADI 3153, em 2004, a Corte mudou seu entendimento.

Tal ação foi proposta pela Federação Nacional das Associações dos Produtores de Cachaça de Alambique para impugnar artigo da Medida Provisória 2.189-49, de 23/08/2001, e outros atos normativos que agravavam o regime tributário da classe representada e, segundo a autora, ofenderiam os artigos 48, I e IV, 62, 170, IX e 179 da Constituição Federal.

Após decisão que negou trânsito à ação em razão de ilegitimidade ativa ad causam justamente por ser a autora uma "associação de associação", ilegítima diante do entendimento até então defendido pelo STF - foi interposto agravo, tendo a Corte mudado sua orientação, como se constata da análise da decisão a seguir:

“1. O conceito de entidade de classe é dado pelo objetivo institucional classista, pouco importando que a eles diretamente se filiem os membros da respectiva categoria social ou agremiações que os congreguem, com a mesma finalidade, em âmbito territorial mais restrito. 2. É entidade de classe de âmbito nacional - como tal legitimada à propositura da ação direta de inconstitucionalidade (CF, art 103, IX) - aquela na qual se congregam associações regionais correspondentes a cada unidade da Federação, a fim de perseguirem, em todo o País, o mesmo objetivo institucional de defesa dos interesses de uma determinada classe. 3. Nesse sentido, altera o Supremo Tribunal sua jurisprudência, de modo a admitir a legitimação das 'associações de associações de classe', de âmbito nacional, para a ação direta de inconstitucionalidade." 334 (Grifamos)

\subsection{Análise crítica}

\footnotetext{
${ }^{334}$ Ver seção Acompanhamento Processual, no site do STF.
} 
Vistos quem são os legitimados, de acordo com a Constituição Federal, e como eles são admitidos, conforme a jurisprudência do STF, resta agora uma análise crítica de todas as informações aqui referidas.

Inicialmente, cabe ressaltar que nenhum instrumento normativo traz restrições aos legitimados previstos constitucionalmente, logo, pela Constituição Federal, deve haver paridade de tratamento entre os legitimados. Todas as limitações a uma maior abertura da jurisdição constitucional concentrada, acima analisadas, foram acrescentadas unicamente pela interpretação do Supremo Tribunal Federal.

Como constata o relatório da Sociedade Brasileira de Direito Público, é "relevante frisar que é o próprio STF quem confere maior abertura ou restritividade no acesso ao controle concentrado de constitucionalidade, já que ele mesmo fixa os parâmetros e critérios para aferir a legitimidade de sindicatos, associações e entidades de classe (pertinência temática)" 335 .

Isso, por si só, merece críticas, já que "a falta de autorização constitucional para que o legislador estabeleça outras limitações ao direito de propositura suscita dúvida sobre a correção do entendimento esposado pelo Supremo Tribunal Federal"336.

Essa excessiva criação de requisitos para restringir o acesso ao Tribunal é responsável pelo fato da ilegitimidade ativa ad causam ser um dos principais motivos que levam à extinção sem julgamento de mérito das ações de controle concentrado de constitucionalidade ${ }^{337}$.

Como visto, entre os requisitos exigidos para a admissão de alguns legitimados está a pertinência temática. As críticas quanto a esse requisito são as de que, além de restringir a acessibilidade ao controle, ele ainda tende a transformar o processo de controle concentrado em processo subjetivo, de interesse das partes em litígio, alterando portanto a configuração do controle concentrado de constitucionalidade no país ${ }^{338}$.

\footnotetext{
${ }^{335}$ Sociedade Brasileira de Direito Público, Op. cit., p.26.

${ }^{336}$ Gilmar Ferreira Mendes, Jurisdição Constitucional: O controle abstrato de normas no Brasil e na Alemanha, p.172.

${ }^{337}$ Sociedade Brasileira de Direito Público, Op. cit., p.132.

338 Anna Candida da Cunha Ferraz, "O acesso à Jurisdição Constitucional como caminho para a sua democratização", p.495.
} 
Assim, sendo verdade que "a outorga do direito de propositura a diferentes órgãos estatais e a organizações sociais diversas ressalta o caráter objetivo do processo do controle abstrato de normas, uma vez que o autor não alega a existência de lesão a direitos, próprios ou alheios, atuando como representante do interesse público" ${ }^{339}$, é evidente que ao se exigir que alguns dos legitimados demonstrem o nexo entre seus interesses e a norma impugnada, ignora-se tal fato, alterando, com relação aos legitimados especiais, as características do processo. A exigência da pertinência temática é, portanto, absolutamente incompatível com a natureza objetiva do processo de controle abstrato de normas ${ }^{340}$.

Além disso, se a ideia do constituinte foi ampliar o rol de legitimados para permitir um maior acesso da sociedade à jurisdição constitucional, a criação de tal restrição, de constitucionalidade duvidosa, certamente prejudica essa tão esperada democratização.

Se a exigência da relação de pertinência para Governador de Estado ou do Distrito Federal e da Mesa de Assembleia Legislativa ou da Câmara Legislativa do Distrito Federal se justifica - vale lembrar, apesar de não haver previsão constitucional - para garantir a autonomia dos entes federados, para os demais legitimados especiais nem esse argumento pode ser sustentado.

A pertinência temática para as confederações sindicais e entidades de classe de âmbito nacional é aplicada, contrariando a Constituição Federal, única e exclusivamente para limitar a atuação dessas entidades e o elevado número de ações por elas propostas ${ }^{341}$. Sem nenhuma outra razão que possa justificar a necessidade de tal restrição, o Tribunal cria obstáculos ao único objetivo pretendido pelo constituinte ao prever tais entidades entre os legitimados: possibilitar à sociedade civil o acesso à jurisdição constitucional concentrada $^{342}$.

\footnotetext{
${ }^{339}$ Gilmar Ferreira Mendes, Jurisdição Constitucional: O controle abstrato de normas no Brasil e na Alemanha, p.157.

${ }^{340}$ Luiz Vicente de Medeiros Queiroz Neto, Op. cit., pp.16-17.

${ }^{341}$ Luís Roberto Barroso, Op. cit., p.169.

${ }^{342}$ Não há como negar que, dentre os legitimados do artigo 103 da Constituição Federal, são os do inciso IX - as confederações sindicais e entidades de classe de âmbito nacional - que mais significativamente representam a sociedade civil (Fernanda Dias Menezes de Almeida e Anna Candida da Cunha Ferraz, $O p$. cit., p.23). No mesmo sentido, Gustavo Binenbojm, A nova Jurisdição Constitucional brasileira: Legitimidade democrática e instrumentos de realização, p.147.
} 
Sobre o tema, o então Ministro Paulo Brossard pronunciou-se no julgamento da ADI $305^{343}$ :

“A Constituição enumerou autoridades e entidades para dar-lhes alta atribuição, que é bem mais política, de interferir para, com a suposta preocupação de sanear o sistema jurídico, eliminar as inconstitucionalidades, por desventura, existentes. E, colocou no mesmo plano o Presidente da República e uma confederação sindical; o Procurador-Geral da República e uma entidade de classe. Parece que se quis servir de entidades não investidas de autoridade, como são." (Grifamos)

Se a Constituição Federal coloca no mesmo patamar todos os legitimados a propor ações no controle concentrado de constitucionalidade, não cabe ao Supremo Tribunal Federal diferenciá-los, especialmente se assim o faz para ir contra os desígnios do próprio texto constitucional. Em verdade, como afirma Gilmar Mendes, trata-se de “inequívoca restrição ao direito de propositura, que, em se tratando de processo de natureza objetiva, dificilmente poderia ser formulada até mesmo pelo legislador ordinário" 344 .

Ao analisar todas as ações diretas de inconstitucionalidade propostas apenas pelas confederações sindicais e entidades de classe de âmbito nacional entre outubro de 1988 e agosto de 2007, Carolina Cutrupi Ferreira constatou que 26\% das 1025 ações foram extintas por ilegitimidade do requerente ${ }^{345}$.

Sendo a necessidade da pertinência temática uma barreira para a admissão desses atores, ela não é o único empecilho por eles encontrados. Como visto, os termos vagos utilizados pelo constituinte ao tratar desses legitimados foram interpretados

\footnotetext{
${ }^{343}$ RTJ 153:431.

${ }^{344}$ Gilmar Ferreira Mendes, Jurisdição Constitucional: O controle abstrato de normas no Brasil e na Alemanha, p.174.

${ }^{345}$ Carolina Cutrupi Ferreira, Op. cit., p.11.
} 
restritivamente pelo Tribunal $^{346}$, que também fixou critérios que dificultam a ampla participação da sociedade ${ }^{347}$.

A respeito dessa questão, o Ministro Gilmar Mendes afirma:

"Ainda que se possa reclamar a fixação de um critério preciso sobre esses conceitos vagos - entidade de classe de âmbito nacional e confederação sindical - , não há dúvida de que eles devem ser fixados pelo legislador e não pelo Tribunal, no exercício de sua atividade jurisdicional. O recurso à analogia aqui é de duvidosa exatidão., ${ }^{348}$ (Grifo original)

De fato, aplicou-se analogicamente a Lei Orgânica dos Partidos Políticos, exigindo-se a representação de entidade em pelo menos nove Estados para reconhecê-la como entidade de classe de âmbito nacional, quando a Constituição não fazia qualquer menção ao uso do mesmo critério.

Acertada, portanto, a conclusão de Gustavo Binenbojm:

“Tal exigência se afigura excessiva e contrária à razoabilidade, uma vez que há inúmeros casos em que a categoria representada pela entidade de classe, embora exibindo vulto e importância nacionais, exerce atividades apenas em alguns Estados da Federação."349

Essa exigência, bem como a de que a entidade de classe deve representar uma única categoria econômica ou profissional, fez também com que uma série de entidades classificadas como de defesa de interesses difusos e coletivos fossem declaradas como ilegítimas para a propositura de ações, como já observado.

\footnotetext{
${ }^{346}$ Nesse sentido, ver Fernanda Dias Menezes de Almeida e Anna Candida da Cunha Ferraz, Op. cit., p.24; Gilmar Ferreira Mendes, Jurisdição Constitucional: O controle abstrato de normas no Brasil e na Alemanha, pp.166-173.

${ }^{347}$ No mesmo sentido, Anna Candida da Cunha Ferraz, "O acesso à Jurisdição Constitucional como caminho para a sua democratização", p.495: "Por outro lado, a interpretação jurisprudencial no tocante à configuração da confederação sindical ou entidade de classe de âmbito nacional, legitimada a exercer o controle jurisdicional tem sido também restritiva, reduzindo a acessibilidade ampla que o texto constitucional parecia conferir a tais entidades."

${ }^{348}$ Gilmar Ferreira Mendes, Op. cit., p.173.

349 Gustavo Binenbojm, A nova Jurisdição Constitucional brasileira: Legitimidade democrática $e$ instrumentos de realização, p.148.
} 
Após uma análise das associações que de fato tiveram sua legitimidade reconhecida pelo STF, pode-se constatar que, com a adoção dessa série de requisitos, exige-se um grau de organização e abrangência tão grande dessas entidades que o acesso da sociedade civil resta limitado a determinadas entidades consagradas socialmente, dotadas de certo poder político-econômico ${ }^{350}$.

Nesse sentido, portanto, corretas as críticas de grande parte da doutrina:

"Perdeu-se boa oportunidade para uma regulamentação mais democrática e menos estreita dos requisitos a serem preenchidos por tais entidades para que elas possam se habilitar à propositura da ação direta de inconstitucionalidade. $\mathrm{O}$ argumento ad terrorem da proliferação incontrolável de causas não pode servir como pretexto para frustrar o acesso de grupos organizados de elevada representatividade social, à participação nos processos constitucionais sobre leis de grande relevância para seus destinos." 351

Há, porém, quem entenda que essa dificuldade encontrada por tais entidades para terem sua legitimidade reconhecida "tem servido para tumultuar ainda mais a já problemática situação do Supremo Tribunal Federal no que concerne à sobrecarga de trabalhos estatísticos", defendendo assim "a supressão do direito de propor ação direta por parte dessas entidades" 352 . É essa a opinião do Ministro Gilmar Mendes, que argumenta que a manutenção dos demais legitimados previstos pela Constituição "já seria suficiente para colocar o nosso sistema entre os mais benevolentes ou liberais no que tange à possibilidade de instauração do controle abstrato de normas" 353 .

\footnotetext{
${ }^{350}$ Como conclui Carolina Cutrupi Ferreira em sua pesquisa, entre as entidades cuja legitimidade é admitida pelo STF predominam associações de trabalhadores ligados ao funcionalismo público - em especial relacionados à atividade jurisdicional - e associações de empregadores, classes que possuem maior poder econômico e político, tendo mais facilidade, portanto, de atenderem os requisitos exigidos pelo Tribunal. (Op. cit., pp.33-34).

351 Gustavo Binenbojm, A nova Jurisdição Constitucional brasileira: Legitimidade democrática e instrumentos de realização, pp.148-149.

352 Gilmar Ferreira Mendes, Jurisdição Constitucional: O controle abstrato de normas no Brasil e na Alemanha, p.175.

${ }^{353}$ Ibidem, p.178. No mesmo sentido, Rogério Bastos Arantes afirma: “Antes restrita ao Procurador-Geral da República, a lista de agentes legitimados a propor ação direta tornou-se uma das mais generosas do mundo, ultrapassando até mesmo os países de modelo puramente concentrado" (Rogério Bastos Arantes,
} 
Com a devida vênia, não parece que a inclusão, pelo constituinte, de tais atores entre os legitimados tenha sido um mero "ato de benevolência". A abertura da jurisdição constitucional à sociedade civil deu-se não só com a ampliação do rol de legitimados, mas também por meio de outros instrumentos - como visto ao longo deste trabalho - e visa especialmente a uma maior proteção da Constituição, bem como a permitir um acréscimo de legitimidade democrática e técnica às decisões do STF.

Além disso, o fato do rol de legitimados previstos no texto constitucional colocar o Brasil entre os mais liberais, no que diz respeito ao acesso ao controle concentrado de constitucionalidade, nada revela sobre nosso grau de democratização. A ideia do constituinte foi democratizar o acesso ao Supremo Tribunal Federal, e, se esse objetivo já encontra dificuldades para ser colocado em prática atualmente, retirar do rol de legitimados aqueles que de fato constituem a sociedade civil só o tornará inviável.

Sem dúvida, uma legislação que regulamente o tema e defina os termos vagos previstos na Constituição de maneira definitiva e menos restritiva - sem deixar tal tarefa a cargo da Corte e suas variações de entendimento - poderá contribuir muito mais com o aumento da participação popular na jurisdição constitucional, sem sobrecarregar o Tribunal com as recorrentes discussões acerca da admissibilidade dessas entidades como legitimadas.

Uma questão processual prevista no Regimento Interno do STF também surge como obstáculo a uma maior participação social:

“Art. 21. São atribuições do Relator:

$[\ldots]$

$\S 1^{\circ}$ Poderá o(a) Relator(a) negar seguimento a pedido ou recurso manifestamente inadmissível, improcedente ou contrário à jurisprudência dominante ou a Súmula do Tribunal, deles não conhecer em caso de incompetência manifesta, encaminhando os autos ao órgão que repute competente, bem como cassar ou reformar, liminarmente, acórdão contrário à orientação firmada nos termos do art. 543-B do Código de Processo Civil."

"Judiciário: entre a Justiça e a Política" in Lúcia Avelar e Antônio Octávio Cintra [org.], Sistema Político Brasileiro: uma introdução, 2. Ed., São Paulo: Unesp, 2007). 
Assim, se a ilegitimidade ad causam de uma entidade já houver sido reconhecida anteriormente pela jurisprudência do Tribunal, o Relator poderá reconhecê-la liminarmente, negando seguimento à ação. Por outro lado, o reconhecimento de sua legitimidade em uma ação não implica a desnecessidade de reafirmá-la em ações posteriores $^{354}$.

Embora o reconhecimento de ilegitimidade pela jurisprudência possa ser alterado, a previsão do artigo supracitado favorece a manutenção dos entendimentos consolidados pela jurisprudência contrários à admissão do autor da ação como legitimado, "exprimindo um caráter conservador do Tribunal quanto ao acesso dos intérpretes constitucionais" 355 .

Essa tentativa do Supremo Tribunal Federal de restringir o acesso à jurisdição constitucional concentrada baseando-se exclusivamente na sua interpretação gerou ainda decisões contraditórias, como destaca Gilmar Mendes:

"O esforço que o Tribunal desenvolve para restringir o direito de propositura dessas entidades não o isenta de dificuldades, levando-o, às vezes, a reconhecer a legitimidade de determinada organização, para negá-la num segundo momento. Foi o que ocorreu com a Federação Nacional das Associações dos Servidores da Justiça do Trabalho, que teve sua legitimidade reconhecida na ADIn 37-3, relativa à Medida Provisória n.44, de 30 de março de 1989, colhendo inclusive a liminar requerida, e, posteriormente, veio a ter a sua legitimidade infirmada nas ADIns 433-6, 526-1 e 530-8." 356

As críticas da doutrina não se limitam, porém, ao esforço do STF em conter a admissão dos legitimados previstos pela Constituição. Nem todas as escolhas feitas pelo constituinte recebem aprovação dos juristas.

O descontentamento dá-se por ter atribuído legitimidade às Mesas do Congresso Nacional e do Poder Legislativo Estadual e Distrital, órgãos que representam a maioria

\footnotetext{
${ }^{354}$ Carolina Cutrupi Ferreira, Op. cit., p.24.

${ }^{355}$ Ibidem, p. 24 .

${ }^{356}$ Gilmar Ferreira Mendes, Jurisdição Constitucional: O controle abstrato de normas no Brasil e na Alemanha, p.173.
} 
parlamentar e que, por isso, dificilmente impugnariam leis aprovadas nos respectivos Parlamentos. Vale mencionar que, de fato, as Mesas do Senado e da Câmara dos Deputados são os legitimados que menos demandaram o STF em sede de controle concentrado de constitucionalidade ${ }^{357}$.

Para Anna Candida da Cunha Ferraz, a decisão do constituinte não sinaliza com a proteção das minorias, razão pela qual propõe:

"Mais salutar seria atribuição, também, da competência a um número fixo de parlamentares, tal como ocorre em outros sistemas de controle, conforme mencionado, até porquanto a atribuição de legitimação aos partidos políticos - relevante embora - não sana, de todo, a lacuna apontada."358

Na concepção de Gilmar Mendes, todavia, a garantia do direito de propositura aos partidos políticos traduz "uma amplíssima compreensão da chamada defesa da minoria no âmbito da jurisdição constitucional", o que não o impede de questionar se não seria mais adequado, "no interesse da preservação da nobreza do instituto do controle abstrato de normas e do bom desempenho da jurisdição constitucional”, conceder tal direito não a eles, mas a um número de deputados ou senadores ${ }^{359}$.

Sob a ótica da proteção às minorias, se a legitimação das Mesas do Congresso Nacional é pouco eficaz, a dos partidos políticos mostra-se mais eficiente, já que basta uma representação singular do partido no Congresso Nacional, como visto ${ }^{360}$. Entretanto, parece que a garantia desse direito a um número determinado de parlamentares - sendo fundamental, porém, que esse número não seja um empecilho para a propositura de

\footnotetext{
${ }^{357}$ De acordo com dados disponíveis em Sociedade Brasileira de Direito Público, Op. cit., p.66 e Eloísa Machado de Almeida, Op. cit., p.29.

358 Anna Candida da Cunha Ferraz, "O acesso à Jurisdição Constitucional como caminho para a sua democratização", p.494.

359 Gilmar Ferreira Mendes, Jurisdição Constitucional: O controle abstrato de normas no Brasil e na Alemanha, p.179. Já Elival da Silva Ramos não fala diretamente na exclusão de legitimados desse rol, mas entende que a ampliação dos legitimados se deu "em termos tão generosos que, talvez, estejam a merecer alguma reformulação de caráter restritivo"(Op. cit., pp.425-426.)

${ }^{360}$ Ver pp.127-128.
} 
ações $^{361}$ - poderia assegurar a mesma proteção, trazendo ainda maior representatividade.

Se há quem defenda que o constituinte poderia ter deixado alguns dos atores de fora do rol do artigo 103 da Constituição, também há quem reivindique a expansão dessa lista.

Para Anna Candida da Cunha Ferraz, seria adequado permitir também a propositura de ações de controle concentrado de constitucionalidade pelo Chefe da Defensoria Pública, o que permitiria "em grau mais elevado e com maior profundidade a defesa de direitos, a defesa do povo em geral ante atos inconstitucionais e, por decorrência, ampliaria a democratização - e a legitimação - da jurisdição constitucional no Brasil”362.

Essa função - de defesa de direitos do povo ante atos inconstitucionais - é, ao que parece, justamente a que cabe a todos àqueles legitimados pela Constituição Federal enquanto atuam no processo de controle abstrato de norma ${ }^{363}$. Se para alguns, porém, o STF passou a exigir a demonstração de interesse próprio - com a criação da pertinência temática - restringindo sua atuação, aos demais ainda cabe essa tarefa, sobretudo ao Procurador-Geral da República, chefe de instituição que visa à defesa do bem-estar da sociedade.

Talvez a simples mudança de interpretação do Supremo Tribunal Federal, dando a todos os legitimados a ampla possibilidade de atuação conferida pelo próprio texto constitucional, já seja suficiente para que a defesa da sociedade contra inconstitucionalidades ocorra em grau mais elevado e com maior profundidade, não sendo assim necessário legitimar novos atores.

\footnotetext{
${ }^{361}$ Na Constituição alemã, por exemplo, exige-se apoio de 1/3 dos membros do Parlamento (art.93, I, n.2). Caso a mesma regra fosse aplicada no Brasil, haveria certamente uma restrição no acesso à jurisdição constitucional concentrada, comparado ao que prevê o atual texto constitucional. Já na Constituição portuguesa, o direito de propositura é conferido a 1/10 dos deputados da Assembleia da República (art.281), enquanto na Constituição da Espanha é necessário o apoio de 50 deputados ou senadores (art.162).

${ }^{362}$ Anna Candida da Cunha Ferraz, "O acesso à Jurisdição Constitucional como caminho para a sua democratização", p.494.

${ }^{363}$ Como explica Gilmar Ferreira Mendes, "os titulares do direito de propositura atuam no processo de controle abstrato de normas no interesse da comunidade ou, se quisermos adotar a formulação de Friesenhahn, atuam como autênticos advogados da Constituição". (Jurisdição Constitucional: O controle abstrato de normas no Brasil e na Alemanha, p.160.)
} 


\subsection{Conclusão}

As mudanças trazidas pela Constituição de 1988 e suas posteriores alterações no sentido de ampliar o rol de legitimados para provocar o controle concentrado de constitucionalidade sem dúvida favoreceram a democratização desta forma de controle.

Enquanto antes se autorizava apenas o Procurador-Geral da República - até então cargo de confiança do Presidente da República - a propor ações de controle de constitucionalidade, com a promulgação da Constituição Federal, em 1988, outros atores passaram a figurar entre aqueles que poderiam impugnar atos normativos diretamente perante o Supremo Tribunal Federal, participando, assim, não apenas manifestando sua opinião, como no caso dos amici curiae e expositores de audiências públicas, mas determinando o que seria discutido e atuando de fato no processo.

Sendo a legitimidade a todo e qualquer cidadão inviável para o processo constitucional por sobrecarregar demasiadamente a Corte, decidiu o constituinte pela legitimação de diferentes órgãos da sociedade que pudessem representá-la. A ampla abertura prevista pelo constituinte igualmente a todos os legitimados, porém, não foi aplicada pelo STF, que, visando restringir o elevado número de ações que passaram a ser propostas, restringiu, sem previsão constitucional, esse direito. Pela via interpretativa, criou verdadeiros obstáculos à participação popular na jurisdição constitucional concentrada.

Com os excessivos requisitos exigidos pelo Tribunal, sobretudo àqueles atores que representam diretamente a sociedade civil, a festejada democratização trazida pela Constituição não se faz mais presente. Se houve avanço com relação ao período anterior a 1988, ele não é tão significativo quanto poderia ser e é menor do que o previsto pelo constituinte.

Nesse sentido, afirma Anna Candida da Cunha Ferraz:

"Não obstante restrita, tal legitimação não é de todo avessa à democratização do exercício do controle concentrado no Brasil, graças à sua atribuição a entidades significativas na proteção de direitos do povo em geral e de direitos fundamentais positivados na Lei Maior às quais o acesso popular, de modo geral, é facilitado. Mas, com certeza pode, sob este 
ângulo, ser aprimorada com a inclusão de novos titulados e de menos restritiva interpretação jurisprudencial.",364

Parece que a simples alteração da interpretação jurisprudencial, deixando de exigir certos requisitos por ela mesma criados, já seria suficiente para ampliar de forma significativa o grau de abertura da jurisdição constitucional concentrada à sociedade.

Como visto, a exigência da pertinência temática, além de alterar a característica do processo $^{365}$, limita consideravelmente a propositura de ações. Não bastasse, os muitos requisitos que devem ser preenchidos para que entidades de classe e confederações sindicais possam ser assim consideradas pelo STF limitam a legitimidade a apenas algumas entidades melhor organizadas e dotadas de poder econômico e político, ficando outras tantas, representativas de diversos segmentos sociais, à margem da jurisdição constitucional concentrada.

Se o acesso possibilitado atualmente coloca o Brasil entre "os mais benevolentes ou liberais no que tange à possibilidade de instauração do controle abstrato de normas" ${ }^{366}$, não é por isso que não há melhorias a serem feitas.

Tendo a ampliação do rol de legitimados previsto na Constituição visado realmente à democratização e a uma maior legitimação das decisões do STF, como se afirma ${ }^{367}$, deveria a Corte ter em mente que "quanto maior, mais significativo e mais representativo da comunidade for o rol de legitimados, e quanto mais aberto a minorias verdadeiramente representativas da sociedade, certamente mais democrático e legítimo será o exercício do controle abstrato e concentrado e mais acessível o exercício do controle jurisdicional de constitucionalidade" ${ }^{\text {368 }}$.

\footnotetext{
${ }^{364}$ Anna Candida da Cunha Ferraz, "O acesso à Jurisdição Constitucional como caminho para a sua democratização", p.496.

${ }^{365}$ Ver pp.134-135.

${ }^{366}$ Gilmar Ferreira Mendes, Jurisdição Constitucional: O controle abstrato de normas no Brasil e na Alemanha, p.178.

${ }^{367}$ Nesse sentido, Elival da Silva Ramos, Op. cit., pp.425-426; Anna Candida da Cunha Ferraz, Op. cit., p.492; entre outros.

${ }^{368}$ Anna Candida da Cunha Ferraz, Op. cit., p.492.
} 
É inegável, portanto, o importante avanço que a Constituição Federal de 1988 deu nesse sentido. Resta agora ao Supremo Tribunal Federal permitir a concretização da abertura da jurisdição à população. 


\section{Conclusão geral}

Como esclarecido desde o início, a proposta deste trabalho é avaliar se e em que medida a previsão das audiências públicas e do amicus curiae e a expansão do rol de legitimados para propor ações de controle concentrado de constitucionalidade correspondem às expectativas dos juristas, de acrescer legitimidade democrática ao Supremo Tribunal Federal.

Para tanto, no primeiro capítulo foram abordados, sucintamente, os questionamentos acerca da legitimidade democrática do controle judicial de constitucionalidade e, no caso brasileiro, do Supremo Tribunal Federal. Como se buscou demonstrar, a questão é ainda controversa, abrindo espaço para que tanto a doutrina quanto a jurisprudência apontem soluções para amenizar esse déficit de legitimidade.

Entre essas soluções, o uso da audiência pública e do amicus curiae e a previsão de um rol mais extenso de legitimados a provocar o controle concentrado de constitucionalidade surgem como os principais caminhos sugeridos.

Para se chegar a uma resposta contundente acerca da contribuição desses mecanismos no acréscimo de legitimidade democrática do STF, realizou-se uma análise do tratamento normativo, da doutrina e da jurisprudência sobre o assunto.

A partir da análise desses três aspectos, procurou-se demonstrar, ao longo deste trabalho, que, do modo como são aplicadas, tais inovações não contribuem tanto quanto poderiam para o acréscimo de legitimidade democrática do Supremo Tribunal Federal.

No caso das audiências públicas, é possível concluir que a escassa regulamentação da matéria associada à alta discricionariedade conferida aos Ministros faz com que cada audiência convocada tenha um perfil, podendo contribuir mais ou menos com o objetivo de democratizar a jurisdição constitucional.

Tendo sido apontados dentre os procedimento utilizados - nas audiências até então realizadas - aqueles que mais contribuem para tal objetivo, entendemos que uma melhor regulamentação do tema - fixando modos de convocação, formas de participação e critérios para escolha de participantes que permitam a pluralização sem, contudo, 
engessar o procedimento - seja a solução para que o instituto, sempre que utilizado e independente de qual Ministro o presida, contribua com a legitimação do STF.

No caso do amicus curiae, a ausência de regulamentação mínima também compromete o melhor aproveitamento do instituto na democratização da jurisdição constitucional. Conforme demonstrado, na prática seu uso pode ou não favorecer o acréscimo de legitimidade democrática, dependendo do entendimento da jurisprudência, que tem sofrido modificações ao longo dos anos.

De um modo geral, os membros do Supremo Tribunal Federal têm, com o tempo, decidido de maneira menos restritiva sobre os poderes processuais dos amici curiae. $\mathrm{O}$ ideal, porém, é que a própria legislação estabeleça tais poderes, para que a utilidade desse instrumento não fique a mercê da boa vontade do Tribunal.

Da mesma forma, os termos vagos utilizados pela lei ao tratar dos requisitos para sua admissão deixam a participação do amicus curiae nas mãos do Relator da ação. Cabe à legislação definir critérios mais objetivos, que permitam uma maior e melhor participação social, sem que os trabalhos do STF sejam comprometidos.

Já no caso dos legitimados a acionar o controle concentrado de constitucionalidade, concluiu-se que o que dificulta uma maior contribuição à participação popular não é a ausência ou vagueza do ordenamento jurídico, já que a Constituição Federal traz um rol amplo de legitimados, mas as restrições criadas exclusivamente pela interpretação feita pelo Supremo Tribunal Federal.

Essa interpretação restritiva cria obstáculos aos legitimados, colocando-os em patamares difererentes, prejudicando justamente a participação daqueles que mais representam a sociedade civil e reduzindo significativamente o amplo acesso previsto pelo constituinte à jurisdição constitucional.

Neste caso, portanto, uma revisão do posicionamento do STF - especialmente com relação à exigência da pertinência temática e outros empecilhos por ele criados - parece ser suficiente para proporcionar uma maior democratização e, consequentemente, acrescer legitimidade democrática às decisões do Tribunal. 
Concluiu-se, com este trabalho, que tais mecanismos podem contribuir com a pluralização da jurisdição constitucional não apenas possibilitando um maior acesso da população à Corte, mas também garantindo uma participação de mais qualidade. Dessa maneira, podem de fato acrescer legitimidade democrática a um órgão como o Supremo Tribunal Federal, cuja legitimação é por vezes questionada. Para tanto, porém, algumas mudanças de regulamentação e de interpretação são necessárias, como se demonstrou ao longo desta dissertação.

Respondida a questão aqui proposta, resta o desafio de compatibilizar a maior participação popular - não só quantitativa, mas também qualitativamente - com a exequibilidade processual e a cada vez mais conturbada agenda do STF. 


\section{Bibliografia}

ALEXY, Robert. "Balancing, constitutional review, and representation". International Journal of Constitutional Law, Vol. 3, N. 4, pp. 572-581, 2005.

"Direitos Fundamentais no Estado Constitucional Democrático: para a relação entre direitos do homem, direitos fundamentais, democracia e jurisdição constitucional". Trad. port. Luís Afonso Heck. Revista de Direito Administrativo, v. 217, p.55-66, jul/set. 1999.

AlmeIDA, Eloísa Machado de. Sociedade civil e democracia: a participação da sociedade civil como amicus curiae no Supremo Tribunal Federal. São Paulo: Tese de Mestrado (Faculdade de Ciências Sociais da Pontifícia Universidade Católica de São Paulo), 2006.

AlmeidA, Fernanda Dias Menezes de, Ferraz, Anna Candida da Cunha. "O constitucionalismo contemporâneo na recente jurisprudência do Supremo Tribunal Federal”. Revista de Direito Constitucional e Internacional, v. 18, n. 71, São Paulo, abr./jun. 2010.

AmARAL JÚNIOR, José Levi Mello do. "Processo constitucional no Brasil: nova composição do STF e mutação constitucional". Revista de Direito Constitucional $e$ Internacional, v. 57, São Paulo, p. 100-108, 2006.

ArAnTES, Rogério Bastos. "Judiciário: entre a Justiça e a Política" in Lúcia Avelar e Antônio Octávio Cintra [org]. Sistema Político Brasileiro: uma introdução. 2. Ed., São Paulo: Unesp, 2007.

Barroso, Luís Roberto. O Controle de Constitucionalidade no Direito Brasileiro. 4. Ed., São Paulo: Saraiva, 2009.

BICKEL, Alexander M. The Least Dangerous Branch: The Supreme Court at the Bar of Politics. 2. New Haven: Yale University Press, 1986. 
BinEnBojM, Gustavo. "A dimensão do amicus curiae no processo constitucional brasileiro: Requisitos, poderes processuais e aplicabilidade no âmbito estadual". Revista Eletrônica de Direito do Estado, n. 1, Instituto de Direito Público da Bahia, Salvador, jan./fev./mar. 2005.

. A nova Jurisdição Constitucional brasileira - Legitimidade democrática e instrumentos de realização. Rio de Janeiro: Renovar, 2010.

Bueno, Cássio Scarpinella. Amicus curiae no processo civil brasileiro: Um terceiro enigmático. São Paulo: Saraiva, 2006.

Bueno Filho, Edgar Silveira. "Amicus Curiae: A Democratização do Debate nos Processos de Controle de Constitucionalidade”, Revista Diálogo Jurídico, $\mathrm{n}^{\circ} 14$, junho/agosto de 2002, disponível na Internet: http://www.direitopublico.com.br.

Cappelletti, Mauro. Giudici Legislatori?, trad. port. de Carlos Alberto Alvaro de Oliveira, Juízes Legisladores?. Porto Alegre: Fabris, 1993.

Costa, Emília Viotti da. O Supremo Tribunal Federal e a construção da cidadania. 2. Ed., São Paulo: UNESP, 2006.

De LaurentiIs, Thais Catib. A caracterização do amicus curiae à luz do Supremo Tribunal Federal. São Paulo: Monografia (Escola de Formação da Sociedade Brasileira de Direito Público), 2007. Disponível em http://www.sbdp.org.br/arquivos/material/298_Monografia\%20Thais\%20Catib\%20$\% 20$ amicus\%20curiae\%20STF.pdf.

DWORKIN, Ronald. Is democracy possible here? - Principles for a new political debate. New Jersey: Princeton University, 2006.

. Taking Rights Seriously. Cambridge: Harvard, 1977.

Ferraz, Anna Candida da Cunha. "A Projeção da Democracia Participativa na Jurisdição Constitucional no Brasil: As Audiências Públicas e sua Adoção no Modelo Concentrado de Constitucionalidade" in Carlos Bastide Horbath, Fernando Dias Menezes de Almeida, José Levi Mello do Amaral Júnior e Roger Stiefelmann Leal 
[coord.], Direito Constitucional, Estado de Direito e Democracia: Homenagem ao Prof. Manoel Gonçalves Ferreira Filho. São Paulo: Quartier Latin, 2011.

- "O acesso à Jurisdição Constitucional como caminho para a sua democratização" in Maria Elizabeth Guimarães Teixeira Rocha, Zilah Maria Callado Fadul Petersen [coord.], Coletânea de Estudos Jurídicos. Brasília: Superior Tribunal Militar, 2008.

"O amicus curiae e a democratização e a legitimação da jurisdição constitucional concentrada" in Revista Mestrado em Direito - Direitos Humanos Fundamentais, ano 8, n. 1. Osasco: Edifieo, 2008.

FERreIRA, Carolina Cutrupi. "Os Critérios de Legitimidade Reconhecidos pelo STF para a Propositura de Ação Direta de Inconstitucionalidade" in Diego R. Coutinho e Adriana M. Vojvodic [coord.], Jurisprudência Constitucional: Como decide o STF? São Paulo: Malheiros, 2009.

FERREIRA FILHO, Manoel Gonçalves. Aspectos do Direito Constitucional Contemporâneo, 2. Ed., São Paulo: Saraiva, 2009.

. Curso de Direito Constitucional, 31. Ed., São Paulo: Saraiva, 2005.

KELSEN, Hans. "Quem deve ser o guardião da Constituição?" in Hans Kelsen, Jurisdição Constitucional. São Paulo: Martins Fontes, 2003.

LEAL, Mônia Clarissa Hennig, MAAs, Rosana Helena. "Audiência pública realizada pelo Supremo Tribunal Federal sobre a lei de biossegurança como forma de ocorrência da figura do amicus curiae”. Revista de Estudos Constitucionais, Hermenêutica e Teoria do Direito (RECHTD), jan./jun. 2010.

LEAL, Roger Stiefelmann. O efeito vinculante na jurisdição constitucional. São Paulo: Saraiva, 2006.

LIMA, Rafael Scavone Bellem de. A Audiência Pública realizada na ADI 3510-0: A organização e o aproveitamento da primeira audiência pública da história do Supremo Tribunal Federal. São Paulo: Monografia (Escola de Formação da Sociedade Brasileira 
de

Direito

Público),

2008.

Disponível

em

http://www.sbdp.org.br/ver_monografia.php?idMono=125

MARTINS, Tahinah Albuquerque. "Audiência Pública na Ação Direta de Inconstitucionalidade 3510/DF: Breves Considerações". Observatório da Jurisdição Constitucional, ano 1, out. 2007. Disponível em: http://www.portaldeperiodicos.idp.edu.br/index.php/observatorio/article/view/87/60

Mattos, Ana Letícia Queiroga de. Amicus curiae: hermenêutica e jurisdição constitucional. Belo Horizonte: Arraes, 2011.

MedeIRos, Fabricio Juliano Mendes. "O Supremo Tribunal Federal e a primeira audiência pública de sua história”. Revista Jurídica, n. 84, v. 9, 2007. Disponível em http://www.planalto.gov.br/ccivil_03/revista/Rev_84/artigos/FabricioJuliano_rev84.htm

MedinA, Damares. Amicus Curiae: Amigo da Corte ou Amigo da Parte? São Paulo: Saraiva, 2010.

Mello Filho, José Celso de. "O Supremo Tribunal Federal e a defesa das liberdades públicas sob a Constituição de 1988: alguns tópicos relevantes" in Alexandre de Moraes [coord.], Os 20 Anos da Constituição da República Federativa do Brasil. Atlas: São Paulo, 2009.

MENDES, Conrado Hübner. Controle de Constitucionalidade e Democracia. 1. Ed., São Paulo e Rio de Janeiro: Campus Elsevier, 2007.

Direitos fundamentais, separação de poderes e deliberação. São Paulo: Tese de doutorado em Ciência Política (Faculdade de Filosofia, Letras e Ciências Humanas da Universidade de São Paulo), 2008.

MENDES, Gilmar Ferreira. "Controle de constitucionalidade: Uma análise das leis 9868/99 e 9882/99”. Revista Diálogo Jurídico, CAJ - Centro de Atualização Jurídica, $\mathrm{n}^{\circ} 11$, Salvador, fev. 2002. Disponível em http://www.direitodoestado.com.br/rede.asp .

Jurisdição Constitucional - O controle abstrato de normas no Brasil e na Alemanha. 5. Ed., São Paulo: Saraiva, 2005. 
Moraes, Alexandre de. Jurisdição Constitucional e Tribunais Constitucionais. 2. Ed., São Paulo: Atlas, 2003.

Nino, Carlos Santiago. Fundamentos de Derecho Constitucional: Análisis filosófico, jurídico y politológico de la práctica constitucional. Buenos Aires: Astrea, 2005.

La constitución de la democracia deliberativa. Barcelona: Gedisa, 1997.

PINTo, Henrique Motta, Rosilho, André Janjácomo. Qual é a função das audiências públicas do STF: a legitimidade democrática ou a legitimidade técnica?. Disponível em http://www.sbdp.org.br/observatorio_ver.php?idConteudo=16

QueIROz NeTo, Luiz Vicente de Medeiros. “A pertinência temática como requisito da legitimidade ativa para o processo objetivo de controle abstrato de normas". Revista da Fundação Escola Superior do Ministério Público do Distrito Federal e Territórios, n. 21, jan./jun. 2003.

RAIS, Diogo. A sociedade e o Supremo Tribunal Federal: o caso das audiências públicas. Belo Horizonte: Fórum, 2012.

Ramos, Elival da Silva. Perspectivas de Evolução do Controle de Constitucionalidade no Brasil. São Paulo: Tese para Concurso de Professor Titular do Departamento de Direito do Estado (Faculdade de Direito da Universidade de São Paulo), 2005.

RochA, Jean Paul C. Veiga da. "Separação dos Poderes e Democracia Deliberativa" in Marcos Nobre e Ricardo Terra [org.], Direito e Democracia: Um guia de leitura de Habermas. São Paulo: Malheiros, 2008.

SAGER, Lawrence G. "Constitutional Justice". New York University Journal of Legislation and Public Policy,n.6, pp.11-19, 2002.

Saldanha, Jânia Maria Lopes, Espindola, Angela Araújo da Silveira. "A jurisdição constitucional e o caso da ADIn 3.510: do modelo individualista - e liberal - ao modelo coletivo - e democrático - de processo". Revista de Processo, n. 154, pp. 265-283, 2007. 
SCHMITT, Carl. O guardião da constituição. Belo Horizonte: Del Rey, 2007.

SILVA, Virgílio Afonso da. "O STF e o Controle de Constitucionalidade: Deliberação, diálogo e razão pública". Revista de Direito Administrativo, v. 250, pp.197-227, 2009.

MENDES, Conrado Hübner. "Habermas e a Jurisdição Constitucional" in Marcos Nobre e Ricardo Terra [org.], Direito e Democracia: Um guia de leitura de Habermas. São Paulo: Malheiros, 2008.

Sociedade Brasileira de Direito Público, Judicialização da política e demandas por juridificação: o Judiciário frente aos outros poderes e frente à sociedade. Belo Horizonte: Faculdade de Filosofia e Ciências Humanas da Universidade Federal de Minas Gerais, 2011.

SuPTITZ, Carolina Elisa, Lopes, Ana Paula de Ameida. "Audiência Pública: Democracia Participativa e Plural?". Anais do XVII Congresso Nacional do CONPEDI, 2008. Disponível em http://www.conpedi.org/manaus/arquivos/anais/brasilia/03_903.pdf

Tavares, André Ramos. Curso de Direito Constitucional. São Paulo: Saraiva, 2002.

TROPER, Michel. "The Logic of Justification of Judicial Review”. International Journal of Constitucional Law, n.1, pp.99-121, 2003.

VALLE, Vanice Regina Lírio do. Audiências públicas e ativismo: diálogo social no STF. Belo Horizonte: Fórum, 2012.

Veríssimo, Marcos Paulo. A judicialização dos conflitos de justiça distributiva no Brasil: O processo judicial no pós-1988. São Paulo: Tese de doutorado (Faculdade de Direito da Universidade de São Paulo), 2006.

VIEIRA, Oscar Vilhena. Supremo Tribunal Federal - Jurisprudência Política. 2. Ed., São Paulo: Malheiros, 2002. . "Supremocracia". Revista Direito GV, São Paulo, pp.441-464, 2008.

WaLDRON, Jeremy. Law and Disagreement. New York: Oxford University Press, 1999. 
. "The Core of the Case Against Judicial Review". The Yale Law Journal, New Haven, v.115, pp.1346-1406, 2006.

. The dignity of legislation. Trad. port. de Luís Carlos Borges, A dignidade da legislação. São Paulo: Martins Fontes, 2003.

WebBer, Jeremy. "Democratic Decision Making as the First Principle of Contemporary Constitutionalism" in Richard Bauman e Tsvi Kahana [org.], The Least Examined Branch: The Role of Legislation in the Constitutional State. Cambridge: Cambridge University Press, 2006. 